Review

\title{
Sustainable Agri-Food Systems: Environment, Economy, Society, and Policy
}

\author{
Hamid El Bilali ${ }^{1, *(D)}$, Carola Strassner ${ }^{2}(\mathbb{D})$ and Tarek Ben Hassen ${ }^{3}(\mathbb{D}$ \\ 1 International Centre for Advanced Mediterranean Agronomic Studies (CIHEAM-Bari), Valenzano, \\ 70010 Bari, Italy \\ 2 Department of Food, Nutrition \& Facilities, FH Münster-University of Applied Sciences, \\ 48149 Munich, Germany; strassner@fh-muenster.de \\ 3 Department of International Affairs, College of Arts and Sciences, Qatar University, Doha 2713, Qatar; \\ thassen@qu.edu.qa \\ * Correspondence: elbilali@iamb.it
}

Citation: El Bilali, H.; Strassner, C.; Ben Hassen, T. Sustainable Agri-Food Systems: Environment, Economy, Society, and Policy. Sustainability 2021, 13, 6260. https://doi.org/10.3390/ su13116260

Academic Editor: Antonino Galati

Received: 1 May 2021

Accepted: 29 May 2021

Published: 1 June 2021

Publisher's Note: MDPI stays neutral with regard to jurisdictional claims in published maps and institutional affiliations.

Copyright: () 2021 by the authors. Licensee MDPI, Basel, Switzerland. This article is an open access article distributed under the terms and conditions of the Creative Commons Attribution (CC BY) license (https:// creativecommons.org/licenses/by/ $4.0 /)$.
Abstract: Agri-food systems (AFS) have been central in the debate on sustainable development. Despite this growing interest in AFS, comprehensive analyses of the scholarly literature are hard to find. Therefore, the present systematic review delineated the contours of this growing research strand and analyzed how it relates to sustainability. A search performed on the Web of Science in January 2020 yielded 1389 documents, and 1289 were selected and underwent bibliometric and topical analyses. The topical analysis was informed by the SAFA (Sustainability Assessment of Food and Agriculture systems) approach of FAO and structured along four dimensions viz. environment, economy, society and culture, and policy and governance. The review shows an increasing interest in AFS with an exponential increase in publications number. However, the study field is northbiased and dominated by researchers and organizations from developed countries. Moreover, the analysis suggests that while environmental aspects are sufficiently addressed, social, economic, and political ones are generally overlooked. The paper ends by providing directions for future research and listing some topics to be integrated into a comprehensive, multidisciplinary agenda addressing the multifaceted (un)sustainability of AFS. It makes the case for adopting a holistic, 4-P (planet, people, profit, policy) approach in agri-food system studies.

Keywords: agriculture; alternative food networks; bibliometrics; culture; diet; food chain; food supply chain; food systems; governance; sustainable development goals; United Nations' Food Systems Summit

\section{Introduction}

Food systems are high on the international agenda, as shown by the United Nations' Food Systems Summit scheduled for September 2021. The Summit is part of the Decade of Action to achieve the Sustainable Development Goals by 2030 and aims to unleash the power of food systems in delivering progress on all SDGs. Indeed, it aims to deliver more sustainable, equitable, and healthier food systems [1] by working on five action tracks viz. ensuring access to safe and nutritious food for all; shifting to sustainable consumption patterns; boosting nature-positive production; advancing equitable livelihoods; and building resilience to vulnerabilities, shocks, and stress [2]. Actors from across the world's food systems will explore how to mobilize key cross-cutting levers of change (e.g., gender, human rights, finance, innovation) to transform agri-food systems towards sustainability. Sustainable food systems (SFS) are also among the key elements of the European Green Deal [3-5] and, more specifically, the Farm to Fork Strategy of the European Union [6,7]. Indeed, the Farm to Fork strategy (F2F) aims at fostering transition towards sustainable, resilient, and inclusive food systems in the European Union [6]. 
According to the High Level Panel of Experts on Food Security and Nutrition (HLPE) of the Committee on World Food Security [8], "A food system gathers all the elements (environment, people, inputs, processes, infrastructures, institutions, etc.) and activities that relate to the production, processing, distribution, preparation and consumption of food and the outputs of these activities, including socio-economic and environmental outcomes". This definition shows that the concept of food systems goes beyond activities (viz. production, processing, distribution, preparation, and consumption) and encompasses other constituent elements as well as the outputs and outcomes of food-related activities. Food systems encompass food supply chains, food environments, consumer behavior, as well as external drivers (e.g., population growth, urbanization, climate change, trade, globalization, politics) and outcomes (environmental, social, economic) [9]. Food systems overlap with agricultural systems in the area of food production, but they comprise the institutions, technologies, and practices that also govern the way food is marketed, processed, transported, accessed, and consumed [10].

Food systems are at the center of various global challenges such as climate change, resource scarcity, and ecosystem degradation [11-14]. Indeed, different socio-economic (e.g., poverty, inadequate diets, hunger and malnutrition, social inequalities) and environmental (e.g., climate change, water scarcity, land degradation, biodiversity loss) challenges are strongly affected by the way food is produced, handled, processed, distributed, prepared, and consumed $[15,16]$. On the one hand, current food systems generate adverse outcomes and, on the other hand, fail to eradicate hunger and malnutrition, especially in the Global South [16-19]. The failures and vulnerabilities of the current global agri-food system have been particularly manifest during the ongoing COVID-19 pandemic [20,21], which affected food supply chains, food environments, and consumption patterns alike [22-25]. While more than enough food is produced [26], the problem of food insecurity persists $[18,27,28]$. Future food systems are called upon to achieve food and nutrition security for all while addressing various sustainability challenges, highlighting the urgency of fostering transition towards sustainable agri-food systems [29].

Conceiving food sustainability includes different aspects, such as sustainable agriculture, sustainable diets, and SFS. Although increased attention is devoted to the concept of SFS, only a few definitions exist [8,30-32]. In this context, the widely used definition of the HLPE [8] indicates that "A sustainable food system (SFS) is a food system that delivers food security and nutrition for all in such a way that the economic, social and environmental bases to generate food security and nutrition for future generations are not compromised" (p. 31). This definition clearly shows the strong link between SFS and food and nutrition security, viz. food insecurity and malnutrition are an outcome of the unsustainability of food systems. SFSs affect and are affected by policies and legal frameworks related to numerous sectors and fields (e.g., environment, agriculture, health and safety, trade, energy) [13].

There is a broad agreement among scholars and practitioners alike that transforming food systems is among the most powerful ways to make progress towards all 17 SDGs [33-36]. Rockström and Sukhdev [37] suggested that food connects all the SDGs and positions them in a hierarchy to be delivered on within a safe operating space for humanity. For instance, the interactions of SDG 2 "Zero hunger" (end hunger, achieve food security and improved nutrition and promote sustainable agriculture) stray into several other SDG areas [38-40]. Indeed, it moves in tandem with SDG 1 (No poverty), SDG 3 (Good health and well-being), and SDG 12 (Responsible consumption and production); but there might be trade-offs with SDG 6 (Clean water and sanitation), SDG 13 (Climate action), SDG 14 (Life below water), and SDG 15 (Life on land) [41]. In this context, Rockström et al. [34] argued that "Without a great Food system transformation, the world will fail to deliver both on the United Nations Sustainable Development Goals and the Paris Climate Agreement" (p. 3).

Despite the growing interest in agri-food systems and their (un)sustainability, there has been, so far, no comprehensive analysis of the scholarly literature in this field. To fill this gap, the present systematic review delineated the contours of the research strand on food systems and analyzed how it relates to sustainability in its environmental, economic, 
social, and political dimensions. The paper also provides an analysis of the bibliographical metrics of the research field.

\section{Methods}

The paper drew upon a systematic review of all documents indexed in the Web of Science (WoS) viz. Science Citation Index Expanded (SCI-Expanded), Arts and Humanities Citation Index (A\&HCI), Social Sciences Citation Index (SSCI), Conference Proceedings Citation Index-Science (CPCI-S), Conference Proceedings Citation Index-Social Sciences and Humanities (CPCI-SSH), and Emerging Sources Citation Index (ESCI). The systematic review followed the PRISMA (Preferred Reporting Items for Systematic Reviews and MetaAnalyses) guidelines [42]. A search was performed on 4 January 2021, using the search query "food system" AND (sustainable OR sustainability), selecting as timespan "all years". The initial literature search on WoS yielded 1389 documents. The selection of the documents included in the systematic review was informed by the methodology suggested by El Bilali $[43,44]$. Table 1 provides details on the selection process steps. In particular, to be considered eligible, documents had to refer to both food systems and (un)sustainability. For the purpose of this article, documents dealing with sustainability in agriculture (viz. crop production, animal husbandry, and fisheries/aquaculture), food supply chains, food value chains, food processing, food distribution, food retail, food preparation, diets, food consumption, nutrition, and/or food waste were considered eligible.

Table 1. Systematic review of food systems in conjunction with sustainability in Web of Science, January 2021: document selection process.

\begin{tabular}{ccc}
\hline Selection Steps & $\begin{array}{c}\text { Number of Selected } \\
\text { Documents }\end{array}$ & Number of Excluded Documents and Exclusion Reasons \\
\hline $\begin{array}{c}\text { Initial search and documents } \\
\text { identification on WoS }\end{array}$ & 1389 & 17 documents excluded because they did not address food systems \\
$\begin{array}{c}\text { Screening of records based on titles } \\
\text { Screening of records }\end{array}$ & 1389 & 12 documents that did not deal with food systems (un)sustainability \\
based on abstracts & 1372 & 39 documents without abstracts (viz. editorial material) \\
Scrutiny of full texts & 1321 & 32 documents excluded because they did not address SFS \\
Inclusion in the systematic review & 1289 & - \\
\hline
\end{tabular}

The screening of titles allowed us to identify 17 ineligible documents that were excluded. An additional 51 documents were excluded following the scrutiny of abstracts. Moreover, 32 documents were discarded following the analysis of full texts. Therefore, 1289 documents were selected for the systematic review (Table A1); these included 1186 journal articles, 100 proceedings papers, and 3 book chapters.

The selected documents underwent both bibliometric and topical analyses. The topical analysis of the selected documents was informed by the SAFA (Sustainability Assessment of Food and Agriculture systems) approach of FAO [45,46]. The SAFA framework has four sustainability dimensions, 21 themes, 58 sub-themes, and 118 indicators. Interestingly, the SAFA framework considers good governance as one of the four dimensions of sustainability for agri-food systems. Themes consist of a set of core sustainability issues. They can be implemented at any level, national, supply chain, or operational unit and thus, provide a common understanding of what "sustainability" means in a practical context. Each sustainability theme is detailed into sub-themes or individual sustainability issues, with associated explicit sustainability objectives (Table 2). 
Table 2. SAFA (Sustainability Assessment of Food and Agriculture systems): dimensions, themes, and sub-themes.

\begin{tabular}{|c|c|c|}
\hline Sustainability Dimension & Themes & Sub-Themes \\
\hline \multirow{7}{*}{ Environmental Integrity (E) } & E1 Atmosphere & E1.1 Greenhouse gases; E1.2 Air quality \\
\hline & E2 Water & E2.1 Water withdrawal; E2.2 Water quality \\
\hline & E3 Land & E3.1 Soil quality; E 3.2 Land degradation \\
\hline & F4 Biodiversity & E4.1 Ecosystem diversity; E4.2 Species diversity; \\
\hline & E4 Biodiversity & E4.3 Genetic diversity \\
\hline & $\begin{array}{l}\text { E5 Materials and } \\
\text { energy }\end{array}$ & $\begin{array}{l}\text { E5.1 Material use; E 5.2 Energy use; E5.3 Waste reduction } \\
\text { and disposal }\end{array}$ \\
\hline & E6 Animal welfare & E6.1 Animal health; E6.2 Freedom from stress \\
\hline \multirow{5}{*}{ Economic Resilience (C) } & C1 Investment & $\begin{array}{l}\text { C1.1 Internal investment; C1.2 Community investment; } \\
\text { C1.3 Long ranging investment; C1.4 Profitability }\end{array}$ \\
\hline & & C2.1 Stability of production; C2.2 Stability of supply; \\
\hline & C2 Vulnerability & $\begin{array}{l}\text { C2.3 Stability of market; C2.4 Liquidity; } \\
\text { C2.5 Risk management }\end{array}$ \\
\hline & & C3.1 Food safety; C3.2 Food quality; \\
\hline & C3 Product quality and information & C3.3 Product Information \\
\hline \multirow{8}{*}{ Social Well-Being (S) } & C4 Local economy & C4.1 Value creation; C4.2 Local procurement \\
\hline & S1 Decent livelihood & $\begin{array}{l}\text { S1.1 Quality of life; S1.2 Capacity development; } \\
\text { S1.3 Fair access to means of production }\end{array}$ \\
\hline & S2 Fair trading practices & S2.1 Responsible buyers; S2.2 Rights of suppliers \\
\hline & & S3.1 Employment relations; S3.2 Forced labor; \\
\hline & S3 Labor rights & $\begin{array}{l}\text { S3.3 Child labor; S3.4 Freedom of association and } \\
\text { right to bargaining }\end{array}$ \\
\hline & S4 Equity & $\begin{array}{l}\text { S4.1 Non-discrimination; S4.2 Gender equality; } \\
\text { S4.3 Support to vulnerable people }\end{array}$ \\
\hline & S5 Human safety and health & S5.1 Workplace safety and health provisions; \\
\hline & S6 Cultural diversity & S6.1 Indigenous knowledge; S6.2 Food sovereignty \\
\hline \multirow{6}{*}{ Good Governance (G) } & G1 Corporate ethics & G1.1 Mission statement; G1.2 Due diligence \\
\hline & G2 Accountability & G2.1 Holistic audits; G2.2 Responsibility; G2.3 Transparency \\
\hline & G3 Participation & $\begin{array}{l}\text { G3.1 Stakeholder dialogue; G3.2 Grievance procedures; } \\
\text { G3.3 Conflict resolution }\end{array}$ \\
\hline & G4 Rule of Law & $\begin{array}{l}\text { G4.1 Legitimacy; G4.2 Remedy, restoration, and prevention; } \\
\text { G4.3 Civic responsibility: G4.4 Resource appropriation }\end{array}$ \\
\hline & G5 Holistic & G5.1 Sustainability management plan; \\
\hline & Management & G5.2 Full-cost accounting \\
\hline
\end{tabular}

Source: Prepared by the authors based on data from FAO [45,46].

Political aspects are included in the governance dimension (cf. policy and governance), while cultural aspects are addressed within the social dimension (cf. society and culture). A search string was developed for each sustainability dimension to perform searches within the selected documents (Table 3). For some differentiated terms we chose the broader non-specific term for full coverage (e.g., air instead of air quality).

This systematic review has some limitations. Firstly, as in any systematic review, the search process affects the results. In particular, the use of the WoS database means that only quality scholarly, peer-reviewed literature was considered (e.g., articles published in journals as well as book chapters and conference proceedings not indexed in WoS and grey literature - such as reports—-were not considered in the present paper). Secondly, the search terms' selection also affects the review results, and this systematic review is no exception in this regard. This applies to the terms used for the initial search, as well as for performing searches within the selected documents. However, different synonyms were utilized to address the different facets of the sustainability dimensions. Moreover, given the high number of documents analyzed, there was a propensity to synthesize and simplify, implying that some sustainability issues were overlooked or not adequately addressed. 
Table 3. Strings used in searches per sustainability dimension within the selected documents.

\begin{tabular}{|c|c|}
\hline Dimension & Search String \\
\hline Environment & $\begin{array}{l}\text { air OR biodiversity OR "climate change" OR ecological OR ecology OR ecosystem OR energy OR environment } \\
\text { OR footprint OR "greenhouse gas" OR land OR material OR pollution OR soil OR waste OR water }\end{array}$ \\
\hline Economy & $\begin{array}{l}\text { business OR competitive OR corporate OR economic OR economy OR employment OR "food access" OR income } \\
\text { OR investment OR livelihood OR market OR poverty OR price OR profit OR "risk management" } \\
\text { OR "value chain" OR "value addition" OR "value creation" }\end{array}$ \\
\hline Society and culture & $\begin{array}{l}\text { civic OR cultural OR culture OR conflict OR discrimination OR equality OR equity OR ethic OR fairness OR } \\
\text { "food safety" OR food sovereignty OR freedom OR gender OR health OR "human safety" OR "indigenous } \\
\text { knowledge" OR justice OR labor OR "life quality" OR lifestyle OR livelihood OR power OR "quality of life" OR } \\
\text { resilience OR resilient OR responsibility OR right OR social OR societal OR society OR "traditional knowledge" } \\
\text { OR vulnerability }\end{array}$ \\
\hline Policy and governance & $\begin{array}{l}\text { agenda OR accountability OR coalition OR collaboration OR cooperation OR governance OR inclusion OR } \\
\text { inclusive OR legitimacy OR "multi-actor" OR "multi-stakeholder" OR participation OR participatory OR plan } \\
\text { OR policy OR politic OR roadmap OR strategy OR transparency OR transparent OR vision }\end{array}$ \\
\hline
\end{tabular}

\section{Results and Discussion}

\subsection{Bibliographical Analysis}

The analysis of the selected documents suggests that research on sustainable food systems is relatively young; the first document that explicitly refers to a "food system" and relates it to sustainability was from Dahlberg [47] and dated back to 1994. The review shows an increasing interest in sustainable food systems with an exponential increase in the number of publications. Indeed, the annual output of documents in the considered period (1994-2020) ranged from nil in 1996 to a maximum of 272 in 2020 (Figure 1). Meanwhile, the average annual output in the period 1994-2020 was about 47 documents. However, the average yearly output has changed markedly from one decade to another; it was just about two in 1995-2000, increased to about 11 in 2001-2010, then increased more than tenfold in the following decade, 2011-2020, to reach about 116 documents per year.

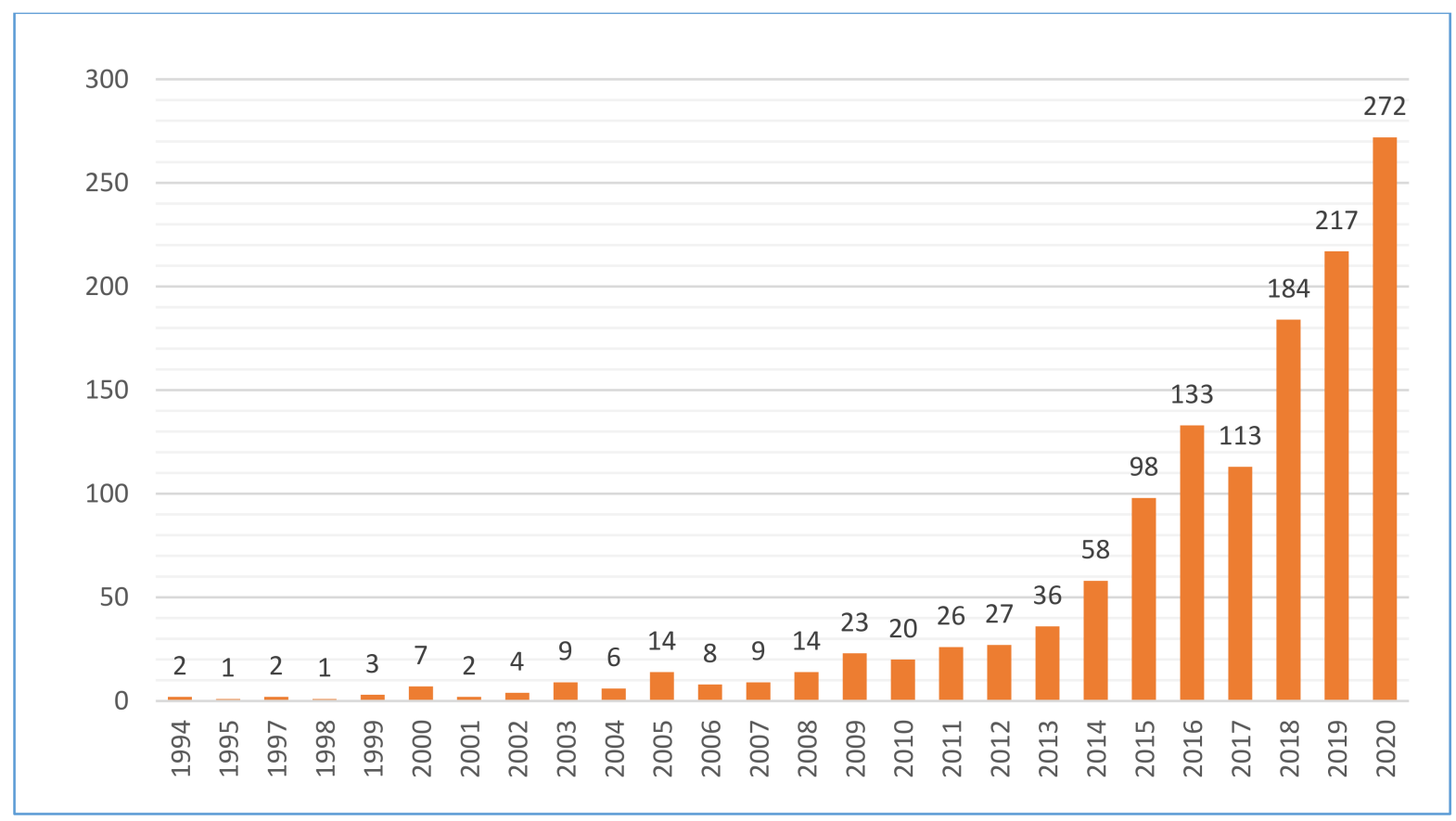

Figure 1. Annual output of documents dealing with sustainable agri-food systems. 
The bibliometrics of the selected documents (e.g., journals, research areas, authors, affiliation institutions, countries, funding agencies, citations) are presented in Tables 4-7.

As for sources, the analysis of the results shows that Sustainability (144 documents, so $11.17 \%$ of the selected ones) is by far the most important outlet for publications on food systems sustainability. Other relevant publication outlets include Agriculture and Human Values (44 documents), Journal of Agriculture, Food Systems and Community Development (37 documents), and Journal of Cleaner Production (36 documents). Nonetheless, the scholarly literature on SFS was published in 468 other journals and sources (e.g., books, conference proceedings). Most of the selected articles can be linked to the research areas of environmental sciences-ecology (455 documents, so $35.3 \%$ of the selected documents), agriculture (320 documents, 24.8\%), and science technology (310 documents, 24.05\%). Further relevant research areas include food science technology (146 documents), nutrition dietetics (119 documents), business economics (105 documents), and geography (103 documents). Nevertheless, the selected documents can be categorized in 65 additional research areas (e.g., engineering, sociology, public administration, development studies, social sciences, urban studies, meteorology-atmospheric sciences, computer science, anthropology, plant sciences, chemistry), which shows that the field is multidisciplinary. Notwithstanding, it can be argued that while environmental and natural sciences are sufficiently addressed, social sciences and, especially, economics and political sciences are generally overlooked (Table 4).

Table 4. Bibliographical metrics: top twenty journals and research areas.

\begin{tabular}{|c|c|}
\hline Journals (a *) & Research Areas (b *) \\
\hline Sustainability (144) & Environmental sciences—Ecology (455) \\
\hline Agriculture and Human Values (44) & Agriculture (320) \\
\hline Journal of Agriculture, Food Systems, and Community Development (37) & Science technology (310) \\
\hline Journal of Cleaner Production (36) & Food science technology (146) \\
\hline Journal of Rural Studies (29) & Nutrition dietetics (119) \\
\hline Agroecology and Sustainable Food Systems (23) & Business economics (105) \\
\hline Food Policy (23) & Geography (103) \\
\hline Frontiers in Sustainable Food Systems (22) & Engineering (82) \\
\hline Renewable Agriculture and Food Systems (20) & Sociology (67) \\
\hline Food Security (18) & Public environmental occupational health (64) \\
\hline International Journal of Environmental Research and Public Health (17) & Public administration (63) \\
\hline Environmental Research Letters (15) & History philosophy of science (57) \\
\hline Public Health Nutrition 15 & Development studies (32) \\
\hline British Food Journal (14) & Social sciences (30) \\
\hline Global Food Security—Agriculture, Policy, Economics, and Environment (14) & Urban studies (30) \\
\hline Ecology and Society (13) & Meteorology-Atmospheric sciences (23) \\
\hline Journal of Agricultural Environmental Ethics (13) & Government law (18) \\
\hline Agriculture Basel (12) & Education-Educational research (15) \\
\hline Global Environmental Change-Human and Policy Dimensions (12) & Computer science (14) \\
\hline $\begin{array}{l}\text { Agronomy for Sustainable Development; Asia Pacific Journal of Clinical } \\
\text { Nutrition; PLOS One; Science of the Total Environment (11) }\end{array}$ & Anthropology (13) \\
\hline
\end{tabular}

\footnotetext{
* Figures in brackets refer to the number of documents by (a) journal and (b) research area.
} 
The bibliometric analysis shows that the most prominent, productive authors are Roberta Sonnino (12 documents); Jessica Fanzo (9 documents); and Imke J. M. De Boer, Hamid El Bilali, Ana Moragues-Faus, and Stephan Rist (8 documents each). However, the 1289 selected documents have been authored by 4079 scholars (so on average more than 3 scholars per document), which shows the dynamism and intensity of collaboration within studies on food systems sustainability. The analysis of countries and affiliations suggests that the study field is north-biased and dominated by researchers and organizations from developed countries. Indeed, the most important affiliation countries are in North America (USA, Canada), Europe (England, Italy, Netherlands, France, Germany, Sweden, Spain, Switzerland, Scotland, Belgium, Finland, Austria, Wales, Norway, Denmark, and Portugal), and Oceania (Australia, New Zealand). Surprisingly, about a third of all selected documents (407 documents, so $31.57 \%$ ) were authored by scholars based in the USA. Interestingly, the top 20 list features some emerging economies, viz. China and Brazil. The only developing countries present in the top 25 list are Kenya and Colombia, which may be due, inter alia, to the presence of some centers of the Consultative Group for International Agricultural Research (CGIAR) in both countries. It comes as no surprise that the most prominent organizations in the research field are based in the Global North, namely Wageningen University Research (The Netherlands), University of California System (USA), and National Research Institute for Agriculture, Food, and the Environment-INRAE (France) (Table 5).

Table 5. Bibliographical metrics: top twenty authors, countries, and affiliations.

\begin{tabular}{|c|c|c|}
\hline Authors (a *) & Affiliation Countries/Territories (b *) & Affiliation Organizations (c*) \\
\hline Sonnino R. (12) & USA (407) & Wageningen University Research (62) \\
\hline Fanzo J. (9) & England (171) & University of California System (50) \\
\hline De Boer I. J. M. (8) & Italy (135) & INRAE (43) \\
\hline El Bilali H. (8) & Canada (117) & CGIAR (33) \\
\hline Moragues-Faus A. (8) & Netherlands (104) & University of Oxford (33) \\
\hline Rist S. (8) & Australia (102) & Cardiff University (24) \\
\hline Béné C. (7) & France (81) & $\begin{array}{c}\text { Commonwealth Scientific Industrial Research } \\
\text { Organisation-CSIRO (24) }\end{array}$ \\
\hline Cordell D. (7) & Germany (68) & University of North Carolina (23) \\
\hline Eakin H. (7) & Sweden (62) & Michigan State University (20) \\
\hline Garnett T. (7) & Spain (50) & Stockholm University (20) \\
\hline Godfray H. C. J. (7) & Switzerland (50) & Swedish University of Agricultural Sciences (20) \\
\hline Ahmed S. (6) & China (40) & University of Minnesota System (20) \\
\hline Allen P. (6) & Scotland (35) & University of Minnesota Twin Cities (20) \\
\hline Brunori G. (6) & Belgium (34) & ETH Zurich (18) \\
\hline Galli F. (6) & Finland (34) & Agroparistech (17) \\
\hline Ingram J. (6) & Austria (31) & Cornell University (17) \\
\hline Klerkx L. (6) & Wales (30) & University of California Davis (17) \\
\hline Lang T. (6) & Norway (26) & University of London (17) \\
\hline Milestad R. (6) & South Africa (26) & City University London (16) \\
\hline $\begin{array}{l}\text { Pereira L. M., Peters C. J., Roos E., } \\
\text { Smith P. (6) }\end{array}$ & Brazil, Denmark (25) & $\begin{array}{c}\text { University of Bodenkultur Wien (BOKU); } \\
\text { University of Edinburgh (16) }\end{array}$ \\
\hline
\end{tabular}

* Figures in brackets refer to the number of documents by (a) author, (b) country/territory, or (c) organization. 
One reason for the north bias might be the funding of the research field. Indeed, the most important funding agencies are based in developed countries and regions (Table 6), namely the European Commission, UK Research Innovation-UKRI, National Science Foundation-NSF (USA), and Natural Environment Research Council-NERC (UK). However, it should be pointed out that the list of the top 20 funding agencies features some international organizations (CGIAR), funding organizations from emerging countries (National Natural Science Foundation of China-NSFC), as well as some philanthropic organizations (Wellcome Trust).

Table 6. Bibliographical metrics: top twenty funding agencies.

\begin{tabular}{|c|c|}
\hline Funding Agencies & Number of Funded Studies \\
\hline European Commission & 74 \\
\hline UK Research Innovation-UKRI & 47 \\
\hline National Science Foundation-NSF (USA) & 39 \\
\hline Natural Environment Research Council-NERC (UK) & 22 \\
\hline CGIAR & 21 \\
\hline National Natural Science Foundation of China-NSFC & 18 \\
\hline Social Sciences and Humanities Research Council of Canada-SSHRC & 17 \\
\hline United States Department of Agriculture-USDA & 16 \\
\hline Economic Social Research Council-ESRC (UK) & 15 \\
\hline French National Research Agency_ANR & 10 \\
\hline Natural Sciences and Engineering Research Council of Canada-NSERC & 10 \\
\hline Swiss National Science Foundation-SNSF & 10 \\
\hline Australian Research Council & 9 \\
\hline Biotechnology and Biological Sciences Research Council-BBSRC (UK) & 9 \\
\hline Engineering Physical Sciences Research Council-EPSRC (UK) & 9 \\
\hline Federal Ministry of Education Research—BMBF (Germany) & 9 \\
\hline European Research Council-ERC & 8 \\
\hline Ministry of Education, Culture, Sports, Science and Technology Japan-MEXT & 8 \\
\hline Spanish Government & 8 \\
\hline Swedish Research Council FORMAS, Wellcome Trust & 8 \\
\hline
\end{tabular}

As per the number of citations, the most influential and widely used documents in the research field are Food Security: The Challenge of Feeding 9 Billion People [48], Comparing the yields of organic and conventional agriculture [49], and Embeddedness and local food systems: notes on two types of direct agricultural market [50] (Table 7). 
Table 7. Citation report: top ten publications.

\begin{tabular}{|c|c|c|c|c|}
\hline Document Title & $\begin{array}{l}\text { Publication } \\
\text { Year }\end{array}$ & Reference & $\begin{array}{l}\text { Total } \\
\text { Citations }\end{array}$ & Average per Year \\
\hline $\begin{array}{l}\text { Food Security: The Challenge of Feeding } \\
9 \text { Billion People }\end{array}$ & 2010 & Godfray et al. [48] & 4853 & 404.42 \\
\hline $\begin{array}{l}\text { Comparing the yields of organic } \\
\text { and conventional agriculture }\end{array}$ & 2012 & Seufert et al. [49] & 782 & 78.2 \\
\hline $\begin{array}{l}\text { Embeddedness and local food systems: notes on } \\
\text { two types of direct agricultural market }\end{array}$ & 2000 & Hinrichs [50] & 677 & 30.77 \\
\hline $\begin{array}{l}\text { Should we go home to eat?: toward a reflexive } \\
\text { politics of localism }\end{array}$ & 2005 & DuPuis and Goodman [51] & 567 & 33.35 \\
\hline $\begin{array}{l}\text { Sustainability of meat-based and plant-based } \\
\text { diets and the environment }\end{array}$ & 2003 & Pimentel and Pimentel [52] & 465 & 24.47 \\
\hline $\begin{array}{l}\text { Where are the best opportunities for reducing } \\
\text { greenhouse gas emissions in the food system } \\
\text { (including the food chain)? }\end{array}$ & 2011 & Garnett [53] & 449 & 40.82 \\
\hline $\begin{array}{l}\text { Biomass use, production, feed efficiencies, } \\
\text { and greenhouse gas emissions from global } \\
\text { livestock systems }\end{array}$ & 2013 & Herrero et al. [54] & 439 & 48.78 \\
\hline Food security and sustainable intensification & 2014 & Godfray and Garnett [55] & 384 & 48 \\
\hline $\begin{array}{l}\text { Shifting plates in the agrifood landscape: } \\
\text { the tectonics of alternative agrifood } \\
\text { initiatives in California }\end{array}$ & 2003 & Allen et al. [56] & 383 & 20.16 \\
\hline $\begin{array}{l}\text { Agroecology as a science, a movement } \\
\text { and a practice. A review }\end{array}$ & 2009 & Wezel et al. [57] & 353 & 27.15 \\
\hline
\end{tabular}

\subsection{Topical Analysis}

\subsubsection{Environment}

Out of the 1289 selected documents, 984 (so 76.3\%) addressed issues relating to the environmental sustainability of the agri-food systems. These ranged from the use of resources in agriculture and the food sector, to relations between the agri-food systems and biodiversity or climate change, as well as the pressure of agri-food systems on ecosystems (cf. footprints).

Many scholars highlighted that the operation of food systems should take place within planetary boundaries and safe operating space for humanity [58-65]. For instance, Galli et al. [58] argued that "The food system is increasingly acknowledged as the single largest reason for humans' transgression of key planetary limits and it is gaining centrality in our societal runup towards a sustainable future". While some articles addressed the whole food system or agricultural sector, some focused on single sub-sectors, such as animal husbandry [62,66-74], which is widely blamed for environmental and ecosystem disturbance.

The way resources are used is central in determining the environmental sustainability of agri-food systems. These resources include water [75-79]; land [80-84]; nutrients e.g., phosphorus [59,85-88], nitrogen [60,89-92], and potassium [93]; and energy [75,76,94-96]. In this regard, particular attention has also been paid to circularity/circular economy [72,97-100] and managing food losses and waste [101-105]. Some articles have taken a broader perspective and addressed different types of nexuses, such as water — energy—-food [75,76,106-113], waterenergy — food — climate [114], water — energy — biodiversity [115], water-land —energy [116], or water-land - energy—nutrients [117]. One way to cope with the increasing scarcity, and even depletion, of resources is to increase their use efficiency [73,87,118-120]. However, such increases can lead to agricultural intensification, the concept of which is a matter of huge debate among supporters and opponents [121,122]. Indeed, while some scholars highlight the benefits of "sustainable intensification" [55,121,123-125], others are rather critical and point out that 
"intensification" and "sustainability" are rather two contradictory words, such that intensification can hardly be qualified as sustainable [121-123]. In this regard, Godfray [121] pointed out that "there are worries that it might be used to justify intensification per se and the accelerated adoption of particular forms of high-input and hi-tech agriculture" (p. 199).

Agri-food systems have different footprints on ecosystems (both natural and agroecosystems) and natural resources, such as ecological footprints [58,126-131], nitrogen footprints [60,126], carbon footprints [126-128,132-139], water footprints [108,126-128,140-142], and energy footprints $[96,134]$. The concept of a carbon footprint is linked to that of "food miles" [143-148] and is among the reasons put forward to highlight the benefits of localized, short food supply chains (SFSC) [128,148-151] and alternative food networks (AFN) [146,152-155]. Similarly, the concept of a water footprint is related to that of "virtual water" [142,156,157], and trade of agri-food products (thus also water embedded in them) [156] can help cope with water scarcity in some countries, especially those with an arid climate. As for water resource management, besides excessive water withdrawal and use [157-159], issues relating to water quality [158-160] are also addressed.

Climate change is a recurrent topic in the literature on agri-food system (un)sustainability [161-167]. The literature highlights the dual relationship between agri-food systems and climate change. In fact, agri-food systems are, on the one hand, among the main contributors to climate change through greenhouse gas (GHG) emissions [102,137,166,168,169] and, on the other hand, highly affected by climate change $[162,164,166]$. The existing literature has dealt with both climate change mitigation [162,166,168,170,171] and adaptation [164,172,173]. In this regard, some scholars have highlighted the benefits of climate-smart agriculture [172,174], which has been put forward to address concurrently three challenges: climate change mitigation, climate change adaptation, and global food security [172].

Biodiversity is another central theme in the literature on agri-food system sustainability. Indeed, agri-food systems contribute to biodiversity loss [175-179] through, among other factors, changes in land use (cf. deforestation) and habitat destruction, land degradation, and pollution caused by intensive agriculture that leads to some phenomena such as eutrophication in water bodies. Campbell [175] argued that "The food system is the biggest user and polluter of land and water, the biggest driver of habitat and biodiversity loss, and on track to be the biggest emitter of greenhouse gases" (p. 261). Agri-food systems have affected not only genetic diversity (of plant and animal species alike) $[180,181]$ but also landscape diversity [182]. Moreover, there is also an ongoing reduction of the number of plants consumed with the erosion of dietary diversity [183-186] and local knowledge associated with these neglected orphan crops [187-189].

Some articles have addressed environmentally friendly agricultural systems such as organic farming [190-194] and agro-ecology [190,195,196], biodynamic agriculture [197,198], and conservation agriculture [199]. Migliorini and Wezel [190] suggested that "Both agroecology and organic agriculture offer promising contributions for the future development of sustainable agricultural production and food systems, especially if their principles and practices converge to a transformative approach and that impedes the conventionalisation of agro-food systems". Indeed, agro-ecology is considered by many scholars not only as a system to make agriculture more sustainable but also to bring about the transition to sustainable agri-food systems [200-202]. Gliessman [201] stated that "Agroecology focuses on the entire food system, from the seed to the table". The benefits of agro-ecology are not only environmental/ecological but also social and economic, especially for small-scale farmers [202].

Many scholars have called for adopting more sustainable, plant-based diets [60,203-206] to reduce the environmental impacts of the current food systems. These include examples such as the Mediterranean diet [206,207], vegetarian diets [60,208-210], and the vegan diet [211]. However, Forber et al. [86] warned that the adoption of plant-based diets (e.g., vegan, flexitarian) might add to the wastewater phosphorus burden in the UK. This example shows that the adoption of plant-based diets is not a panacea and can have some environmental trade-offs. 


\subsubsection{Economy}

Out of the selected documents, 748 (so 58\%) addressed economic issues in agriculture and food systems. The agriculture and food economy is vital in the livelihoods of millions of people, both in rural and urban areas [212-214]. Indeed, the agri-food sector is a lever for reducing poverty and vulnerability. This makes the case for increasing sustainable, green investments in the agri-food sector $[164,215,216]$. Nevertheless, food poverty is still widespread even in developed countries [217-219]. Therefore, referring to the lessons learned from the COVID-19 pandemic in poor areas, Bounie et al. [220] stated that "There needs to be a move beyond rehabilitating and increasing agricultural production to addressing the whole food system with a view to link humanitarian assistance and longer-term support to sustainable livelihoods and resilience" (p. 367). Moreover, rural livelihoods need to adapt and become more resilient to the changing climate [213].

Apart from their environmental benefits (cf. fewer food miles, lower carbon footprint), another reason for pushing forward local, short food supply chains is their contribution to regional, local economies $[149,221-227]$. This happens, inter alia, through the creation of jobs [223]. For instance, Derunova et al. [228] saw the inclusive development of the agrifood system as a driver for sustained growth in the Russian regional economy. However, Jongerden et al. [229] pointed out that "Even though local policymakers, the international community, and the international organisations emphasise the potential of agriculture for food production, job creation, and income generation, they also tend to consider the current food system problematic because of an alleged low productivity", especially in developing countries. Referring to SFSCs in Quebec (Canada), Mundler and Laughrea [223] highlighted that "The most positive aspects of these systems are job creation, skills development for farmers, job satisfaction, and the adoption of sustainable agricultural practices" (p. 218). This clearly shows that the economic impacts of SFSCs in particular, and agriculture and food systems in general, are context-specific and vary among countries/territories. Other articles have dealt with the relations between agri-food systems and innovative economic models, such as circular economies [35,100,222,230-232], green economies [233], and bio-economies [234].

Markets are a central theme in addressing the economic sustainability of agri-food systems [235-237]. While some scholars have highlighted the positive roles of markets [236,238], especially concerning food access, others have seen markets as one of the main drivers of the unsustainability of agriculture and food systems $[236,239,240]$ through processes such as commodification [241]. These different opinions about markets and their role in agri-food systems can be due, among other reasons, to the framing of food as "commons" or as "commodity" [242-244]. Some inappropriate market and trade practices have led to the promotion of alternative supply chains such as Fairtrade $[245,246]$. Moreover, it is essential to highlight that markets are not alike and range from "corporate" markets to more inclusive, democratic ones, such as farmers' markets [50,150,247-249] and community markets [151]. However, Hinrichs [50] argues that "In providing an alternative market, farmers' markets create a context for closer social ties between farmers and consumers, but remain fundamentally rooted in commodity relations" (p. 295).

The economic sustainability of the agri-food system is also addressed in relation to food accessibility and affordability $[240,250,251]$, which are related to the level of prices of agri-food products as well as their volatility [251,252]. What is alarming is that the increase in food prices might induce many people to substitute nutritious, fresh food with carbohydrates and sugar, which has detrimental health impacts (cf. obesity, diabetes, cardiovascular diseases, cancer) [174], with a consequent increase in public health costs. In this respect, Drewnowski et al. [253] suggested that "Food systems may need to be restructured to ensure that the global food supply provides adequate calories and nutrients at an affordable cost" (p. 1). Elmes [240] argues that "Unequal access to nutritious foods in the United States is attributable in part to an industrial food system that is designed to produce short-term profits for industrial food producers, processors, and distributors that extract surplus labor value through market concentration and opportunistic behavior at the expense of the long-term benefits for consumers, food workers (including farmers), and ecosystems" (p. 1045). 
While the concept of price is central in the literature on the economics of agri-food systems, more and more scholars have drawn attention to that of cost and, especially, "full cost" [252,254] or "real cost" [255]. This allows bridging the gap between economic reasoning and other dimensions of sustainability, such as the environment and health. For instance, the concept of "full cost" has been used in relation to "food miles" [254]. Other authors refer to "energy cost" [256,257], "environmental cost" [144,258-260], and "nitrogen cost" [89]. Coveney [258] underlined that "Many have argued that environmental costs of food production are hardly ever factored into the profitability equation" (p. 97), which highlights the need for internalizing these costs to get an accurate idea about the real, full cost of food.

\subsubsection{Society and Culture}

Social and cultural issues are generally overlooked in the literature on agri-food system (un)sustainability. In fact, 737 (so $57.2 \%$ ) addressed issues relating to society and culture in agri-food systems out of the selected documents.

Many articles referred to "food justice" [261-267] or "food dignity" [268,269]. Food justice is an evolving concept that puts social justice at the center of the debate on achieving sustainable food systems [264]. The concept of justice is similar to fairness, which is associated with many alternative food networks and supply chains such as Fairtrade $[245,246]$. Other scholars addressed the concepts of "food democracy" [261,262,268,270-276] or "food sovereignty" [261,277-283], which are strongly linked to the way the food system is governed and managed and the inclusion of the different concerned stakeholders in the process of decision making about the future of agri-food systems, especially at the local level. Food democracy is a process that puts people at the center of and gives them a voice in and control over the transition towards more sustainable agri-food systems [270,271]. Baldy and Kruse [271] recognized eight central elements in the concept of food democracy: transparent ideas deliberation processes, mutual knowledge exchange, credibility and legitimacy of knowledge claims, shared language, raising awareness, experience with and expectations of efficacy, role model function of municipalities, and justification and motivation of the normative orientation. These justice-oriented concepts are strongly related to the concept of power; indeed, many scholars consider power imbalances one of the most critical issues in the current agri-food systems [262,264,284,285]. Democratizing the food system is, at the same time, an outcome of and a prerequisite for the empowerment of the different actors involved [274]. Despite the increasing interests in these social aspects of the agri-food systems, referring to urban food strategies (UFSs) in Europe, Smaal et al. [261] found that "UFSs make little explicit reference to social justice and justice-oriented food concepts, such as food security, food justice, food democracy and food sovereignty".

The scholarly literature has also addressed human rights in relation to agri-food systems [286-289]. For instance, Anderson [286] argued that "Food security, health, decent livelihoods, gender equity, safe working conditions, cultural identity and participation in cultural life are basic human rights that can be achieved at least in part through the food system" (p. 593) and coined the new concept of "rights-based food systems". Human rights also relate to labor as they imply decent working conditions and jobs [290]. In particular, the "right to food" is a prominent topic in the literature dealing with eradicating hunger and the achievement of food security [284,287,291,292].

The scholarship on the sustainability of agri-food systems has also addressed several ethical issues [293-300], such as animal welfare [55,294,301,302] or those relating to the use of biotechnologies [303]. Allievi et al. [293] went even farther and made a strong case for considering "ethics" as the fourth dimension of sustainability. Other scholars referred to moral issues [299,304-306]. In this respect, Reuter [304] argued that greater attention to the moral dimension of food systems will contribute to more successful food security and agricultural development programs. Likewise, Bui et al. [297] identified inclusive governance and "systemic ethics" (i.e., relating to a systemic understanding of sustainability, including social justice) as key features for initiatives contributing to sustainability transitions in agri-food systems. 
The literature has also dealt with gender issues from different perspectives [174,307-310]. While women play an essential role in the agri-food system, they generally have less power and representation in decision-making processes [307]. Most articles focused on women, but some addressed specific gender categories such as lesbians [308]. Some scholars went a step farther and analyzed social classes and race issues in agri-food systems [267,311]. Nevertheless, the studies on racism and racial issues have mainly come from the US.

Some scholars have called for paying more attention to the relations between agri-food systems, especially diets, and health [253,312-315]. This is done, among other ways, by operationalizing the holistic and systemic concept of "One Health" [24,316,317], which relates the health of humans with that of animals and ecosystems/environment. Such a call, particularly timely and relevant in the current context of the COVID-19 pandemic, which affected different components of the agri-food system, such as agricultural production, food distribution, and food consumption and dietary patterns [20,24,98,318-321], carries implications in terms of food and nutrition security [24,320]. In this regard, referring to nutrition research in the US, Fleischhacker et al. [320] argued that "The coronavirus disease 2019 (COVID-19) outbreak has further laid bare these strains, including food insecurity, major dietrelated comorbidities for poor outcomes from COVID-19 such as diabetes, hypertension, and obesity, and insufficient surveillance on and coordination of our food system" (p 721). The focus on health is also related to food safety, which is fairly addressed in the analyzed literature [322-330], especially concerning foodborne diseases [329].

Different components of culture have been addressed in the literature on food system sustainability. These include food culture [266,331,332] and culinary culture [333]. In this respect, many scholars have referred to indigenous, traditional knowledge [188,334,335] and highlighted that its erosion is jeopardizing the sustainability of local diets, as well as the traditions associated with them. Wahlqvist and Lee [331] warned that "There has been a recent awakening of interest and concern about the lack of documentation of traditional and indigenous food cultures which are important not only for their own sake, but for the legacy of food knowledge which they can confer on future generations, provided they are not lost" (p. 2).

Social and cultural issues also play a central role in the transition towards more sustainable diets and food systems. In fact, there have been many attempts to suggest alternative foods, which are more sustainable, but their success also depends on their social and cultural acceptance by consumers [336-338]. Many articles have addressed consumers' attitudes towards alternative products-mainly as alternative sources of proteins-such as pulses [338,339] and insects [336].

\subsubsection{Policy and Governance}

Policy and governance are largely overlooked in the literature on agri-food system (un)sustainability. As a matter of fact, only 424 (so 32.9\%) addressed political and governance issues out of the selected documents.

Articles dealing with policies in the agri-food systems either analyzed the current state of play or focused on policies needed to foster transitions towards sustainable agri-food systems at different levels e.g., regional (European Union), national (e.g., Australia, Belgium, Brazil, Canada, Finland, France, Germany, Italy, Japan, The Netherlands, New Zealand, Norway, Portugal, Sweden, Switzerland, USA), or local (e.g., city, city-region, etc.). In this context, more and more studies have dealt with urban food systems and their transition towards sustainability [261,340-347]. However, the empirical findings of Doernberg et al. [341] from German cities showed that "urban food policy activities are still very fragmented and often based on individual initiatives", as well as the lack of "integrated urban food policies and their implementation through urban food strategies". They also found that the capacities of municipal actors for policy implementation remain limited due to missing financial and staffing resources. Most studies on urban food systems have focused on developed and industrialized countries. Meanwhile, different types of policy documents have been analyzed e.g., strategies [261,341,348-352], action plans [349], agendas [353], guidelines [354-356], standards [357], etc. The analyzed policies and policy documents deal, inter alia, with food 
and nutrition security $[235,349,350,358,359]$, sustainable and healthy diets [354,360,361], non-communicable diseases [354,362], biodiversity [349,363], organic farming [364], etc. Examples include the Common Agricultural Policy (CAP) [365,366], The European Food and Nutrition Action Plan 2015-2020 [367], the Milan Urban Food Policy Pact [342], Nepal's Multisectoral Nutrition Plan (MSNP) 2013-2017 [349], Healthy food and beverage policy of the City of Hamilton (Ontario, Canada) [360], the Good Food Purchasing Policy (GFPP) in Los Angeles (USA) [368], the Local Food Strategy of Ghent (Belgium) [351]. Particular attention has also been paid to the linkages between sustainability transitions in agri-food systems and the achievement of the SDGs, especially SDG 2 "Zero Hunger" [35,36,369-374]. Other articles have addressed synergies and/or trade-offs between policies and their instruments [312,375,376].

Papers addressing governance focused mainly on the local urban level. In fact, many multi-stakeholder mechanisms (that involved actors from the public, private, and civil society realms), aiming at improving the governance of local and city-region food systems, have been analyzed in the literature. These multi-stakeholder groups include food (policy) councils [274,368,377-382], networks [281,344,383], and partnerships [384,385]. The innovative governance mechanisms allow increasing the participation and inclusion of stakeholders in managing food systems, thus democratizing it [261,262,268,270-276]. In this regard, Béné et al. [386] suggested that "To operationalize the great food system transformation and ensure its sustainability, five areas of research and action require more attention: economic and structural costs; political economy; diversity of cultural norms; equity and social justice; and governance and decision support tools". The active involvement of consumers in the governance of the food system means "moving from consumer to food citizen" [387]. Wilkins [387] put that "The term food citizenship is defined as the practice of engaging in foodrelated behaviors that support, rather than threaten, the development of a democratic, socially and economically just, and environmentally sustainable food system" (p. 269). The evolution of the framing of food issues and the adoption of more systemic approaches in dealing with food led to the emergence of innovative governance models such as "inclusive governance" [297] and "reflexive governance" [298,358]. The new governance arrangements also give rise to an increase in the control of local communities over their own food systems and the emergence of concepts such as food sovereignty [261,277-283]. Different models of agriculture and food systems emphasize the role of the community and the importance of its active participation, such as community-supported agriculture [263,388-397], community gardens [218,390,398-400], community seed banks [196], community kitchens [390], and community-based fisheries [401]. This focus on participation led to the emergence of different participatory approaches that do not only cover the whole food chain (from production to consumption), but also associated activities such as participatory research [290,402-405], participatory breeding [307,406], and participatory certification [407,408]. Besides participation and inclusiveness, accountability [409,410] and transparency [301,411,412] are central in the new governance arrangements for sustainable agri-food systems.

\section{Conclusions}

A growing body of evidence shows that the world today is not on track towards achieving SDG 2 i.e., ending hunger, food insecurity, and malnutrition in all its forms by 2030. Getting on track towards achieving SDG 2 will necessitate a move away from silo solutions towards holistic, integrated solutions that address the global food security and nutrition challenges. Agri-food systems are failing to ensure nutritious and affordable foods, and this is made more difficult in the context of the COVID-19 pandemic. However, if food systems are transformed with improved sustainability and strengthened resilience, they can put humanity on track towards achieving SDG 2 . This makes the case for paying more attention to agri-food systems and their (un)sustainability. In this context, the present paper is, to the best of our knowledge, the first that provides a comprehensive overview of the literature dealing with agri-food systems and their relation to sustainability in its 
environmental, economic, social, and political dimensions. It also provides an analysis of the bibliometrics of the study field.

The review shows an increasing interest in sustainable food systems with an exponential increase in the number of publications over the last decade. However, the study field is north-biased and dominated by researchers and organizations from developed, industrialized countries (e.g., USA, UK, Italy, Canada, The Netherlands, and Australia). Moreover, the analysis suggests that while environmental and natural sciences are sufficiently addressed, social sciences, economics, and political sciences are generally overlooked. However, sustainability dimensions are not mutually exclusive, and most studies addressed more than one dimension.

Accordingly, the paper highlights the need to pay more attention to social issues (e.g., equity, social justice, human rights, ethics, and power) and politics and governance in studies on agri-food systems sustainability. It also suggests the need to address the tradeoffs between the different sustainability dimensions. This implies a closer integration between different disciplines, such as natural, social, economic, and political sciences, to better reflect the complexity of contemporary food systems and respond to demands for change from different societal groups and stakeholders. This, in turn, means a shift from linear approaches towards a more interlinked, nested analysis of agri-food system drivers, processes and dynamics, and outcomes. While the focus on understanding the flaws and shortcomings of the current agri-food systems is still needed, the scholarship must devote more attention to identifying instruments and tools to bring about the needed transition towards sustainable agri-food systems. Future systematic reviews on sustainability in agri-food systems could also benefit from a graphical analysis allowing for a network visualization map of the linkages among sustainability dimensions and themes.

Similarly, while the term "food system" is nowadays widely used (as shown by the high number of documents included in this review), the components of and activities within food systems are often analyzed separately, which highlights the need for more integration of "systems science" in studies on agri-food systems sustainability. It is also crucial to strengthen the science-policy interface for improved food system governance. In this context, the paper makes the case for adopting a holistic, 4-P (planet, people, profit, policy) approach in food system studies. Such an approach should combine retrospective studies that focused on causes, sources of pressure, and drivers; present-day studies that have addressed sustainability assessments in different realms of the food system; and prospective studies that envision the future of food systems and advise measures and strategies to foster transitions towards more sustainable agri-food systems. In this respect, the following research areas seem particularly relevant: conceptualization, design, and operationalization of SFS at different levels (global, regional, national, local); methods, approaches, and models for the assessment of agri-food sustainability; sustainability transitions in AFS; new generation of food policies and governance models for SFS; food systems in the context of the SDGs; effects of the COVID-19 pandemic on the functioning, performance, and resilience of AFS.

Achieving agri-food system sustainability is one of the pressing challenges of this century. Addressing this challenge requires drawing upon knowledge and expertise from diverse disciplines and intellectual traditions to document the challenges and critical threats to food system sustainability and define an appropriate agenda for research, policy, and action. In fact, it is crucial to develop a common understanding, framing, and vision on aspects of the agri-food system that are threatened and the system features, attributes, and functions that must be relinquished, sustained, or restored. The present paper contributes to this undertaking by synthesizing scholarly literature on agri-food system (un)sustainability. Furthermore, the insights provided by the paper inform not only policy on sustainable food systems but also the upcoming UN Food Systems Summit to bring about the necessary transition to sustainable food systems and unlock the potential of food systems in the post-COVID-19 pandemic recovery and the achievement of the SDGs. 
Author Contributions: Conceptualization, H.E.B.; methodology, H.E.B.; writing-original draft preparation, H.E.B., C.S., and T.B.H.; writing-review and editing, H.E.B., C.S., and T.B.H. All authors have read and agreed to the published version of the manuscript.

Funding: This research received no external funding.

Institutional Review Board Statement: Not applicable.

Informed Consent Statement: Not applicable.

Data Availability Statement: Not applicable.

Conflicts of Interest: The authors declare no conflict of interest.

\section{Appendix A}

Table A1. List of the selected documents.

\section{Publication \\ Year}

\section{List of References}

Ajates [413]; Ajates [414]; Akinola et al. [415]; Al Sidawi et al. [416]; Alae-Carew et al. [417]; Albert et al. [418]; Al-Jawaldeh et al. [419]; Allaby et al. [388]; Amicarelli and Bux [420]; Amiri et al. [421]; Amiri et al. [422]; Andress et al. [423]; April-Lalonde et al. [424]; Aschemann-Witzel et al. [425]; Augstburger and Rist [426]; Augustin et al. [427]; Baiguzhinova et al. [428]; Bajželj et al. [429]; Baldos et al. [164];

Bartelmeß and Godemann [430]; Bas-Bellver et al. [431]; Basso and Antle [432]; Bazaluk et al. [433];

Becker et al. [132]; Beingessner and Fletcher [434]; Bellows [287]; Ben Hassen et al. [235]; Bencze et al. [435]; Béné et al. [386]; Béné et al. [436]; Benítez et al. [307]; Bentham et al. [437]; Berti [438]; Bisht et al. [198]; Bloom et al. [439]; Blumberg et al. [153]; Bocken et al. [440]; Borelli et al. [189]; Borsellino et al. [236]; Bounie et al. [220]; Boyer and Ramaswami [209]; Boylan et al. [441]; Brandão et al. [442]; Braun et al. [309]; Broekema et al. [313]; Bryceson and Ross [443]; Bumbac et al. [444]; Butler et al. [213]; Cadel et al. [445]; Cadillo-Benalcazar [365]; Campbell [175]; Carino et al. [446]; Carlsson et al. [447]; Cazcarro et al. [78]; Chable et al. [196]; Chapman and Perkins [448]; Chen et al. [76];

Chen et al. [75]; Clay et al. [449]; Coad and Pedley [450]; Colby [451]; Conner [452]; Covarrubias and Boas [106];

Cramer et al. [308]; Culliford and Bradbury [453]; Dai et al. [94]; Dalmoro et al. [454]; Davies et al. [455]; De

Bernardi et al. [411]; de Olde et al. [456]; de Sousa and Solberg [457]; Derunova et al. [458]; Derunova et al. [459];

Di Vaio et al. [460]; Diehl [214]; Dijkshoorn-Dekker et al. [461]; Dillon et al. [462]; Dorninger et al. [463];

Downs et al. [464]; Drewnowski et al. [253]; Duro et al. [119]; Duru and Le Bras [317]; Ebel [465];

Echeverría et al. [207]; El Bilali [43]; Eriksson et al. [466]; Esposito et al. [99]; Evans and Johnson [294]; Fardet and Rock [467]; Fardet and Rock [468]; Farmery et al. [469]; Feijoo and Moreira [470]; Fernandez-Mena et al. [230]; Fesenfeld et al. [471]; Fischer and Miglietta [472]; Fleischhacker et al. [320]; Fogarassy et al. [473];

Forber et al. [86]; Formoso et al. [474]; Fortes et al. [475]; Freed et al. [476]; Frison and Clément [477];

Gaitán-Cremaschi et al. [478]; Galli et al. [58]; García-Oliveira et al. [479]; Gausa et al. [480]; Gerritsen et al. [481]; Gerten et al. [61]; Gésan-Guiziou et al. [482]; Ginani et al. [483]; Girard [484]; Giudice et al. [98]; Granheim et al. [485]; Guareschi et al. [486]; Guarnaccia et al. [370]; Gugerell and Penker [487];

Guillaumie et al. [488]; Hanigan and Daley [489]; Hatanaka [490]; Haydon et al. [339]; Hedberg [88]; Hedberg and Zimmerer [247]; Helenius et al. [491]; Hendrickson et al. [492]; Hennchen and Pregernig [390]; Herrero et al. [493]; Heslin et al. [494]; Hilborn et al. [495]; Huang et al. [89]; Huan-Niemi et al. [496]; Jablonski et al. [357]; Jacob et al. [497]; Jacobi et al. [292]; Jehlička et al. [498]; Kahiluoto [389]; Kaufmann et al. [407]; Kemper and Ballantine [165]; Kim et al. [208]; King et al. [499]; Klerkx and Rose [500]; Kopainsky et al. [312]; Ku and Kan [501]; Kuo et al. [502]; Kusch-Brandt [503]; Lajoie-O'Malley et al. [504]; Le Noë et al. [59]; Leclère et al. [176]; Lee et al. [505]; Leite et al. [60]; Leone et al. [319]; Leroy et al. [66]; Lewis et al. [363]; Liang et al. [127]; Lonnie and Johnstone [314]; Lopez et al. [506]; Lourival and Rose [348]; Lowitt et al. [401]; Lu and Halog [231]; Mapiye et al. [507]; Mardones et al. [24]; Martindale et al. [508];

Martindale et al. [509]; Martinelli et al. [510]; Matacena and Corvo [511]; Maughan et al. [264]; Mayton et al. [512]; Mazzocchi and Marino [340]; Mazzocchi et al. [152]; McClements [513]; Mehta et al. [514]; Melesse et al. [371]; Metelerkamp et al. [193]; Meyer [515]; Michell et al. [516]; Millet et al. [517]; Moberg et al. [518]; Mora et al. [80]; Morel et al. [519]; Morris et al. [68]; Mulesa and Westengen [181]; Mullender et al. [520]; Muscio and Sisto [100]; Naja et al. [521]; Negra et al. [215]; Nicol and Taherzadeh [263]; Niederle and Schubert [522]; 
Table A1. Cont.

\begin{tabular}{ll}
$\begin{array}{c}\text { Publication } \\
\text { Year }\end{array} \quad$ List of References \\
\hline
\end{tabular}

Nosratabadi et al. [523]; Nowack and Hoffmann [524]; O'Kane and Pamphilon [525]; Omotayo [184]; Omotayo and Aremu [334]; Oo et al. [526]; Palmioli et al. [527]; Park et al. [528]; Pereira et al. [529]; Pham and Turner [322]; Pilipuk [530]; Przelomska et al. [531]; Queenan et al. [67]; Raheem [532]; Ray et al. [332]; Read et al. [101]; Reay et al. [533]; Reinhardt et al. [534]; Resnick [535]; Ricci and Banterle [163]; Ridoutt and Navarro Garcia [177]; Ringling and Marquart [203]; Rippin et al. [321]; Rockström et al. [34]; Rodak [301]; Roig Vila [536]; Rosol [537]; Rossi [538]; Sahal Alharbi et al. [539]; Sampedro et al. [540]; Savary et al. [20]; Schepelmann et al. [541]; Schiller et al. [542]; Schoof et al. [543]; Schramski et al. [95]; Seidel [544]; Sellberg et al. [545]; Sharma et al. [546]; Siegrist and Hartmann [547]; Sigurdsson et al. [548]; Sijtsema et al. [97]; Simón-Rojo et al. [549]; Smaal et al. [261]; 2020 Smetana et al. [550]; Soma et al. [551]; Sonnino and Coulson [552]; Stefanovic et al. [553]; Stentiford et al. [316]; Subedi et al. [115]; Sugimoto et al. [554]; Tapsoba et al. [555]; Tello et al. [81]; Temme et al. [375];

Thompson et al. [262]; Tittarelli [556]; Torres [557]; Tortorella et al. [162]; Tricarico et al. [558]; Triste et al. [559]; Ujuaje and Chang [560]; Unger [561]; Usubiaga-Liaño et al. [96]; Valley et al. [562];

van de Vlasakker and Veen [563]; van der Gaast et al. [564]; van Hulst et al. [195]; Vanham and Leip [77]; Vartanova [318]; Vermeulen et al. [372]; Villa et al. [565]; Warshawsky [566]; Weber et al. [567];

Weerasekara et al. [183]; Wegren and Trotsuk [161]; Weidner and Yang [568]; Weissman and Potteiger [377]; Wezel et al. [569]; Wigboldus et al. [570]; Withers et al. [85]; Wyngaarden et al. [71]; Wynne-Jones et al. [571]; Yang et al. [572]; Yang et al. [573]; Zafra-Aparici [574]; Zhang et al. [575]; Zhang et al. [576]

Abu Hatab et al. [577]; Ahmed et al. [354]; Aiking and de Boer [336]; Aleksandrowicz et al. [578]; Alexander et al. [83]; Allen et al. [579]; Álvarez Castaño et al. [580]; Anderson and Leach [581];

Anderson et al. [582]; Anderson et al. [583]; Anderson et al. [584]; Arfini et al. [585]; Arfini et al. [586]; Asano and Biermann [587]; Aschemann-Witzel et al. [588]; Athanatos and Mehrotra [589]; Baldy [343];

Baldy and Kruse [271]; Battersby and Watson [353]; Béné et al. [590]; Béné et al. [591]; Benton [592];

Bersamin et al. [593]; Blesh et al. [594]; Bogard et al. [595]; Bonanomi et al. [367]; Boogaard [596]; Bornemann and Weiland [274]; Bowles et al. [62]; Boyer et al. [143]; Boylan et al. [597]; Broad [598]; Bronson et al. [599];

Bruckner and Kowasch [600]; Bui et al. [297]; Bush et al. [601]; Cachelin et al. [266]; Canavan and Fawzi [602];

Capecchi et al. [603]; Carlsson et al. [604]; Chandrakumar et al. [605]; Chojnacki and Creamer [606]; Chopra [607];

Christman [608]; Cimini and Moresi [133]; Clapp [216]; Clark and Longo [129]; Colinas et al. [609];

Corallo et al. [610]; Corallo et al. [611]; Corke and Olewnik [612]; Corrado et al. [613]; Coteur et al. [614];

Cottrell et al. [615]; Cramer et al. [616]; Crenna et al. [178]; Dawson et al. [617]; De Bernardi et al. [155]; de Krom and Muilwijk [618]; de la Salle [619]; Derqui [620]; Derunova et al. [228]; Derunova et al. [621]; Ding et al. [324];

Doernberg et al. [341]; Dong et al. [391]; Drejerska et al. [622]; Dumont et al. [70]; Egolf et al. [623];

Eker et al. [624]; El Bilali [625]; El Bilali [626]; El Bilali [44]; Esculier et al. [627]; Fanzo and Davis [628]; Fassio

and Tecco [35]; Fernandez-Wulff [272]; Ferrari et al. [629]; Filippini et al. [342]; Finley and Fukagawa [630];

Flynn et al. [325]; Fridman and Kissinger [631]; Gaitan-Cremaschi et al. [632]; Garcia-Garcia et al. [633];

Garcia-Gonzalez and Eakin [634]; Garcia-Sempere et al. [635]; Ge et al. [636]; Gentry et al. [637]; Ghinea 2019 and Ghiuta [638]; Gillespie et al. [639]; Gliessman et al. [640]; Grant et al. [641]; Grubb and Vogl [398]; Guerrero Lara et al. [335]; Gumbert [273]; Gustafson et al. [642]; Gwin [643]; Halbe and Adamowski [644];

Haysom et al. [645]; Haythorn et al. [646]; Henchion et al. [647]; Horton et al. [104]; Huang et al. [648]; Huang et al. [90]; Hubeau et al. [649]; Jacobi et al. [403]; Jacobi et al. [650]; Janssens et al. [651]; Jeric and Soric [652]; Jin et al. [653]; Jones et al. [654]; Jongerden et al. [229]; Kissinger et al. [128];

Klerkx et al. [655]; Kok et al. [656]; Kos and Kloppenburg [412]; Kraus [221]; Kuokkanen et al. [657]; Lahatte et al. [658]; Lee et al. [659]; Li et al. [660]; Linder [661]; Liu et al. [323]; Lohest et al. [270];

Lombardi et al. [182]; Ma et al. [373]; Macdiarmid and Whybrow [166]; Machida and Yoshida [662]; Mangnus et al. [378]; Marsden et al. [663]; Martinelli and Cavalli [664]; Mastronardi et al. [154];

Mawois et al. [665]; Maye et al. [298]; McInnes [666]; Meier and Oehen [667]; Meneguzzo et al. [109]; Menozzi and Finardi [668]; Mohapatra et al. [669]; Moragues-Faus and Sonnino [344]; Munesue and Masui [102];

Muth et al. [103]; Nemes et al. [670]; Neves et al. [671]; Nikmaram and Rosentrater [672]; Noy et al. [673];

O'Brien and Nisbett [384]; Omotayo et al. [326]; Osman and Nelson [674]; Palumbo et al. [675]; Pan et al. [91]; Pihlajamäki et al. [676]; Prost [275]; Pulker et al. [677]; Quest et al. [385]; Raheem et al. [678];

Ramankutty et al. [679]; Recanati et al. [366]; Reuter [304]; Reynolds et al. [680]; Ridoutt et al. [681];

Rohmer et al. [682]; Rose and Lourival [683]; Rose et al. [684]; Rotz et al. [685]; Royo-Bordonada et al. [686]; Ruiz-Almeida and Rivera-Ferre [283]; Saint-Eve et al. [338]; Sambell et al. [687]; Santo and Moragues-Faus [383]; Schanes and Stagl [688]; Schier et al. [689]; Schreiber et al. [690]; Sharpe and Barling [299];

Shilomboleni et al. [691]; Si and Scott [692]; Silva and Sanjuán [693]; Sipple and Schanz [694]; Smetana et al. [695]; 
Table A1. Cont.

\begin{tabular}{cc}
$\begin{array}{c}\text { Publication } \\
\text { Year }\end{array}$ & List of References \\
\hline & Smetana et al. [696]; Smith [265]; Smith et al. [697]; Sodano [698]; Sokolow et al. [140]; Sonnino et al. [345]; \\
Sowerwine et al. [404]; Spring [174]; Stead [369]; Steiner et al. [19]; Subramaniam and Masron [699]; \\
Swagemakers et al. [700]; Takiya et al. [701]; Tisenkopfs et al. [300]; Tlusty et al. [702]; Vaccari et al. [87]; \\
Valencia et al. [703]; van Bers et al. [704]; van Hal et al. [73]; van Hal et al. [705]; van Oel et al. [79]; \\
Van Zanten et al. [72]; Veldhuis et al. [107]; Verneau et al. [706]; Vieira et al. [707]; Villoria [82]; \\
Virah-Sawmy et al. [708]; Visser et al. [709]; Vittersø et al. [150]; Voinea et al. [710]; Waage et al. [711]; \\
Warne et al. [712]; Warshawsky [713]; Warshawsky and Vos [714]; Weidner et al. [715]; Wetherill et al. [716]; \\
Yuan et al. [69]; Zhang et al. [108]
\end{tabular}

Ahmed et al. [717]; Ameso et al. [718]; Ball et al. [719]; Barnhill et al. [720]; Beacham [392]; Bertrand et al. [721];

Blay-Palmer et al. [376]; Blazquez et al. [722]; Brekken et al. [723]; Brinkley [724]; Bureau et al. [725]; Butrico and Kaplan [726]; Calancie et al. [379]; Campling and Havice [727]; Castrica et al. [728]; Cerrada-Serra et al. [729];

Chabin et al. [730]; Chaudhary et al. [374]; Chen et al. [731]; Chowdhury et al. [732]; Clapp [733]; Clapp and Isakson [734]; Coleman et al. [251]; Collier et al. [735]; Conijn et al. [64];

Conrad et al. [736]; Corrado and Sala [737]; Dame [738]; Dantas and Silva [739]; Davis et al. [740];

Delaney et al. [741]; Dermody et al. [742]; Derqui et al. [743]; Díaz and Reigada [744]; Donovan [399];

Drewnowski [745]; Drimie et al. [285]; Dumont et al. [746]; Eakin et al. [747]; Eckstein and Young [748];

El Bilali [749]; El Bilali et al. [123]; Elmes [240]; Fang et al. [750]; Figueroa-Helland et al. [751]; Fink et al. [752];

Finlayson [753]; Flores and Villalobos [754]; Forssell and Lankoski [755]; Freudenberg et al. [756]; Fridman and Kissinger [757]; Furman and Papavasiliou [758]; Gaddis and Coplen [259]; Gaechter and Porter [268];

Gallardo-López et al. [759]; Galli et al. [217]; Garcia-Sempere et al. [760]; Gilbert et al. [761]; Gisslevik et al. [762];

Glennie and Alkon [267]; Goggins [763]; Goralnik et al. [764]; Gragg et al. [110]; Grant et al. [765];

Grivins et al. [766]; Hanserud et al. [767]; Hashem et al. [768]; Haylock and Connelly [380]; Hebinck and Oostindie [769]; Hebinck et al. [219]; Hendry et al. [63]; Henriksson et al. [770]; Hernández et al. [771]; Heron et al. [772]; Herrera-Reyes et al. [773]; Heuschkel et al. [774]; Hoolohan et al. [775]; Huambachano [776]; Hubeau et al. [777]; Ilieva and Hernandez [778]; Infante-Amate et al. [779]; Ingenbleek and Zhao [780]; Jacobi and Llanque [284]; Jacobi et al. [781]; James et al. [782]; Jayashankar et al. [783]; Jedelhauser and Binder [784];

Jellil et al. [785]; Karlsson et al. [786]; Kennedy et al. [787]; Kumbamu [788]; Kuokkanen et al. [789];

Lamalice et al. [790]; Lang and Mason [355]; Larimore [791]; Laso et al. [114]; Laso et al. [792]; Lawlis et al. [793]; Le Noë et al. [794]; Levkoe et al. [795]; Liberatore et al. [796]; Limuwa et al. [797]; Lindgren et al. [798]; Lusk and McCluskey [337]; Mabhaudhi et al. [187]; Mantino and Forcina [799]; Maughan [800]; Mehr et al. [801]; Mesquita and Bursztym [170]; Mittal et al. [802]; Mohareb et al. [171]; Moragues-Faus and Marceau [803];

Morawicki and Gonzalez [804]; Moschitz [346]; Moschitzet al. [805]; Muchenje et al. [806]; Mulligan et al. [807];

Mylan [204]; Narayan and Jayakumar [808]; Nogeire-McRae et al. [809]; Olsson [810]; Osendarp et al. [811]; Paciarotti and Torregiani [812]; Peeters [315]; Pellegrini and Fernández [120]; Pereira et al. [813];

Pérez Neira et al. [134]; Pérez-Consuegra et al. [814]; Pitt et al. [815]; Plumecocq et al. [816]; Porter [269];

Pothukuchi [817]; Pothukuchi et al. [818]; Pulker et al. [819]; Rehkamp and Canning [210]; Ritchie et al. [820]; Ritchie et al. [167]; Ritchie et al. [168]; Ritchie et al. [821]; Rivera-Ferre [822]; Rizvi et al. [84]; Robinson [823];

Roblin et al. [350]; Rohmer et al. [824]; Röös et al. [194]; Ruben et al. [825]; Rut and Davies [826];

Rutten et al. [827]; Salavisa and de Fatima Ferreiro [828]; Sarkar et al. [234]; Schmidt and Matthies [829]; Schmutz et al. [151]; Scott [830]; Sebbane and Costa [831]; Seconda et al. [832];

Shepon et al. [833]; Slateret al. [834]; Solberg et al. [188]; Stein et al. [218]; Sušnik [835]; Taylor [836]; Teneva et al. [837]; Thompson [838]; Timpanaro et al. [149]; Torquebiau et al. [172]; Tribaldos et al. [839]; Turhan et al. [327]; Vaarst et al. [840]; Valley et al. [841]; van Dooren et al. [842]; van Kernebeek et al. [843]; Vandermeer et al. [844]; Vasa et al. [845]; Verger et al. [846]; Vroegindewey and Hodbod [847]; Wang et al. [111]; Waterlander et al. [848]; Wegeneret al. [849]; Withers et al. [850]; Yoon and Song [288]; Zheng et al. [851]; Zimmerman et al. [852]; Zurek et al. [250]; Zvaigzne et al. [853]

Adeyeye [854]; Agness et al. [359]; Ahmed et al. [855]; Alexander et al. [856]; Alexander et al. [857]; Alrøe et al. [858]; Arbit et al. [305]; Arcari [859]; Atkey et al. [360]; Audet et al. [237]; Barlett [860]; Bellamy and Ioris [861]; Bellante [862]; Benis and Ferrao [863]; Berardy and Chester [112]; Beretta et al. [105]; Berno [864];

Bogadottir and Olsen [865]; Boyer and Ramaswami [866]; Brimblecombe et al. [867]; Brzezina et al. [868]; Cardoso et al. [869]; Carlsson et al. [870]; Castellanos et al. [871]; Charles [872]; Clapp [873]; Conrad et al. [874];

Coppola and Ianuario [875]; De Marco et al. [381]; Deller et al. [876]; Derqui and Fernandez [877];

Downs et al. [349]; Dubbeling et al. [347]; Dudley et al. [179]; Eakin et al. [878]; Eakin et al. [879];

Ernsteins et al. [880]; Fagioli et al. [881]; Farmery et al. [882]; Fassio [883]; Fiisabiilillah and Maulana [884];

Finley et al. [885]; Forssell and Lankoski [886]; Francis et al. [887]; Galli et al. [888]; Gardner and Hauser [889];

Giuggioli et al. [890]; Gonzalez de Molina and Guzman [891]; Granvik et al. [892]; Hadjikakou [893];

Hallström et al. [894]; Hebinck and Page [409]; Heidelberger et al. [895]; Hessle et al. [896]; Horton et al. [897]; 
Table A1. Cont.

$\begin{gathered}\text { Publication } \\ \text { Year }\end{gathered}$
List of References
Hubeau et al. [898]; Islam [899]; Knickel et al. [900]; Koniordos et al. [901]; Kotir et al. [902]; Kuhmonen [903];
Kuokkanen et al. [65]; Laforge et al. [904]; Landert et al. [905]; Leventon and Laudan [906];
Ligrani and Niewolny [907]; Lozano-Cabedo and Gomez-Benito [908]; Lutz et al. [909]; McInnes et al. [910];
Messina et al. [911]; Meybeck and Gitz [912]; Meynard et al. [913]; Migliorini and Wezel [190]; Miles et al. [914];
Milestad et al. [915]; Moragues-Faus and Marsden [916]; Moragues-Faus et al. [917]; Murakami et al. [918];
Niewolny et al. [919]; Opitz et al. [920]; Palacios-Argueello et al. [921]; Paloviita [922]; Pensado-Leglise
and Smolski [923]; Peters et al. [924]; Polbitsyn [925]; Popkin [926]; Poulsen [927]; Reynolds [928]; Reynolds [929];
Ridoutt et al. [930]; Röös et al. [931]; Röös et al. [74]; Ryan-Fogarty et al. [932]; Sanye-Mengual et al. [933];
Seconda et al. [934]; Seekell et al. [935]; Shankar et al. [936]; Shilomboleni [937]; Simon et al. [402]; Singh-Peterson
and Lawrence [938]; Smith et al. [939]; Therond et al. [940]; Tlusty and Thorsen [941]; van Genuchten et al. [942];
van Vliet et al. [943]; VanWinkle [333]; Vastola et al. [199]; Vdovenko and Sokol [944]; Vinnari et al. [945];
Vivero-Pol [242]; Vivero-Pol [243]; von Oelreich and Milestad [946]; Voronin et al. [947]

Allen and Prosperi [948]; Alrøe and Noe [949]; Alrøe et al. [950]; Alsaffar [951]; Balázs et al. [393];

Baritaux et al. [952]; Batat et al. [953]; Bauermeister [954]; Bennetzen et al. [955]; Berti and Mulligan [956];

Bertmann and Yaroch [957]; Blay-Palmer et al. [958]; Brooks [959]; Brunori et al. [960]; Brzezina et al. [961];

Bui et al. [962]; Campbell [963]; Carlisle [964]; Castellanos et al. [965]; Chiffoleau et al. [276]; Cottee et al. [966];

Creech [967]; Crivits et al. [351]; Davies and Bowman [968]; Davis et al. [126]; DeHaan et al. [969];

DeLonge et al. [970]; Dixon and Richards [971]; Doernberg et al. [972]; Dou et al. [973]; Dyen and Sirieix [974];

Eades et al. [975]; Epting [976]; Fabinyi and Liu [977]; Fan and Brzeska [978]; Ferguson [979]; Fontoura et al. [980];

Friant [245]; Fry et al. [981]; Galli et al. [982]; Gasperi et al. [983]; Gillon [984]; Gjerris et al. [985];

Goggins and Rau [986]; Goldstein et al. [211]; Gonçalves et al. [987]; Grigsby and Hellwinckel [988];

Gustafson et al. [989]; Harris et al. [990]; Hatt et al. [991]; Heard and Miller [992]; Himanen et al. [993];

Hisschemoller [994]; Hobart [995]; Hoolohan et al. [996]; Horton et al. [997]; Hunter et al. [998]; Hvitsand [394];

James [999]; Jennings et al. [328]; Johnson et al. [1000]; Jurgilevich et al. [232]; Kline et al. [1001]; Konar et al. [141];

Kristensen et al. [222]; Kuokkanen et al. [1002]; Larsson et al. [1003]; Lassaletta et al. [92]; Li et al. [169]; Lo

and Delwiche [368]; Longo [1004]; Lopes [1005]; Lucifero [1006]; Lukito et al. [1007]; MacDonald et al. [124];

Manganiello [1008]; Martin et al. [1009]; McCarthy et al. [1010]; McClintock et al. [1011]; Meek and Tarlau [277];

Mench et al. [1012]; Metson et al. [160]; Meybeck and Gitz [1013]; Moledor et al. [1014]; Monasterolo et al. [1015];

Mourad [1016]; Mundler and Laughrea [223]; Napawan and Burke [1017]; Nau et al. [1018]; Neset et al. [1019];

Nhu et al. [1020]; O'Kane [1021]; O'Keefe et al. [1022]; Omoto and Scott [1023]; Opitz et al. [1024];

Paloviita et al. [1025]; Penvern et al. [1026]; Pérez Neira [256]; Pérez Neira et al. [144]; Peters et al. [1027]; Pitt and Jones [1028]; Ponisio and Ehrlich [1029]; Robinson et al. [145]; Rover et al. [408]; Rundgren [244]; Salgado-Sanchez and Castro-Ramirez [1030]; Sali et al. [1031]; Sjörs et al. [1032];

Smith et al. [1033]; Sonesson et al. [1034]; Sonnino [1035]; Sonnino et al. [1036]; Springmann et al. [1037];

Średnicka-Tober et al. [1038]; Stevens et al. [1039]; Svenfelt and Zapico [1040]; Thyberg and Tonjes [1041];

Uwizeye et al. [1042]; Valenzuela [1043]; Van den Broeck and Maertens [1044]; Vanham et al. [206]; Viola and Marinelli [1045]; Viola et al. [233]; Voinea et al. [1046]; Warshawsky [1047]; Weiler et al. [306];

Weiler et al. [290]; Wilson [1048]; Wright and Ostergard [118]; Wu et al. [1049]; Yamashita and Robinson [1050]; Zimdahl and Holtzer [1051]; Zirham and Palomba [1052]

Aguilar et al. [180]; Alajmi and Somerset [1053]; Allaert [224]; Allen [1054]; Allievi et al. [293];

Barbeau et al. [1055]; Belletti [1056]; Black et al. [1057]; Borska and Kadlecova [1058]; Brinsden and Lang [1059];

Burke and Spiller [1060]; Cadieux and Slocum [1061]; Carolan [1062]; Carroll and Fahy [1063]; Casolani [1064];

Chaudhury and Albinsson [1065]; Christensen and O'Sullivan [1066]; Cisneros-Saguilan et al. [1067]; Clapp [1068];

Clausen et al. [1069]; Cleveland et al. [146]; CoDyreet al. [1070];

Cohen and Ilieva [1071]; Cohen and Reynolds [1072]; Cook et al. [1073]; Cordell and White [1074]; Dentoni and Bitzer [1075]; Escajedo San-Epifanio [291]; Farber [1076]; Farmery et al. [135]; Forssell and Lankoski [1077];

2015 Frankova [1078]; Garnier et al. [158]; Göbel et al. [1079]; Godfray [121]; Godfray and Robinson [1080]; Grace [329];

Grivins and Tisenkopfs [1081]; Hallström et al. [1082]; Hawkes and Popkin [36]; Hayashi and Takemi [362];

Holben and Morrone [1083]; Horst and Gaolach [1084]; Hu et al. [1085]; Inman [225]; Jackson et al. [142]; James and Friel [1086]; Jenkins et al. [1087]; Johnson [1088]; Jones et al. [278]; Jonkman et al. [1089]; Kaput et al. [1090];

Kopainsky et al. [1091]; Krivasonoka and Silina [1092]; Krone [1093]; Kuhnlein [1094]; Langen et al. [1095];

Lawrence et al. [361]; Luckett et al. [186]; Marshall [1096]; Melece and Krievina [1097]; Metson and Bennett [1098];

Migliore et al. [1099]; Monroe et al. [1100]; Moragues-Faus and Morgan [1101]; Morgan [1102];

Motloch and Truex [1103]; Mukuve and Fenner [117]; Mukuve and Fenner [116]; Ng'endo et al. [185]; 
Table A1. Cont.

\begin{tabular}{|c|c|}
\hline $\begin{array}{c}\text { Publication } \\
\text { Year }\end{array}$ & List of References \\
\hline 2015 & $\begin{array}{l}\text { Nuutila [1104]; O'Kane and Wijaya [248]; Perryman and Schramski [130]; Pirog et al. [1105]; Pothukuchi } \\
\text { and Molnar [1106]; Rémésy et al. [1107]; Rudel et al. [125]; Saracin and Vasile [1108]; Schader et al. [1109]; } \\
\text { Shannon et al. [289]; Shimokawa [1110]; Springer et al. [1111]; Stanciu et al. [1112]; Straujuma [1113]; Sumner } \\
\text { and Wever [1114]; Tanaka et al. [1115]; Tendall et al. [1116]; Tieman and Hassan [1117]; } \\
\text { Tjärnemo and Södahl [1118]; Tsuchiya et al. [1119]; Vaarst et al. [1120]; van Grinsven et al. [260]; Vittersø } \\
\text { and Tangeland [1121]; Wilkinson [295]; Winters et al. [1122]; Xu et al. [136]; Zampi [1123]; Zhao et al. [1124] }\end{array}$ \\
\hline 2014 & $\begin{array}{l}\text { Ackerman et al. [1125]; Al-Ansari et al. [113]; Becker et al. [1126]; Bernstein [279]; Blecha and Leitner [1127]; } \\
\text { Caputo et al. [1128]; Challies et al. [1129]; Chico et al. [156]; Cleveland et al. [1130]; Climent-López et al. [1131]; } \\
\text { Cordell and Neset [1132]; Cordell and White [1133]; Davis et al. [1134]; Desmarais and Wittman [280]; Duram } \\
\text { and Mead [246]; Fanzo [1135]; Fielke and Bardsley [1136]; Francis et al. [1137]; Garnett [11]; Godfray [1138]; } \\
\text { Godfray and Garnett [55]; Goonan et al. [1139]; Halloran et al. [1140]; Hoekstra [1141]; Isakson [1142]; Johnston } \\
\text { et al. [1143]; Kjrgard et al. [1144]; Kuyper and Struik [122]; Lamppa et al. [1145]; Li et al. [406]; Marschke } \\
\text { and Wilkings [1146]; Mintz and McManus [400]; Monardo and Palazzo [1147]; Moresi [1148]; Odegard and van } \\
\text { der Voet [1149]; Olson et al. [1150]; Otiman et al. [352]; Peano et al. [1151]; Pearson et al. [1152]; } \\
\text { Pereira et al. [1153]; Pinstrup-Andersen [252]; Ridoutt et al. [1154]; Sabaté and Soret [205]; Senanayake } \\
\text { and Mukherji [1155]; Sneyd [1156]; Sonnino et al. [358]; Specht et al. [1157]; Thorsøe et al. [1158]; } \\
\text { van Mil et al. [1159]; Voisin et al. [1160]; Walter et al. [1161]; Wegerif [1162]; Werkheiser and Noll [1163]; } \\
\text { Werner et al. [137]; West et al. [1164]; Westhoek et al. [159]; Yach [1165]; Zanecchia [1166] }\end{array}$ \\
\hline 2013 & $\begin{array}{l}\text { Aoki and Akai [138]; Balazs [395]; Cassidy et al. [1167]; Cembalo et al. [1168]; Cordell et al. [1169]; Crivits } \\
\text { and Paredis [1170]; Dicks et al. [1171]; Fernandez et al. [1172]; Fraser [1173]; Galt et al. [1174]; Garnett [1175]; } \\
\text { Gerlach and Loring [1176]; Gliessman [202]; Glowacki-Dudka et al. [1177]; Gonzalez de Molina [1178]; } \\
\text { Hamilton [1179]; Herrero et al. [54]; Hinrichs [1180]; Infante Amate and Gonzalez de Molina [257]; } \\
\text { Ingram et al. [1181]; Johns et al. [1182]; Kissinger [131]; Kneafsey et al. [1183]; Lutz and Schachinger [281]; } \\
\text { MacRae et al. [1184]; McLachlan and Landman [1185]; Miewald et al. [330]; Pereira [1186]; Rosin [1187]; Shey } \\
\text { and Belis [1188]; Sodano and Hingley [1189]; Sonnino [1190]; Spiegelaar and Tsuji [1191]; Spiegelaar et al. [1192]; } \\
\text { Vinceti et al. [1193]; White and Stirling [1194] }\end{array}$ \\
\hline
\end{tabular}

Anthony [1195]; Blanc and Kledal [1196]; Brunori et al. [1197]; Elser [1198]; Erb et al. [1199]; Gliessman [201];

Guzmán et al. [405]; Kimmons et al. [356]; Kissinger [147]; Kremen et al. [1200]; Lang and Barling [1201]; Longo

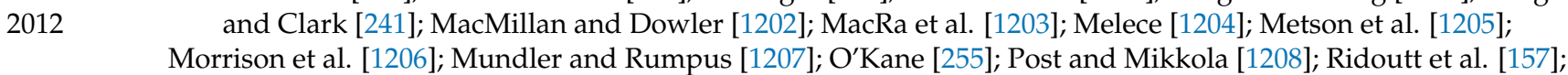
Seufert et al. [49]; Tai [1209]; Warbach et al. [1210]; Yu et al. [173]; Zhou et al. [1211]; Zhou et al. [1212]

Aiking [1213]; Barlett [1214]; Bean and Sharp [1215]; Bloom and Hinrichs [1216]; Bush and Duijf [1217]; Challies and Murray [212]; DeLind [1218]; Dunne et al. [1219]; Ervin et al. [1220]; Garnett [53];

2011 Kelly and Schulschenk [226]; Kniuksta and Caplikas [227]; Kremer [1221]; McCune et al. [1222]; McMichael [1223];

Medina [1224]; Melece [1225]; Metcalf and Widener [1226]; Phalan et al. [1227]; Reeve et al. [197]; Rojas [1228];

Sonnino and McWilliam [1229]; Tansey [1230]; Thibert and Badami [1231]; Virtanen et al. [139]; White et al. [1232]

Adams and Salois [1233]; Allen [1234]; Boyer [282]; Click and Ridberg [1235]; Condon et al. [1236]; Cuellar 2010 and Webber [1237]; Gillespie [1238]; Godfray et al. [48]; Godfray et al. [1239]; Howard and Allen [1240];

Kirschenmann [1241]; Mikkola et al. [1242]; Milestad et al. [1243]; Milestad et al. [249]; Moore [1244]; Morgan [1245]; Morgan and Sonnino [1246]; Reilly and Willenbockel [1247]; Woeste et al. [1248]; Young [1249]

Alkon and Norgaard [1250]; Alpas and Kiymaz [1251]; Chiu and Lin [296]; Coley et al. [148]; Ferreira et al. [1252]; Fiscus [1253]; Fresco [1254]; Huang et al. [1255]; Komisar et al. [1256]; Kurita et al. [1257]; Li and Hu [1258]; 2009 Loring and Gerlach [1259]; Mikkola [1260]; Peters et al. [1261]; Porcher [396]; Schönhart et al. [1262]; Stroink and Nelson [1263]; Thompson and Scoones [1264]; Trauger [1265]; Wallgren and Hojer [1266]; Wezel and Soldat [1267]; Wezel et al. [57]; Yang and Hanson [1268] and Schiefer [1272]; Getz et al. [192]; Guthman [1273]; Islam [1274]; Lowe et al. [1275]; Mariola [1276]; Wahlqvist [1277]; Yach [238] Parr et al. [1283]; Rojas et al. [1284]; Schmid et al. [1285]; Wahlqvist and Lee [331] 
Table A1. Cont.

\begin{tabular}{cc}
$\begin{array}{c}\text { Publication } \\
\text { Year }\end{array}$ & List of References \\
\hline 2005 & $\begin{array}{c}\text { Barton et al. [1292]; Buttel [1293]; DuPuis and Goodman [51]; Johnston and Baker [1294]; } \\
\text { Kriflik and Yeatman [1295]; Lozier et al. [1296]; Natarajan et al. [1297]; Ostrom and Jackson [1298]; } \\
\text { Pingali et al. [1299]; Pretty et al. [254]; Sundkvist et al. [1300]; Wilkins [387]; Winne [1301]; Wivstad et al. [93] }\end{array}$ \\
\hline 2004 & Caraher and Coveney [239]; Clancy [1302]; Kratochvil et al. [1303]; Pothukuchi [1304]; Stonehouse [1305]; \\
Vallianatos et al. [1306]
\end{tabular}

\section{References}

1. United Nations. Food Systems Summit 2021-About the Summit. Available online: https://www.un.org/en/food-systemssummit/about (accessed on 18 February 2021).

2. United Nations. Food Systems Summit 2021-Action Tracks. Available online: https://www.un.org/en/food-systems-summit/ action-tracks (accessed on 18 February 2021).

3. European Commission. What is the European Green Deal? Available online: https:/ / ec.europa.eu/commission/presscorner/ api/files/attachment/859152/What_is_the_European_Green_Deal_en.pdf.pdf (accessed on 10 February 2021).

4. European Commission. A European Green Deal—Striving to be the First Climate-Neutral Continent. Available online: https:/ / ec.europa.eu/info/strategy/priorities-2019-2024/european-green-deal_en (accessed on 18 February 2021).

5. European Commission. Europe's Moment: Repair and Prepare for the Next Generation. Available online: https:/ / ec.europa.eu/ commission/presscorner/api/files/document/print/en/ip_20_940/IP_20_940_EN.pdf (accessed on 18 February 2021).

6. European Commission. A Farm to Fork Strategy for a Fair, Healthy and Environmentally-Friendly Food System. Available online: https:/ / ec.europa.eu/food/farm2fork_en (accessed on 18 February 2021).

7. European Commission. From Farm to Fork-Our food, our Health, Our Planet, Our Future. Available online: https:/ / ec.europa.eu/ info/strategy/priorities-2019-2024/european-green-deal/actions-being-taken-eu/farm-fork_en (accessed on 18 February 2021).

8. HLPE. Food Losses and Waste in the Context of Sustainable Food Systems; HLPE: Rome, Italy, 2014.

9. GAIN. Johns Hopkins University About Food Systems. Available online: https://foodsystemsdashboard.org/about-foodsystem (accessed on 11 November 2020).

10. Ericksen, P.J. Conceptualizing food systems for global environmental change research. Glob. Environ. Chang. 2008, 18, 234-245. [CrossRef]

11. Garnett, T. Three perspectives on sustainable food security: Efficiency, demand restraint, food system transformation. What role for life cycle assessment? J. Clean. Prod. 2014, 73, 10-18. [CrossRef]

12. Gladek, E.; Fraser, M.; Roemers, G.; Sabag Munoz, O.; Hirsch, P.; Kennedy, E. The Global Food System: An Analysis; Metabolic: Amsterdam, The Netherlands, 2016.

13. IPES-Food The New Science of Sustainable Food Systems: Overcoming Barriers to Food Systems Reform. Available online: http:/ / www.ipes-food.org/images/Reports /IPES_report01_1505_web_br_pages.pdf (accessed on 10 October 2017).

14. Lang, T. Food Security and Sustainability: The Perfect Fit; Sustainable Development Commission (SDC): London, UK, 2009.

15. FAO. Building a Common Vision for Sustainable Food and Agriculture_Principles and Approaches; FAO: Rome, Italy, 2014.

16. Foresight. The Future of Food and Farming. Final Project Report; Foresight: London, UK, 2011.

17. WWW-UK. A 2020 vision for the Global Food System. Report Summary. Available online: http:/ / assets.wwf.org.uk/downloads / 2020vision_food_report_summary_feb2013.pdf (accessed on 15 April 2018).

18. FAO; IFAD; UNICEF; WFP; WHO. The State of Food Security and Nutrition in the World 2020; FAO: Rome, Italy, 2020.

19. Steiner, G.; Geissler, B.; Schernhammer, E. Hunger and Obesity as Symptoms of Non-Sustainable Food Systems and Malnutrition. Appl. Sci. 2019, 9, 1062. [CrossRef] 
20. Savary, S.; Akter, S.; Almekinders, C.; Harris, J.; Korsten, L.; Rötter, R.; Waddington, S.; Watson, D. Mapping disruption and resilience mechanisms in food systems. Food Secur. 2020, 12, 695-717. [CrossRef] [PubMed]

21. Rivera-Ferre, M.G.; López-i-Gelats, F.; Ravera, F.; Oteros-Rozas, E.; di Masso, M.; Binimelis, R.; El Bilali, H. The two-way relationship between food systems and the COVID19 pandemic: Causes and consequences. Agric. Syst. 2021, 191, 103134. [CrossRef]

22. Ben Hassen, T.; El Bilali, H.; Allahyari, M.S.; Berjan, S.; Fotina, O. Food purchase and eating behavior during the COVID-19 pandemic: A cross-sectional survey of Russian Adults. Appetite 2021, 105309. [CrossRef] [PubMed]

23. Rodríguez-Pérez, C.; Molina-Montes, E.; Verardo, V.; Artacho, R.; García-Villanova, B.; Guerra-Hernández, E.J.; Ruíz-López, M.D. Changes in Dietary Behaviours during the COVID-19 Outbreak Confinement in the Spanish COVIDiet Study. Nutrients 2020, 12, 1730. [CrossRef] [PubMed]

24. Mardones, F.O.; Rich, K.M.; Boden, L.A.; Moreno-Switt, A.I.; Caipo, M.L.; Zimin-Veselkoff, N.; Alateeqi, A.M.; Baltenweck, I. The COVID-19 Pandemic and Global Food Security. Front. Vet. Sci. 2020, 7, 928. [CrossRef]

25. Stephens, E.C.; Martin, G.; van Wijk, M.; Timsina, J.; Snow, V. Editorial: Impacts of COVID-19 on agricultural and food systems worldwide and on progress to the sustainable development goals. Agric. Syst. 2020, 183, 102873. [CrossRef]

26. Dyson, T. Population and Food; Routledge: London, UK, 1996.

27. FAO. World Agriculture: Towards 2015/2030; FAO: Rome, Italy, 2002.

28. FAO; IFAD; WFP. The State of Food Insecurity in the World 2015. Meeting the 2015 International Hunger Targets: Taking Stock of Uneven Progress; FAO; IFAD; WFP: Rome, Italy, 2015.

29. El Bilali, H.; Callenius, C.; Strassner, C.; Probst, L. Food and nutrition security and sustainability transitions in food systems. Food Energy Secur. 2019, 8, e00154. [CrossRef]

30. American Dietetic Association. Healthy Land, Healthy People. Building a Better Understanding of Sustainable Food Systems for Food and Nutrition Professionals. A Primer on Sustainable Food Systems and Emerging Roles for Food and Nutrition Professionals; American Dietetic Association: Chicago, IL, USA, 2007.

31. American Public Health Association. Toward a Healthy Sustainable Food System. Available online: https://www.apha.org/ policies-and-advocacy/public-health-policy-statements/policy-database/2014/07/29/12/34/toward-a-healthy-sustainablefood-system (accessed on 10 February 2017).

32. CRCResearch. Definition of a Sustainable Food System. Available online: https://www.crcresearch.org/sites/default/files/u6 41/definition_of_a_sustainable_food_system.pdf (accessed on 10 February 2017).

33. United Nations General Assembly. Transforming Our World: The 2030 Agenda for Sustainable Development; United Nations General Assembly: New York, NY, USA, 2015.

34. Rockström, J.; Edenhofer, O.; Gaertner, J.; DeClerck, F. Planet-proofing the global food system. Nat. Food 2020, 1, 3-5. [CrossRef]

35. Fassio, F.; Tecco, N. Circular Economy for Food: A Systemic Interpretation of 40 Case Histories in the Food System in Their Relationships with SDGs. Systems 2019, 7, 43. [CrossRef]

36. Hawkes, C.; Popkin, B.M. Can the sustainable development goals reduce the burden of nutrition-related non-communicable diseases without truly addressing major food system reforms? BMC Med. 2015, 13, 143. [CrossRef]

37. Rockström, J.; Sukhdev, P. How food connects all the SDGs. Available online: https:/ /www.stockholmresilience.org/research/ research-news/2016-06-14-how-food-connects-all-the-sdgs.html (accessed on 5 February 2017).

38. HLPE. 2nd Note on Critical and Emerging Issues for Food Security and Nutrition. A Note by the High Level Panel of Experts on Food Security and Nutrition (HLPE) of the Committee on World Food Security; HLPE: Rome, Italy, 2017.

39. United Nations Conference on Trade and Development. The Role of Science, Technology and Innovation in Ensuring Food Security by 2030; United Nations Conference on Trade and Development: New York, NY, USA; Geneva, Switzerland, 2017.

40. Nilsson, M.; Griggs, D.; Visbeck, M.; Ringler, C. A Draft Framework for Understanding SDG Interactions. Available online: https:/ / council.science/publications/working-paper-a-draft-framework-for-understanding-sdg-interactions-2016 (accessed on 5 February 2017).

41. Scholes, M.; Ringler, C.; von Braun, J. Goal 2-End hunger, achieve food security and improved nutrition, and promote sustainable agriculture. In Review of the Sustainable Development Goals: The Science Perspective; International Council for Science (ICSU), ISSC, Eds.; International Council for Science (ICSU): Paris, France, 2015; pp. 19-22.

42. Moher, D.; Liberati, A.; Tetzlaff, J.; Altman, D.G. Preferred Reporting Items for Systematic Reviews and Meta-Analyses: The PRISMA Statement. PLoS Med. 2009, 6, e1000097. [CrossRef]

43. El Bilali, H. Transition heuristic frameworks in research on agro-food sustainability transitions. Environ. Dev. Sustain. 2020, 22, 1693-1728. [CrossRef]

44. El Bilali, H. Research on agro-food sustainability transitions: Where are food security and nutrition? Food Secur. 2019, 11, 559-577. [CrossRef]

45. FAO. SAFA Sustainability Assessment of Food and Agriculture Systems_Guidelines Version 3.0; FAO: Rome, Italy, 2014.

46. FAO. Sustainability Assessment of Food and Agricultural System: Indicators; FAO: Rome, Italy, 2013.

47. Dahlberg, K.A. A transition from agriculture to regenerative food systems. Futures 1994, 26, 170-179. [CrossRef]

48. Godfray, H.C.J.; Beddington, J.R.; Crute, I.R.; Haddad, L.; Lawrence, D.; Muir, J.F.; Pretty, J.; Robinson, S.; Thomas, S.M.; Toulmin, C. Food Security: The Challenge of Feeding 9 Billion People. Science 2010, 327, 812-818. [CrossRef]

49. Seufert, V.; Ramankutty, N.; Foley, J.A. Comparing the yields of organic and conventional agriculture. Nature 2012, 485, $229-232$. [CrossRef] 
50. Hinrichs, C.C. Embeddedness and local food systems: Notes on two types of direct agricultural market. J. Rural Stud. 2000, 16, 295-303. [CrossRef]

51. DuPuis, E.M.; Goodman, D. Should we go "home" to eat?: Toward a reflexive politics of localism. J. Rural Stud. 2005, 21, 359-371. [CrossRef]

52. Pimentel, D.; Pimentel, M. Sustainability of meat-based and plant-based diets and the environment. Am. J. Clin. Nutr. 2003, 78, 660S-663S. [CrossRef]

53. Garnett, T. Where are the best opportunities for reducing greenhouse gas emissions in the food system (including the food chain)? Food Policy 2011, 36, S23-S32. [CrossRef]

54. Herrero, M.; Havlik, P.; Valin, H.; Notenbaert, A.; Rufino, M.C.; Thornton, P.K.; Blummel, M.; Weiss, F.; Grace, D.; Obersteiner, M. Biomass use, production, feed efficiencies, and greenhouse gas emissions from global livestock systems. Proc. Natl. Acad. Sci. USA 2013, 110, 20888-20893. [CrossRef]

55. Godfray, H.C.J.; Garnett, T. Food security and sustainable intensification. Philos. Trans. R. Soc. B Biol. Sci. 2014, $369,20120273$. [CrossRef]

56. Allen, P.; FitzSimmons, M.; Goodman, M.; Warner, K. Shifting plates in the agrifood landscape: The tectonics of alternative agrifood initiatives in California. J. Rural Stud. 2003, 19, 61-75. [CrossRef]

57. Wezel, A.; Bellon, S.; Doré, T.; Francis, C.; Vallod, D.; David, C. Agroecology as a science, a movement and a practice. A review. Agron. Sustain. Dev. 2009, 29, 503-515. [CrossRef]

58. Galli, A.; Moreno Pires, S.; Iha, K.; Alves, A.A.; Lin, D.; Mancini, M.S.; Teles, F. Sustainable food transition in Portugal: Assessing the Footprint of dietary choices and gaps in national and local food policies. Sci. Total Environ. 2020, 749, 141307. [CrossRef]

59. Le Noë, J.; Roux, N.; Billen, G.; Gingrich, S.; Erb, K.-H.; Krausmann, F.; Thieu, V.; Silvestre, M.; Garnier, J. The phosphorus legacy offers opportunities for agro-ecological transition (France 1850-2075). Environ. Res. Lett. 2020, 15, 064022. [CrossRef]

60. Costa Leite, J.; Caldeira, S.; Watzl, B.; Wollgast, J. Healthy low nitrogen footprint diets. Glob. Food Sec. 2020, 24, 100342. [CrossRef]

61. Gerten, D.; Heck, V.; Jägermeyr, J.; Bodirsky, B.L.; Fetzer, I.; Jalava, M.; Kummu, M.; Lucht, W.; Rockström, J.; Schaphoff, S.; et al. Feeding ten billion people is possible within four terrestrial planetary boundaries. Nat. Sustain. 2020, 3, 200-208. [CrossRef]

62. Bowles, N.; Alexander, S.; Hadjikakou, M. The livestock sector and planetary boundaries: A 'limits to growth' perspective with dietary implications. Ecol. Econ. 2019, 160, 128-136. [CrossRef]

63. Henry, R.C.; Engström, K.; Olin, S.; Alexander, P.; Arneth, A.; Rounsevell, M.D.A. Food supply and bioenergy production within the global cropland planetary boundary. PLOS ONE 2018, 13, e0194695. [CrossRef]

64. Conijn, J.G.; Bindraban, P.S.; Schröder, J.J.; Jongschaap, R.E.E. Can our global food system meet food demand within planetary boundaries? Agric. Ecosyst. Environ. 2018, 251, 244-256. [CrossRef]

65. Kuokkanen, A.; Mikkilä, M.; Kuisma, M.; Kahiluoto, H.; Linnanen, L. The need for policy to address the food system lock-in: A case study of the Finnish context. J. Clean. Prod. 2017, 140, 933-944. [CrossRef]

66. Leroy, F.; Hite, A.H.; Gregorini, P. Livestock in Evolving Foodscapes and Thoughtscapes. Front. Sustain. Food Syst. $2020,4,105$. [CrossRef]

67. Queenan, K.; Sobratee, N.; Davids, R.; Mabhaudhi, T.; Chimonyo, M.; Slotow, R.; Shankar, B.; Häsler, B. A Systems Analysis and Conceptual System Dynamics Model of the Livestock-derived Food System in South Africa: A Tool for Policy Guidance. J. Agric. Food Syst. Community Dev. 2020, 9, 021. [CrossRef]

68. Morris, J.; Ensor, J.E.; Pfeifer, C.; Marchant, R.; Mulatu, D.W.; Soka, G.; Ouédraogo-Koné, S.; Wakeyo, M.B.; Topi, C. Games as boundary objects: Charting trade-offs in sustainable livestock transformation. Int. J. Agric. Sustain. 2020, 18, 1-24. [CrossRef]

69. Yuan, Z.; Ji, J.; Sheng, H.; Jiang, S.; Chen, T.; Liu, X.; Liu, X.; Zhuang, Y.; Zhang, L. Animal based diets and environment: Perspective from phosphorus flow quantifications of livestock and poultry raising in China. J. Environ. Manag. 2019, 244, 199-207. [CrossRef]

70. Dumont, B.; Ryschawy, J.; Duru, M.; Benoit, M.; Chatellier, V.; Delaby, L.; Donnars, C.; Dupraz, P.; Lemauviel-Lavenant, S.; Méda, B.; et al. Review: Associations among goods, impacts and ecosystem services provided by livestock farming. Animal 2019, 13, 1773-1784. [CrossRef]

71. Wyngaarden, S.L.; Lightburn, K.K.; Martin, R.C. Optimizing livestock feed provision to improve the efficiency of the agri-food system. Agroecol. Sustain. Food Syst. 2020, 44, 188-214. [CrossRef]

72. Van Zanten, H.H.E.; Van Ittersum, M.K.; De Boer, I.J.M. The role of farm animals in a circular food system. Glob. Food Sec. 2019, 21, 18-22. [CrossRef]

73. Van Hal, O.; de Boer, I.J.M.; Muller, A.; de Vries, S.; Erb, K.-H.; Schader, C.; Gerrits, W.J.J.; van Zanten, H.H.E. Upcycling food leftovers and grass resources through livestock: Impact of livestock system and productivity. J. Clean. Prod. 2019, 219, 485-496. [CrossRef]

74. Röös, E.; Bajželj, B.; Smith, P.; Patel, M.; Little, D.; Garnett, T. Greedy or needy? Land use and climate impacts of food in 2050 under different livestock futures. Glob. Environ. Chang. 2017, 47, 1-12. [CrossRef]

75. Chen, J.; Zhou, Z.; Chen, L.; Ding, T. Optimization of Regional Water-Energy-Food Systems Based on Interval Number Multi-Objective Programming: A Case Study of Ordos, China. Int. J. Environ. Res. Public Health 2020, 17, 7508. [CrossRef]

76. Chen, J.; Ding, T.; Li, M.; Wang, H. Multi-Objective Optimization of a Regional Water-Energy-Food System Considering Environmental Constraints: A Case Study of Inner Mongolia, China. Int. J. Environ. Res. Public Health 2020, 17, 6834. [CrossRef] 
77. Vanham, D.; Leip, A. Sustainable food system policies need to address environmental pressures and impacts: The example of water use and water stress. Sci. Total Environ. 2020, 730, 139151. [CrossRef]

78. Cazcarro, I.; Duarte, R.; Sánchez Chóliz, J.; Sarasa, C. Water and production reallocation in the Spanish agri-food system. Econ. Syst. Res. 2020, 32, 278-299. [CrossRef]

79. Van Oel, P.; Chukalla, A.; Vos, J.; Hellegers, P. Using indicators to inform the sustainable governance of water-for-food systems. Curr. Opin. Environ. Sustain. 2019, 40, 55-62. [CrossRef]

80. Mora, O.; Le Mouël, C.; de Lattre-Gasquet, M.; Donnars, C.; Dumas, P.; Réchauchère, O.; Brunelle, T.; Manceron, S.; Marajo-Petitzon, E.; Moreau, C.; et al. Exploring the future of land use and food security: A new set of global scenarios. PLoS ONE 2020, 15, e0235597. [CrossRef]

81. Tello, J.; Garcillán, P.P.; Ezcurra, E. How dietary transition changed land use in Mexico. AMBIO 2020, 49, 1676-1684. [CrossRef]

82. Villoria, N. Consequences of agricultural total factor productivity growth for the sustainability of global farming: Accounting for direct and indirect land use effects. Environ. Res. Lett. 2019, 14, 125002. [CrossRef]

83. Alexander, P.; Reddy, A.; Brown, C.; Henry, R.C.; Rounsevell, M.D.A. Transforming agricultural land use through marginal gains in the food system. Glob. Environ. Chang. 2019, 57, 101932. [CrossRef]

84. Rizvi, S.; Pagnutti, C.; Fraser, E.; Bauch, C.T.; Anand, M. Global land use implications of dietary trends. PLoS ONE 2018, 13, e0200781. [CrossRef]

85. Withers, P.J.A.; Forber, K.G.; Lyon, C.; Rothwell, S.; Doody, D.G.; Jarvie, H.P.; Martin-Ortega, J.; Jacobs, B.; Cordell, D.; Patton, M.; et al. Towards resolving the phosphorus chaos created by food systems. AMBIO 2020, 49, 1076-1089. [CrossRef]

86. Forber, K.J.; Rothwell, S.A.; Metson, G.S.; Jarvie, H.P.; Withers, P.J.A. Plant-based diets add to the wastewater phosphorus burden. Environ. Res. Lett. 2020, 15, 094018. [CrossRef]

87. Vaccari, D.A.; Powers, S.M.; Liu, X. Demand-Driven Model for Global Phosphate Rock Suggests Paths for Phosphorus Sustainability. Environ. Sci. Technol. 2019, 53, 10417-10425. [CrossRef]

88. Hedberg, R.C. Coming Out of the Foodshed: Phosphorus Cycles and the Many Scales of Local Food. Ann. Am. Assoc. Geogr. 2020, 110, 684-704. [CrossRef]

89. Huang, W.; Gao, B.; Lin, J.; Cui, S.; Zhong, Q.; Huang, C. Driving forces of nitrogen input into city-level food systems: Comparing a food-source with a food-sink prefecture-level city in China. Resour. Conserv. Recycl. 2020, 160, 104850. [CrossRef]

90. Huang, W.; Gao, B.; Huang, Y.; Zhang, Z.; Xu, S.; Xu, L.; Cui, S. Transforming nitrogen management of the urban food system in a food-sink city. J. Environ. Manag. 2019, 249, 109180. [CrossRef] [PubMed]

91. Pan, J.; Ding, N.; Yang, J. Changes of urban nitrogen metabolism in the Beijing megacity of China, 2000-2016. Sci. Total Environ. 2019, 666, 1048-1057. [CrossRef] [PubMed]

92. Lassaletta, L.; Billen, G.; Garnier, J.; Bouwman, L.; Velazquez, E.; Mueller, N.D.; Gerber, J.S. Nitrogen use in the global food system: Past trends and future trajectories of agronomic performance, pollution, trade, and dietary demand. Environ. Res. Lett. 2016, 11, 095007. [CrossRef]

93. Wivstad, M.; Dahlin, A.S.; Grant, C. Perspectives on nutrient management in arable farming systems. Soil Use Manag. 2005, 21, 113-121. [CrossRef]

94. Dai, T.; Yang, Y.; Wemhoff, A.P. The On-Site Energy Demand of Meats Consumed in Restaurants. Resour. Conserv. Recycl. 2020, 160, 104845. [CrossRef]

95. Schramski, J.R.; Woodson, C.B.; Brown, J.H. Energy use and the sustainability of intensifying food production. Nat. Sustain. 2020, 3, 257-259. [CrossRef]

96. Usubiaga-Liaño, A.; Behrens, P.; Daioglou, V. Energy use in the global food system. J. Ind. Ecol. 2020, 24, 830-840. [CrossRef]

97. Sijtsema, S.J.; Fogliano, V.; Hageman, M. Tool to Support Citizen Participation and Multidisciplinarity in Food Innovation: Circular Food Design. Front. Sustain. Food Syst. 2020, 4, 1-12. [CrossRef]

98. Giudice, F.; Caferra, R.; Morone, P. COVID-19, the food system and the circular economy: Challenges and opportunities. Sustainability 2020, 12, 7939. [CrossRef]

99. Esposito, B.; Sessa, M.R.; Sica, D.; Malandrino, O. Towards circular economy in the agri-food sector. a systematic literature review. Sustainability 2020, 12, 7401. [CrossRef]

100. Muscio, A.; Sisto, R. Are Agri-Food Systems Really Switching to a Circular Economy Model? Implications for European Research and Innovation Policy. Sustainability 2020, 12, 5554. [CrossRef]

101. Read, Q.D.; Brown, S.; Cuéllar, A.D.; Finn, S.M.; Gephart, J.A.; Marston, L.T.; Meyer, E.; Weitz, K.A.; Muth, M.K. Assessing the environmental impacts of halving food loss and waste along the food supply chain. Sci. Total Environ. 2020, 712, 136255. [CrossRef]

102. Munesue, Y.; Masui, T. The impacts of Japanese food losses and food waste on global natural resources and greenhouse gas emissions. J. Ind. Ecol. 2019, 23, 1196-1210. [CrossRef]

103. Muth, M.K.; Birney, C.; Cuéllar, A.; Finn, S.M.; Freeman, M.; Galloway, J.N.; Gee, I.; Gephart, J.; Jones, K.; Low, L.; et al. A systems approach to assessing environmental and economic effects of food loss and waste interventions in the United States. Sci. Total Environ. 2019, 685, 1240-1254. [CrossRef]

104. Horton, P.; Bruce, R.; Reynolds, C.; Milligan, G. Food Chain Inefficiency (FCI): Accounting Conversion Efficiencies Across Entire Food Supply Chains to Re-define Food Loss and Waste. Front. Sustain. Food Syst. 2019, 3, 79. [CrossRef] 
105. Beretta, C.; Stucki, M.; Hellweg, S. Environmental Impacts and Hotspots of Food Losses: Value Chain Analysis of Swiss Food Consumption. Environ. Sci. Technol. 2017, 51, 11165-11173. [CrossRef]

106. Covarrubias, M.; Boas, I. The making of a sustainable food city in Barcelona: Insights from the water, energy, and food urban nexus. J. Integr. Environ. Sci. 2020, 17, 1-19. [CrossRef]

107. Veldhuis, A.J.; Glover, J.; Bradley, D.; Behzadian, K.; López-Avilés, A.; Cottee, J.; Downing, C.; Ingram, J.; Leach, M.; Farmani, R.; et al. Re-distributed manufacturing and the food-water-energy nexus: Opportunities and challenges. Prod. Plan. Control 2019, 30, 593-609. [CrossRef]

108. Zhang, P.; Xu, Z.; Fan, W.; Ren, J.; Liu, R.; Dong, X. Structure Dynamics and Risk Assessment of Water-Energy-Food Nexus: A Water Footprint Approach. Sustainability 2019, 11, 1187. [CrossRef]

109. Meneguzzo, F.; Zabini, F.; Albanese, L.; Crisci, A. Novel Affordable, Reliable and Efficient Technologies to Help Addressing the Water-Energy-Food Nexus. Eur. J. Sustain. Dev. 2019, 8, 1-17. [CrossRef]

110. Schulterbrandt Gragg, R.; Anandhi, A.; Jiru, M.; Usher, K.M. A Conceptualization of the Urban Food-Energy-Water Nexus Sustainability Paradigm: Modeling From Theory to Practice. Front. Environ. Sci. 2018, 6, 133. [CrossRef]

111. Wang, Q.; Li, S.; He, G.; Li, R.; Wang, X. Evaluating sustainability of water-energy-food (WEF) nexus using an improved matter-element extension model: A case study of China. J. Clean. Prod. 2018, 202, 1097-1106. [CrossRef]

112. Berardy, A.; Chester, M. V Climate change vulnerability in the food, energy, and water nexus: Concerns for agricultural production in Arizona and its urban export supply. Environ. Res. Lett. 2017, 12, 035004. [CrossRef]

113. Al-Ansari, T.; Korre, A.; Nie, Z.; Shah, N. Development of a Life Cycle Assessment Model for the Analysis of the Energy, Water and Food Nexus. In Proceedings of the 24th European Symposium on Computer Aided Process Engineering (ESCAPE); Klemes, J., Varbanov, P., Liew, P., Eds.; Elsevier Science BV: Amsterdam, The Netherlands, 2014; pp. 1039-1044.

114. Laso, J.; Margallo, M.; García-Herrero, I.; Fullana, P.; Bala, A.; Gazulla, C.; Polettini, A.; Kahhat, R.; Vázquez-Rowe, I.; Irabien, A.; et al. Combined application of Life Cycle Assessment and linear programming to evaluate food waste-to-food strategies: Seeking for answers in the nexus approach. Waste Manag. 2018, 80, 186-197. [CrossRef]

115. Subedi, R.; Karki, M.; Panday, D. Food System and Water-Energy-Biodiversity Nexus in Nepal: A Review. Agronomy 2020, 10, 1129. [CrossRef]

116. Mukuve, F.M.; Fenner, R.A. Scale variability of water, land, and energy resource interactions and their influence on the food system in Uganda. Sustain. Prod. Consum. 2015, 2, 79-95. [CrossRef]

117. Mukuve, F.M.; Fenner, R.A. The influence of water, land, energy and soil-nutrient resource interactions on the food system in Uganda. Food Policy 2015, 51, 24-37. [CrossRef]

118. Wright, C.; Østergård, H. Renewability and emergy footprint at different spatial scales for innovative food systems in Europe. Ecol. Indic. 2016, 62, 220-227. [CrossRef]

119. Duro, J.A.; Lauk, C.; Kastner, T.; Erb, K.-H.; Haberl, H. Global inequalities in food consumption, cropland demand and land-use efficiency: A decomposition analysis. Glob. Environ. Chang. 2020, 64, 102124. [CrossRef]

120. Pellegrini, P.; Fernández, R.J. Crop intensification, land use, and on-farm energy-use efficiency during the worldwide spread of the green revolution. Proc. Natl. Acad. Sci. USA 2018, 115, 2335-2340. [CrossRef]

121. Godfray, H.C.J. The debate over sustainable intensification. Food Secur. 2015, 7, 199-208. [CrossRef]

122. Kuyper, T.W.; Struik, P.C. Epilogue: Global food security, rhetoric, and the sustainable intensification debate. Curr. Opin. Environ. Sustain. 2014, 8, 71-79. [CrossRef]

123. El Bilali, H.; Callenius, C.; Strassner, C.; Probst, L.; Hauser, M.; Wurzinger, M.; Melcher, A.; Probst, L. Food and nutrition security and sustainability transitions in food systems. In Food and Energy Security; Smyrniotopoulou, A., Koutsouris, A., Eds.; Wiley Online Library: New York, NY, USA, 2018; p. e00154.

124. MacDonald, G.K.; D'Odorico, P.; Seekell, D.A. Pathways to sustainable intensification through crop water management. Environ. Res. Lett. 2016, 11, 091001. [CrossRef]

125. Rudel, T.K.; Paul, B.; White, D.; Rao, I.M.; Van Der Hoek, R.; Castro, A.; Boval, M.; Lerner, A.; Schneider, L.; Peters, M. LivestockPlus: Forages, sustainable intensification, and food security in the tropics. AMBIO 2015, 44, 685-693. [CrossRef]

126. Davis, K.F.; Gephart, J.A.; Emery, K.A.; Leach, A.M.; Galloway, J.N.; D’Odorico, P. Meeting future food demand with current agricultural resources. Glob. Environ. Chang. 2016, 39, 125-132. [CrossRef]

127. Liang, Y.; Han, A.; Chai, L.; Zhi, H. Using the machine learning method to study the environmental footprints embodied in chinese diet. Int. J. Environ. Res. Public Health 2020, 17, 7349. [CrossRef]

128. Kissinger, M.; Sussmann, C.; Dorward, C.; Mullinix, K. Local or global: A biophysical analysis of a regional food system. Renew. Agric. Food Syst. 2019, 34, 523-533. [CrossRef]

129. Clark, T.P.; Longo, S.B. Examining the effect of economic development, region, and time period on the fisheries footprints of nations (1961-2010). Int. J. Comp. Sociol. 2019, 60, 225-248. [CrossRef]

130. Perryman, M.E.; Schramski, J.R. Evaluating the relationship between natural resource management and agriculture using embodied energy and eco-exergy analyses: A comparative study of nine countries. Ecol. Complex. 2015, 22, 152-161. [CrossRef]

131. Kissinger, M. Approaches for calculating a nation's food ecological footprint-The case of Canada. Ecol. Indic. 2013, 24, 366-374. [CrossRef]

132. Becker, S.; Bouzdine-Chameeva, T.; Jaegler, A. The carbon neutrality principle: A case study in the French spirits sector. J. Clean. Prod. 2020, 274, 122739. [CrossRef] 
133. Cimini, A.; Moresi, M. Product Carbon Footprint: Still a Proper Method to Start Improving the Sustainability of Food and Beverage Enterprises. Ital. J. Food Sci. 2019, 31, 808-826.

134. Pérez Neira, D.; Soler Montiel, M.; Delgado Cabeza, M.; Reigada, A. Energy use and carbon footprint of the tomato production in heated multi-tunnel greenhouses in Almeria within an exporting agri-food system context. Sci. Total Environ. 2018, 628-629, 1627-1636. [CrossRef] [PubMed]

135. Farmery, A.K.; Gardner, C.; Green, B.S.; Jennings, S.; Watson, R.A. Domestic or imported? An assessment of carbon footprints and sustainability of seafood consumed in Australia. Environ. Sci. Policy 2015, 54, 35-43. [CrossRef]

136. Xu, Z.; Sun, D.-W.; Zeng, X.-A.; Liu, D.; Pu, H. Research Developments in Methods to Reduce the Carbon Footprint of the Food System: A Review. Crit. Rev. Food Sci. Nutr. 2015, 55, 1270-1286. [CrossRef]

137. Werner, L.B.; Flysjö, A.; Tholstrup, T. Greenhouse gas emissions of realistic dietary choices in Denmark: The carbon footprint and nutritional value of dairy products. Food Nutr. Res. 2014, 58, 20687. [CrossRef]

138. Aoki, K.; Akai, K. Does the Carbon Footprint Enhance the Sustainability Food Production and Transportation Service System? Real Buying Experiment in Japan. In Advances in Production Management Systems, Sustainable Production and Service Supply Chains, Proceedings of the International Conference on Advances in Production Management Systems (APMS), State College, PA, USA, 9-12 September 2013; Prabhu, V., Taisch, M., Kiritsis, D., Eds.; Springer: Berlin/Heidelberg, Germany, 2013; pp. 18-25.

139. Virtanen, Y.; Kurppa, S.; Saarinen, M.; Katajajuuri, J.-M.; Usva, K.; Mäenpää, I.; Mäkelä, J.; Grönroos, J.; Nissinen, A. Carbon footprint of food-Approaches from national input-output statistics and a LCA of a food portion. J. Clean. Prod. 2011, 19, 1849-1856. [CrossRef]

140. Sokolow, J.; Kennedy, G.; Attwood, S. Managing Crop tradeoffs: A methodology for comparing the water footprint and nutrient density of crops for food system sustainability. J. Clean. Prod. 2019, 225, 913-927. [CrossRef]

141. Konar, M.; Reimer, J.J.; Hussein, Z.; Hanasaki, N. The water footprint of staple crop trade under climate and policy scenarios. Environ. Res. Lett. 2016, 11, 035006. [CrossRef]

142. Jackson, N.; Konar, M.; Hoekstra, A. The Water Footprint of Food Aid. Sustainability 2015, 7, 6435-6456. [CrossRef]

143. Boyer, D.; Sarkar, J.; Ramaswami, A. Diets, Food Miles, and Environmental Sustainability of Urban Food Systems: Analysis of Nine Indian Cities. Earth's Futur. 2019, 7, 911-922. [CrossRef]

144. Pérez Neira, D.; Simón Fernández, X.; Copena Rodríguez, D.; Soler Montiel, M.; Delgado Cabeza, M. Analysis of the transport of imported food in Spain and its contribution to global warming. Renew. Agric. Food Syst. 2016, 31, 37-48. [CrossRef]

145. Robinson, C.; Shirazi, A.; Liu, M.; Dilkina, B. Network Optimization of Food Flows in the US. In Proceedings of the 4th IEEE International Conference on Big Data (Big Data), Washington, DC, USA, 5-8 December 2016; Joshi, J., Karypis, G., Liu, L., Hu, X., Ak, R., Xia, Y., Xu, W., Sato, A., Rachuri, S., Ungar, L., et al., Eds.; IEEE: New York, NY, USA, 2016; pp. $2190-2198$.

146. Cleveland, D.A.; Carruth, A.; Mazaroli, D.N. Operationalizing local food: Goals, actions, and indicators for alternative food systems. Agric. Human Values 2015, 32, 281-297. [CrossRef]

147. Kissinger, M. International trade related food miles-The case of Canada. Food Policy 2012, 37, 171-178. [CrossRef]

148. Coley, D.; Howard, M.; Winter, M. Local food, food miles and carbon emissions: A comparison of farm shop and mass distribution approaches. Food Policy 2009, 34, 150-155. [CrossRef]

149. Timpanaro, G.; Foti, V.T.; Scuderi, A.; Schippa, G.; Branca, F. New food supply chain systems based on a proximity model: The case of an alternative food network in the Catania urban area. Acta Hortic. 2018, 1215, 213-218. [CrossRef]

150. Vittersø, G.; Torjusen, H.; Laitala, K.; Tocco, B.; Biasini, B.; Csillag, P.; de Labarre, M.D.; Lecoeur, J.-L.; Maj, A.; Majewski, E.; et al. Short Food Supply Chains and Their Contributions to Sustainability: Participants' Views and Perceptions from 12 European Cases. Sustainability 2019, 11, 4800. [CrossRef]

151. Schmutz, U.; Kneafsey, M.; Sarrouy Kay, C.; Doernberg, A.; Zasada, I. Sustainability impact assessments of different urban short food supply chains: Examples from London, UK. Renew. Agric. Food Syst. 2018, 33, 518-529. [CrossRef]

152. Mazzocchi, C.; Corsi, S.; Ruggeri, G. The Coexistence of Local and Global Food Supply Chains: The Lombardy Region Case Study. Agriculture 2020, 10, 540. [CrossRef]

153. Blumberg, R.; Leitner, H.; Cadieux, K.V. For food space: Theorizing alternative food networks beyond alterity. J. Polit. Ecol. 2020, 27, 1-22. [CrossRef]

154. Mastronardi, L.; Romagnoli, L.; Mazzocchi, G.; Giaccio, V.; Marino, D. Understanding consumer's motivations and behaviour in alternative food networks. Br. Food J. 2019, 121, 2102-2115. [CrossRef]

155. De Bernardi, P.; Bertello, A.; Venuti, F. Online and On-Site Interactions within Alternative Food Networks: Sustainability Impact of Knowledge-Sharing Practices. Sustainability 2019, 11, 1457. [CrossRef]

156. Chico, D.; Aldaya, M.M.; Flachsbarth, I.; Garrido, A. Virtual water trade, food security and sustainability: Lessons from Latin America and Spain. In Proceedings of the 6th Botin Water Workshop, Madrid, Spain, 14-15 November 2012; MartinezSantos, P., Aldaya, M., Llamas, M., Eds.; CRC Press-Taylor \& Francis Group: Boca Rato, FL, USA, 2014; pp. $79-98$.

157. Ridoutt, B.G.; Sanguansri, P.; Nolan, M.; Marks, N. Meat consumption and water scarcity: Beware of generalizations. J. Clean. Prod. 2012, 28, 127-133. [CrossRef]

158. Garnier, J.; Lassaletta, L.; Billen, G.; Romero, E.; Grizzetti, B.; Némery, J.; Le, T.P.Q.; Pistocchi, C.; Aissa-Grouz, N.; Luu, T.N.M.; et al. Phosphorus budget in the water-agro-food system at nested scales in two contrasted regions of the world (ASEAN-8 and EU-27). Global Biogeochem. Cycles 2015, 29, 1348-1368. [CrossRef] 
159. Westhoek, H.; Lesschen, J.P.; Rood, T.; Wagner, S.; De Marco, A.; Murphy-Bokern, D.; Leip, A.; van Grinsven, H.; Sutton, M.A.; Oenema, O. Food choices, health and environment: Effects of cutting Europe's meat and dairy intake. Glob. Environ. Chang. 2014, 26, 196-205. [CrossRef]

160. Metson, G.S.; Cordell, D.; Ridoutt, B. Potential Impact of Dietary Choices on Phosphorus Recycling and Global Phosphorus Footprints: The Case of the Average Australian City. Front. Nutr. 2016, 3, 35. [CrossRef] [PubMed]

161. Wegren, S.; Trotsuk, I. Is industrial agriculture sustainable during climate change and ecological threats? J. Econ. Sociol. 2020, 21, 12-38. [CrossRef]

162. Tortorella, M.M.; Di Leo, S.; Cosmi, C.; Fortes, P.; Viccaro, M.; Cozzi, M.; Pietrapertosa, F.; Salvia, M.; Romano, S. A Methodological Integrated Approach to Analyse Climate Change Effects in Agri-Food Sector: The TIMES Water-Energy-Food Module. Int. J. Environ. Res. Public Health 2020, 17, 7703. [CrossRef]

163. Ricci, E.C.; Banterle, A. Do major climate change-related public events have an impact on consumer choices? Renew. Sustain. Energy Rev. 2020, 126, 109793. [CrossRef]

164. Baldos, U.L.C.; Fuglie, K.O.; Hertel, T.W. The research cost of adapting agriculture to climate change: A global analysis to 2050. Agric. Econ. 2020, 51, 207-220. [CrossRef]

165. Kemper, J.A.; Ballantine, P.W. Targeting the structural environment at multiple social levels for systemic change. J. Soc. Mark. 2019, 10, 38-53. [CrossRef]

166. Macdiarmid, J.I.; Whybrow, S. Nutrition from a climate change perspective. Proc. Nutr. Soc. 2019, 78, 380-387. [CrossRef]

167. Ritchie, H.; Reay, D.S.; Higgins, P. The impact of global dietary guidelines on climate change. Glob. Environ. Chang. 2018, 49, 46-55. [CrossRef]

168. Ritchie, H.; Reay, D.S.; Higgins, P. Potential of Meat Substitutes for Climate Change Mitigation and Improved Human Health in High-Income Markets. Front. Sustain. Food Syst. 2018, 2, 16. [CrossRef]

169. Li, H.; Wu, T.; Wang, X.; Qi, Y. The Greenhouse Gas Footprint of China's Food System: An Analysis of Recent Trends and Future Scenarios. J. Ind. Ecol. 2016, 20, 803-817. [CrossRef]

170. Mesquita, P.D.S.; Bursztyn, M. Alimentação e mudanças climáticas: Percepções e o potencial de mudanças comportamentais em prol da mitigação. Desenvolv. Meio Ambient. 2018, 49, 1-16. [CrossRef]

171. Mohareb, E.A.; Heller, M.C.; Guthrie, P.M. Cities' Role in Mitigating United States Food System Greenhouse Gas Emissions. Environ. Sci. Technol. 2018, 52, 5545-5554. [CrossRef]

172. Torquebiau, E.; Rosenzweig, C.; Chatrchyan, A.M.; Andrieu, N.; Khosla, R. Identifying Climate-smart agriculture research needs. Cah. Agric. 2018, 27, 26001. [CrossRef]

173. Yu, Q.; Wu, W.; Yang, P.; Li, Z.; Xiong, W.; Tang, H. Proposing an interdisciplinary and cross-scale framework for global change and food security researches. Agric. Ecosyst. Environ. 2012, 156, 57-71. [CrossRef]

174. Spring, Ú.O. Climate-Smart Agriculture and A Sustainable Food System for A Sustainable-Engendered Peace; Springer: Cham, Switzerland, 2019; pp. 95-123.

175. Campbell, A. Australian rangelands science-A strategic national asset. Rangel. J. 2020, 42, 261. [CrossRef]

176. Leclère, D.; Obersteiner, M.; Barrett, M.; Butchart, S.H.M.; Chaudhary, A.; De Palma, A.; DeClerck, F.A.J.; Di Marco, M.; Doelman, J.C.; Dürauer, M.; et al. Bending the curve of terrestrial biodiversity needs an integrated strategy. Nature 2020, 585, 551-556. [CrossRef]

177. Ridoutt, B.; Navarro Garcia, J. Cropland footprints from the perspective of productive land scarcity, malnutrition-related health impacts and biodiversity loss. J. Clean. Prod. 2020, 260, 121150. [CrossRef]

178. Crenna, E.; Sinkko, T.; Sala, S. Biodiversity impacts due to food consumption in Europe. J. Clean. Prod. 2019, $227,378-391$. [CrossRef]

179. Dudley, N.; Attwood, S.J.; Goulson, D.; Jarvis, D.; Bharucha, Z.P.; Pretty, J. How should conservationists respond to pesticides as a driver of biodiversity loss in agroecosystems? Biol. Conserv. 2017, 209, 449-453. [CrossRef]

180. Aguilar, J.; Gramig, G.G.; Hendrickson, J.R.; Archer, D.W.; Forcella, F.; Liebig, M.A. Crop Species Diversity Changes in the United States: 1978-2012. PLoS ONE 2015, 10, e0136580. [CrossRef]

181. Mulesa, T.H.; Westengen, O.T. Against the grain? A historical institutional analysis of access governance of plant genetic resources for food and agriculture in Ethiopia. J. World Intellect. Prop. 2020, 23, 82-120. [CrossRef]

182. Lombardi, G.V.; Atzori, R.; Acciaioli, A.; Giannetti, B.; Parrini, S.; Liu, G. Agricultural landscape modification and land food footprint from 1970 to 2010: A case study of Sardinia, Italy. J. Clean. Prod. 2019, 239, 118097. [CrossRef]

183. Weerasekara, P.C.; Withanachchi, C.R.; Ginigaddara, G.A.S.; Ploeger, A. Understanding dietary diversity, dietary practices and changes in food patterns in marginalised societies in Sri Lanka. Foods 2020, 9, 1659. [CrossRef]

184. Omotayo, A.O. Data on the agricultural household's dietary diversity and health in the South West geopolitical zone of Nigeria. Data Brief 2020, 30, 105413. [CrossRef]

185. Ng'endo, M.; Keding, G.B.; Bhagwat, S.; Kehlenbeck, K. Variability of On-Farm Food Plant Diversity and Its Contribution to Food Security: A Case Study of Smallholder Farming Households in Western Kenya. Agroecol. Sustain. Food Syst. 2015, 39, 1071-1103. [CrossRef]

186. Luckett, B.G.; DeClerck, F.A.; Fanzo, J.; Mundorf, A.R.; Rose, D. Application of the Nutrition Functional Diversity indicator to assess food system contributions to dietary diversity and sustainable diets of Malawian households. Public Health Nutr. 2015, 18, 2479-2487. [CrossRef] [PubMed] 
187. Mabhaudhi, T.; Chibarabada, T.; Chimonyo, V.; Murugani, V.; Pereira, L.; Sobratee, N.; Govender, L.; Slotow, R.; Modi, A. Mainstreaming underutilized indigenous and traditional crops into food systems: A South African perspective. Sustainability 2018, 11, 172. [CrossRef]

188. Solberg, S.Ø.; Seta-Waken, P.; Paul, T.; Palaniappan, G.; Iramu, E. Patterns in the conservation and use of traditional vegetables from the New Guinean biodiversity hotspot. Agroecol. Sustain. Food Syst. 2018, 42, 1079-1091. [CrossRef]

189. Borelli, T.; Hunter, D.; Padulosi, S.; Amaya, N.; Meldrum, G.; de Oliveira Beltrame, D.M.; Samarasinghe, G.; Wasike, V.W.; Güner, B.; Tan, A.; et al. Local Solutions for Sustainable Food Systems: The Contribution of Orphan Crops and Wild Edible Species. Agronomy 2020, 10, 231. [CrossRef]

190. Migliorini, P.; Wezel, A. Converging and diverging principles and practices of organic agriculture regulations and agroecology. A review. Agron. Sustain. Dev. 2017, 37, 63. [CrossRef]

191. Krupnik, T.; McLaughlin, S.; Altieri, M.A. Shifting the paradigm: Alternatives to the fatal harvest of industrial agricultureReflections on the past and future of farming by California agricultural students. J. Food Agric. Environ. 2003, 1, $355-357$.

192. Getz, C.; Brown, S.; Shreck, A. Class Politics and Agricultural Exceptionalism in California's Organic Agriculture Movement. Polit. Soc. 2008, 36, 478-507. [CrossRef]

193. Metelerkamp, L.; Biggs, R.; Drimie, S. Learning for transitions: A niche perspective. Ecol. Soc. 2020, 25, art14. [CrossRef]

194. Röös, E.; Mie, A.; Wivstad, M.; Salomon, E.; Johansson, B.; Gunnarsson, S.; Wallenbeck, A.; Hoffmann, R.; Nilsson, U.; Sundberg, C.; et al. Risks and opportunities of increasing yields in organic farming. A review. Agron. Sustain. Dev. 2018, 38, 14. [CrossRef]

195. Van Hulst, F.; Ellis, R.; Prager, K.; Msika, J. Using co-constructed mental models to understand stakeholder perspectives on agro-ecology. Int. J. Agric. Sustain. 2020, 18, 172-195. [CrossRef]

196. Chable, V.; Nuijten, E.; Costanzo, A.; Goldringer, I.; Bocci, R.; Oehen, B.; Rey, F.; Fasoula, D.; Feher, J.; Keskitalo, M.; et al. Embedding cultivated diversity in society for agro-ecological transition. Sustainability 2020, 12, 784. [CrossRef]

197. Reeve, J.R.; Carpenter-Boggs, L.; Sehmsdorf, H. Sustainable agriculture: A case study of a small Lopez Island farm. Agric. Syst. 2011, 104, 572-579. [CrossRef]

198. Bisht, I.S.; Rana, J.C.; Pal Ahlawat, S. The Future of Smallholder Farming in India: Some Sustainability Considerations. Sustainability 2020, 12, 3751. [CrossRef]

199. Vastola, A.; Zdruli, P.; D’Amico, M.; Pappalardo, G.; Viccaro, M.; Di Napoli, F.; Cozzi, M.; Romano, S. A comparative multidimensional evaluation of conservation agriculture systems: A case study from a Mediterranean area of Southern Italy. Land Use Policy 2017, 68, 326-333. [CrossRef]

200. Francis, C.; Lieblein, G.; Gliessman, S.; Breland, T.A.; Creamer, N.; Harwood, R.; Salomonsson, L.; Helenius, J.; Rickerl, D.; Salvador, R.; et al. Agroecology: The Ecology of Food Systems. J. Sustain. Agric. 2003, 22, 99-118. [CrossRef]

201. Gliessman, S. A Voice for Sustainability from Latin America. J. Sustain. Agric. 2012, 36, 1-2. [CrossRef]

202. Gliessman, S. Agroecology: Growing the Roots of Resistance. Agroecol. Sustain. Food Syst. 2013, 37, 19-31. [CrossRef]

203. Ringling, K.M.; Marquart, L.F. Intersection of Diet, Health, and Environment: Land Grant Universities' Role in Creating Platforms for Sustainable Food Systems. Front. Sustain. Food Syst. 2020, 4, 70. [CrossRef]

204. Mylan, J. Sustainable Consumption in Everyday Life: A Qualitative Study of UK Consumer Experiences of Meat Reduction. Sustainability 2018, 10, 2307. [CrossRef]

205. Sabaté, J.; Soret, S. Sustainability of plant-based diets: Back to the future. Am. J. Clin. Nutr. 2014, 100, 476S-482S. [CrossRef]

206. Vanham, D.; del Pozo, S.; Pekcan, A.G.; Keinan-Boker, L.; Trichopoulou, A.; Gawlik, B.M. Water consumption related to different diets in Mediterranean cities. Sci. Total Environ. 2016, 573, 96-105. [CrossRef]

207. Echeverría, G.; Tiboni, O.; Berkowitz, L.; Pinto, V.; Samith, B.; von Schultzendorff, A.; Pedrals, N.; Bitran, M.; Ruini, C.; Ryff, C.D.; et al. Mediterranean Lifestyle to Promote Physical, Mental, and Environmental Health: The Case of Chile. Int. J. Environ. Res. Public Health 2020, 17, 8482. [CrossRef] [PubMed]

208. Kim, D.; Parajuli, R.; Thoma, G.J. Life Cycle Assessment of Dietary Patterns in the United States: A Full Food Supply Chain Perspective. Sustainability 2020, 12, 1586. [CrossRef]

209. Boyer, D.; Ramaswami, A. Comparing urban food system characteristics and actions in US and Indian cities from a multienvironmental impact perspective: Toward a streamlined approach. J. Ind. Ecol. 2020, 24, 841-854. [CrossRef]

210. Rehkamp, S.; Canning, P. Measuring Embodied Blue Water in American Diets: An EIO Supply Chain Approach. Ecol. Econ. 2018, 147, 179-188. [CrossRef]

211. Goldstein, B.; Hansen, S.F.; Gjerris, M.; Laurent, A.; Birkved, M. Ethical aspects of life cycle assessments of diets. Food Policy 2016, 59, 139-151. [CrossRef]

212. Challies, E.R.T.; Murray, W.E. The Interaction of Global Value Chains and Rural Livelihoods: The Case of Smallholder Raspberry Growers in Chile. J. Agrar. Chang. 2011, 11, 29-59. [CrossRef]

213. Butler, J.R.A.; Rochester, W.; Skewes, T.D.; Wise, R.M.; Bohensky, E.L.; Katzfey, J.; Kirono, D.G.C.; Peterson, N.; Suadnya, W.; Yanuartati, Y.; et al. How Feasible Is the Scaling-Out of Livelihood and Food System Adaptation in Asia-Pacific Islands? Front. Sustain. Food Syst. 2020, 4, 43. [CrossRef]

214. Diehl, J.A. Growing for Sydney: Exploring the urban food system through farmers' social networks. Sustainability 2020, $12,3346$. [CrossRef] 
215. Negra, C.; Remans, R.; Attwood, S.; Jones, S.; Werneck, F.; Smith, A. Sustainable agri-food investments require multi-sector co-development of decision tools. Ecol. Indic. 2020, 110, 105851. [CrossRef]

216. Clapp, J. The rise of financial investment and common ownership in global agrifood firms. Rev. Int. Polit. Econ. 2019, 26, 604-629. [CrossRef]

217. Galli, F.; Hebinck, A.; Carroll, B. Addressing food poverty in systems: Governance of food assistance in three European countries. Food Secur. 2018, 10, 1353-1370. [CrossRef]

218. Stein, K.; Mirosa, M.; Carter, L. Māori women leading local sustainable food systems. Altern. Int. J. Indig. Peoples 2018, 14, 147-155. [CrossRef]

219. Hebinck, A.; Galli, F.; Arcuri, S.; Carroll, B.; O'Connor, D.; Oostindie, H. Capturing change in European food assistance practices: A transformative social innovation perspective. Local Environ. 2018, 23, 398-413. [CrossRef]

220. Bounie, D.; Arcot, J.; Cole, M.; Egal, F.; Juliano, P.; Mejia, C.; Rosa, D.; Sellahewa, J. The role of food science and technology in humanitarian response. Trends Food Sci. Technol. 2020, 103, 367-375. [CrossRef]

221. Kraus, S. San Jose Food Works Study: Demonstrating the Economics of Local Food Systems Toolkit Methodology. J. Agric. Food Syst. Community Dev. 2019, 8, 119-135. [CrossRef]

222. Kristensen, D.K.; Kjeldsen, C.; Thorsøe, M.H. Enabling Sustainable Agro-Food Futures: Exploring Fault Lines and Synergies Between the Integrated Territorial Paradigm, Rural Eco-Economy and Circular Economy. J. Agric. Environ. Ethics 2016, 29, 749-765. [CrossRef]

223. Mundler, P.; Laughrea, S. The contributions of short food supply chains to territorial development: A study of three Quebec territories. J. Rural Stud. 2016, 45, 218-229. [CrossRef]

224. Allaert, K. Closing the loop: How food localisation contributes to the sustainability of settlements. In Proceedings of the 51st ISOCARP Congress, Rotterdam, The Netherlands, 19-23 October 2015; Ryser, J., Ed.; ISOCARP: Hague, The Netherlands, 2015.

225. Inman, P. Regional Food systems as Engines for Sustainable Economies: How do universities engage? Soc. Altern. 2015, 34, 39-46.

226. Kelly, C.; Schulschenk, J. Assessing the vulnerability of Stellenbosch's food system and possibilities for a local food economy. Dev. South. Afr. 2011, 28, 563-578. [CrossRef]

227. Kniuksta, B.; Caplikas, J. The Role of Alternative Use of Agricultural Products in the Eco-localization of Economy. In Proceedings of the 5th International Scientific Conference on Rural Development in Global Changes, Kaunas, Lithuania, 24-25 November 2011; Aleksandras Stulginskis University: Akademija, Lithuania, 2011; pp. 124-130.

228. Derunova, E.; Kireeva, N.; Pruschak, O. Inclusive Development of The Agri-Food System as a Driver for Sustainable Growth in the Region's Economy. Sci. Pap. Manag. Econ. Eng. Agric. Rural Dev. 2019, 19, 165-173.

229. Jongerden, J.; Wolters, W.; Dijkxhoorn, Y.; Gür, F.; Öztürk, M. The Politics of Agricultural Development in Iraq and the Kurdistan Region in Iraq (KRI). Sustainability 2019, 11, 5874. [CrossRef]

230. Fernandez-Mena, H.; MacDonald, G.K.; Pellerin, S.; Nesme, T. Co-benefits and Trade-Offs From Agro-Food System Redesign for Circularity: A Case Study With the FAN Agent-Based Model. Front. Sustain. Food Syst. 2020, 4, 41. [CrossRef]

231. Lu, T.; Halog, A. Towards better life cycle assessment and circular economy: On recent studies on interrelationships among environmental sustainability, food systems and diet. Int. J. Sustain. Dev. World Ecol. 2020, 27, 515-523. [CrossRef]

232. Jurgilevich, A.; Birge, T.; Kentala-Lehtonen, J.; Korhonen-Kurki, K.; Pietikäinen, J.; Saikku, L.; Schösler, H. Transition towards circular economy in the food system. Sustainability 2016, 8, 69. [CrossRef]

233. Viola, I.; Pontrandolfi, A.; Manelli, A. The Employment Crisis and Green Orientation in Agriculture: New Educational Models. Agric. Agric. Sci. Procedia 2016, 8, 560-565. [CrossRef]

234. Sarkar, S.F.; Poon, J.S.; Lepage, E.; Bilecki, L.; Girard, B. Enabling a sustainable and prosperous future through science and innovation in the bioeconomy at Agriculture and Agri-Food Canada. New Biotechnol. 2018, 40, 70-75. [CrossRef]

235. Ben Hassen, T.; El Bilali, H.; Al-Maadeed, M. Agri-Food Markets in Qatar: Drivers, Trends, and Policy Responses. Sustainability 2020, 12, 3643. [CrossRef]

236. Borsellino, V.; Schimmenti, E.; El Bilali, H. Agri-Food Markets towards Sustainable Patterns. Sustainability 2020, $12,2193$. [CrossRef]

237. Audet, R.; Lefèvre, S.; Brisebois, É.; El-Jed, M. Structuring Tensions and Key Relations of Montreal Seasonal Food Markets in the Sustainability Transition of the Agri-Food Sector. Sustainability 2017, 9, 320. [CrossRef]

238. Yach, D. The role of business in addressing the long-term implications of the current food crisis. Global. Health $2008,4,12$. [CrossRef]

239. Caraher, M.; Coveney, J. Public health nutrition and food policy. Public Health Nutr. 2004, 7, 591-598. [CrossRef]

240. Elmes, M.B. Economic Inequality, Food Insecurity, and the Erosion of Equality of Capabilities in the United States. Bus. Soc. 2018, 57, 1045-1074. [CrossRef]

241. Longo, S.B.; Clark, B. The Commodification of Bluefin Tuna: The Historical Transformation of the Mediterranean Fishery. J. Agrar. Chang. 2012, 12, 204-226. [CrossRef]

242. Vivero-Pol, J.L. The idea of food as commons or commodity in academia. A systematic review of English scholarly texts. J. Rural Stud. 2017, 53, 182-201. [CrossRef]

243. Vivero-Pol, J. Food as Commons or Commodity? Exploring the Links between Normative Valuations and Agency in Food Transition. Sustainability 2017, 9, 442. [CrossRef] 
244. Rundgren, G. Food: From Commodity to Commons. J. Agric. Environ. Ethics 2016, 29, 103-121. [CrossRef]

245. Calisto Friant, M. Comercio justo, seguridad alimentaria y globalización: Construyendo sistemas alimentarios alternativos. Íconos Rev. Ciencias Soc. 2016, 215. [CrossRef]

246. Duram, L.; Mead, A. Exploring linkages between Consumer Food Co-operatives and Domestic Fair Trade in the United States. Renew. Agric. Food Syst. 2014, 29, 151-160. [CrossRef]

247. Hedberg, R.C.; Zimmerer, K.S. What's the market got to do with it? Social-ecological embeddedness and environmental practices in a local food system initiative. Geoforum 2020, 110, 35-45. [CrossRef]

248. O'Kane, G.; Wijaya, S.Y. Contribution of Farmers' Markets to More Socially Sustainable Food Systems: A Pilot Study of a Farmers' Market in the Australian Capital Territory (ACT), Australia. Agroecol. Sustain. Food Syst. 2015, 39, 1124-1153. [CrossRef]

249. Milestad, R.; Westberg, L.; Geber, U.; Björklund, J. Enhancing adaptive capacity in food systems: Learning at farmers' markets in Sweden. Ecol. Soc. 2010, 15, 29. [CrossRef]

250. Zurek, M.; Hebinck, A.; Leip, A.; Vervoort, J.; Kuiper, M.; Garrone, M.; Havlík, P.; Heckelei, T.; Hornborg, S.; Ingram, J.; et al. Assessing Sustainable Food and Nutrition Security of the EU Food System-An Integrated Approach. Sustainability 2018, 10, 4271. [CrossRef]

251. Coleman, P.; Gultig, J.; Emanuel, B.; Gee, M.; Orpana, H. Status report-FoodReach Toronto: Lowering food costs for social agencies and community groups. Health Promot. Chronic Dis. Prev. Can. 2018, 38, 23-28. [CrossRef] [PubMed]

252. Pinstrup-Andersen, P. Contemporary food policy challenges and opportunities. Aust. J. Agric. Resour. Econ. 2014, 58, 504-518. [CrossRef]

253. Drewnowski, A.; Finley, J.; Hess, J.M.; Ingram, J.; Miller, G.; Peters, C. Toward Healthy Diets from Sustainable Food Systems. Curr. Dev. Nutr. 2020, 4, nzaa083. [CrossRef]

254. Pretty, J.N.; Ball, A.S.; Lang, T.; Morison, J.I.L. Farm costs and food miles: An assessment of the full cost of the UK weekly food basket. Food Policy 2005, 30, 67-72. [CrossRef]

255. O'Kane, G. What is the real cost of our food? Implications for the environment, society and public health nutrition. Public Health Nutr. 2012. [CrossRef]

256. Pérez Neira, D. Energy sustainability of Ecuadorian cacao export and its contribution to climate change. A case study through product life cycle assessment. J. Clean. Prod. 2016, 112, 2560-2568. [CrossRef]

257. Infante Amate, J.; González de Molina, M. 'Sustainable de-growth' in agriculture and food: An agro-ecological perspective on Spain's agri-food system (year 2000). J. Clean. Prod. 2013, 38, 27-35. [CrossRef]

258. Coveney, J. Food security and sustainability: Are we selling ourselves short? Asia Pac. J. Clin. Nutr. 2000, 9, S97-S100. [CrossRef]

259. Gaddis, J.; Coplen, A.K. Reorganizing School Lunch for a More Just and Sustainable Food System in the US. Fem. Econ. 2018, 24, 89-112. [CrossRef]

260. Van Grinsven, H.J.M.; Erisman, J.W.; de Vries, W.; Westhoek, H. Potential of extensification of European agriculture for a more sustainable food system, focusing on nitrogen. Environ. Res. Lett. 2015, 10, 025002. [CrossRef]

261. Smaal, S.A.L.; Dessein, J.; Wind, B.J.; Rogge, E. Social justice-oriented narratives in European urban food strategies: Bringing forward redistribution, recognition and representation. Agric. Human Values 2020. [CrossRef]

262. Thompson, M.S.; Cochrane, A.; Hopma, J. Democratising food: The case for a deliberative approach. Rev. Int. Stud. 2020, 46, 435-455. [CrossRef]

263. Nicol, P.; Taherzadeh, A. Working Co-operatively for Sustainable and Just Food System Transformation. Sustainability 2020, 12, 2816. [CrossRef]

264. Maughan, C.; Anderson, C.; Kneafsey, M. A Five-Point Framework for Reading for Social Justice: A Case Study of Food Policy Discourse in the Context of Brexit Britain. J. Agric. Food Syst. Community Dev. 2020, 9, 281-300. [CrossRef]

265. Smith, B. Building Emancipatory Food Power: Freedom Farms, Rocky Acres and the Struggle for Food Justice. J. Agric. Food Syst. Community Dev. 2019, 8, 33-43. [CrossRef]

266. Cachelin, A.; Ivkovich, L.; Jensen, P.; Neild, M. Leveraging foodways for health and justice. Local Environ. 2019, $24,417-427$. [CrossRef]

267. Glennie, C.; Alkon, A.H. Food justice: Cultivating the field. Environ. Res. Lett. 2018, 13, 073003. [CrossRef]

268. Gaechter, L.; Porter, C. "Ultimately about Dignity": Social Movement Frames Used by Collaborators in the Food Dignity Action-Research Project. J. Agric. Food Syst. Community Dev. 2018, 8, 147-166. [CrossRef]

269. Porter, C. Fostering Formal Learning in the Food Dignity Project. J. Agric. Food Syst. Community Dev. 2018, 8, 213-219. [CrossRef]

270. Lohest, F.; Bauler, T.; Sureau, S.; Van Mol, J.; Achten, W.M.J. Linking Food Democracy and Sustainability on the Ground: Learnings from the Study of Three Alternative Food Networks in Brussels. Polit. Gov. 2019, 7, 21-31. [CrossRef]

271. Baldy, J.; Kruse, S. Food Democracy from the Top Down? State-Driven Participation Processes for Local Food System Transformations towards Sustainability. Polit. Gov. 2019, 7, 68-80. [CrossRef]

272. Fernandez-Wulff, P. Collective Agency in the Making: How Social Innovations in the Food System Practice Democracy beyond Consumption. Polit. Gov. 2019, 7, 81-93. [CrossRef]

273. Gumbert, T. Anti-Democratic Tenets? Behavioural-Economic Imaginaries of a Future Food System. Polit. Gov. 2019, 7, 94-104. [CrossRef]

274. Bornemann, B.; Weiland, S. Empowering People-Democratising the Food system? Exploring the Democratic Potential of Food-Related Empowerment Forms. Polit. Gov. 2019, 7, 105-118. [CrossRef] 
275. Prost, S. Food Democracy for All? Developing a Food Hub in the Context of Socio-Economic Deprivation. Polit. Gov. 2019, 7, 142-153. [CrossRef]

276. Chiffoleau, Y.; Millet-Amrani, S.; Canard, A. From Short Food Supply Chains to Sustainable Agriculture in Urban Food Systems: Food Democracy as a Vector of Transition. Agriculture 2016, 6, 57. [CrossRef]

277. Meek, D.; Tarlau, R. Critical food systems education (CFSE): Educating for food sovereignty. Agroecol. Sustain. Food Syst. 2016, 40, 237-260. [CrossRef]

278. Jones, A.D.; Fink Shapiro, L.; Wilson, M.L. Assessing the Potential and Limitations of Leveraging Food Sovereignty to Improve Human Health. Front. Public Health 2015, 3, 263. [CrossRef]

279. Bernstein, H. Food sovereignty via the 'peasant way': A sceptical view. J. Peasant Stud. 2014, 41, 1031-1063. [CrossRef]

280. Desmarais, A.A.; Wittman, H. Farmers, foodies and First Nations: Getting to food sovereignty in Canada. J. Peasant Stud. 2014, 41, 1153-1173. [CrossRef]

281. Lutz, J.; Schachinger, J. Do local food networks foster socio-ecological transitions towards food sovereignty? Learning from real place experiences. Sustainability 2013, 5, 4778-4796. [CrossRef]

282. Boyer, J. Food security, food sovereignty, and local challenges for transnational agrarian movements: The Honduras case. J. Peasant. Stud. 2010, 37, 319-351. [CrossRef]

283. Ruiz-Almeida, A.; Rivera-Ferre, M.G. Internationally-based indicators to measure Agri-food systems sustainability using food sovereignty as a conceptual framework. Food Secur. 2019, 11, 1321-1337. [CrossRef]

284. Jacobi, J.; Llanque, A. "When We Stand up, They Have to Negotiate with Us": Power Relations in and between an Agroindustrial and an Indigenous Food System in Bolivia. Sustainability 2018, 10, 4001. [CrossRef]

285. Drimie, S.; Hamann, R.; Manderson, A.P.; Mlondobozi, N. Creating transformative spaces for dialogue and action: Reflecting on the experience of the Southern Africa Food Lab. Ecol. Soc. 2018, 23, art2. [CrossRef]

286. Anderson, M.D. Rights-based food systems and the goals of food systems reform. Agric. Human Values 2008, 25, 593-608. [CrossRef]

287. Bellows, A.C. A systems-based human rights approach to a national food plan in the USA. Renew. Agric. Food Syst. 2020, 35, 442-444. [CrossRef]

288. Yoon, B.-S.; Song, W. Addressing the Agri-Food Crisis in Korea: Implications of Food Sovereignty and the UN Declaration on the Rights of Peasants. Korea J. 2018, 58, 143-166. [CrossRef]

289. Shannon, K.L.; Kim, B.F.; McKenzie, S.E.; Lawrence, R.S. Food System Policy, Public Health, and Human Rights in the United States. Annu. Rev. Public Health 2015, 36, 151-173. [CrossRef]

290. Weiler, A.; Levkoe, C.; Young, C. Cultivating Equitable Ground: Community-based Participatory Research To Connect Food Movements with Migrant Farmworkers. J. Agric. Food Syst. Community Dev. 2016, 6, 73-87. [CrossRef]

291. Escajedo San-Epifanio, L. Challenging Food Governance Models: Analyzing the Food Citizen and the Emerging Food Constitutionalism from an EU Perspective. J. Agric. Environ. Ethics 2015, 28, 435-454. [CrossRef]

292. Jacobi, J.; Mukhovi, S.; Llanque, A.; Giger, M.; Bessa, A.; Golay, C.; Ifejika Speranza, C.; Mwangi, V.; Augstburger, H.; Buergi-Bonanomi, E.; et al. A new understanding and evaluation of food sustainability in six different food systems in Kenya and Bolivia. Sci. Rep. 2020, 10, 19145. [CrossRef]

293. Allievi, F.; Vinnari, M.; Luukkanen, J. Meat consumption and production-Analysis of efficiency, sufficiency and consistency of global trends. J. Clean. Prod. 2015, 92, 142-151. [CrossRef]

294. Evans, B.; Johnson, H. Responding to the problem of 'food security' in animal cruelty policy debates: Building alliances between animal-centred and human-centred work on food system issues. Agric. Hum. Values 2020, 37, 161-174. [CrossRef]

295. Wilkinson, J. Food security and the global agrifood system: Ethical issues in historical and sociological perspective. Glob. Food Sec. 2015, 7, 9-14. [CrossRef]

296. Chiu, T.H.T.; Lin, C.-L. Ethical management of food systems: Plant based diet as a holistic approach. Asia Pac. J. Clin. Nutr. 2009, $18,647-653$.

297. Bui, S.; Costa, I.; De Schutter, O.; Dedeurwaerdere, T.; Hudon, M.; Feyereisen, M. Systemic ethics and inclusive governance: Two key prerequisites for sustainability transitions of agri-food systems. Agric. Human Values 2019, 36, 277-288. [CrossRef]

298. Maye, D.; Kirwan, J.; Brunori, G. Ethics and responsibilisation in agri-food governance: The single-use plastics debate and strategies to introduce reusable coffee cups in UK retail chains. Agric. Hum. Values 2019, 36, 301-312. [CrossRef]

299. Sharpe, R.; Barling, D. 'The right thing to do': Ethical motives in the interpretation of social sustainability in the UK's conventional food supply. Agric. Hum. Values 2019, 36, 329-340. [CrossRef]

300. Tisenkopfs, T.; Kilis, E.; Grivins, M.; Adamsone-Fiskovica, A. Whose ethics and for whom? Dealing with ethical disputes in agri-food governance. Agric. Hum. Values 2019, 36, 353-364. [CrossRef]

301. Rodak, O. Hashtag hijacking and crowdsourcing transparency: Social media affordances and the governance of farm animal protection. Agric. Hum. Values 2020, 37, 281-294. [CrossRef]

302. Ferreira, G. Strategies for Innovation, Valorization and Marketing of Uruguayan Meat within the Framework of Food Security and Animal Welfare. In Proceedings of the International Workshop on New Opportunities for Dairy and Dual Purpose Ruminant Systems in Latin America, Ixtapan de la Sal, Mexico, 28-30 June 2006; Ortega, O., Jal, A., Santos, R., Mould, F., Eds.; Universidad Autonoma del Estado de Mexico: Toluca, Mexico, 2008; pp. 301-323.

303. Kendall, P. Food Biotechnology: Boon or Threat? J. Nutr. Educ. 1997, 29, 112-115. [CrossRef] 
304. Reuter, T. Understanding Food System Resilience in Bali, Indonesia: A Moral Economy Approach. Cult. Agric. Food Environ. 2019, 41, 4-14. [CrossRef]

305. Arbit, N.; Ruby, M.B.; Sproesser, G.; Renner, B.; Schupp, H.; Rozin, P. Spheres of moral concern, moral engagement, and food choice in the USA and Germany. Food Qual. Prefer. 2017, 62, 38-45. [CrossRef]

306. Weiler, A.M.; Otero, G.; Wittman, H. Rock Stars and Bad Apples: Moral Economies of Alternative Food Networks and Precarious Farm Work Regimes. Antipode 2016, 48, 1140-1162. [CrossRef]

307. Benítez, B.; Nelson, E.; Romero Sarduy, M.I.; Ortíz Pérez, R.; Crespo Morales, A.; Casanova Rodríguez, C.; Campos Gómez, M.; Méndez Bordón, A.; Martínez Massip, A.; Hernández Beltrán, Y.; et al. Empowering Women and Building Sustainable Food Systems: A Case Study of Cuba's Local Agricultural Innovation Project. Front. Sustain. Food Syst. 2020, 4, 219. [CrossRef]

308. Cramer, S. Gaining Ground: An Exploration into the Lives of Missouri's Lesbian Farmers. J. Agric. Food Syst. Community Dev. 2020, 9, 1-16. [CrossRef]

309. Braun, J.; Beckie, M.; Caine, K. "Trust us, we feed this to our kids": Women and public trust in the Canadian agri-food system. Agric. Hum. Values 2020, 37, 495-507. [CrossRef]

310. Jaffe, J.; Gertler, M. Victual Vicissitudes: Consumer Deskilling and the (Gendered) Transformation of Food Systems. Agric. Hum. Values 2006, 23, 143-162. [CrossRef]

311. Slocum, R. Anti-racist Practice and the Work of Community Food Organizations. Antipode 2006, 38, 327-349. [CrossRef]

312. Kopainsky, B.; Frehner, A.; Müller, A. Sustainable and healthy diets: Synergies and trade-offs in Switzerland. Syst. Res. Behav. Sci. 2020, 37, 908-927. [CrossRef]

313. Broekema, R.; Tyszler, M.; van 't Veer, P.; Kok, F.J.; Martin, A.; Lluch, A.; Blonk, H.T.J. Future-proof and sustainable healthy diets based on current eating patterns in the Netherlands. Am. J. Clin. Nutr. 2020, 112, 1338-1347. [CrossRef]

314. Lonnie, M.; Johnstone, A.M. The public health rationale for promoting plant protein as an important part of a sustainable and healthy diet. Nutr. Bull. 2020, 45, 281-293. [CrossRef]

315. Peeters, A. Obesity and the future of food policies that promote healthy diets. Nat. Rev. Endocrinol. 2018, 14, 430-437. [CrossRef]

316. Stentiford, G.D.; Bateman, I.J.; Hinchliffe, S.J.; Bass, D.; Hartnell, R.; Santos, E.M.; Devlin, M.J.; Feist, S.W.; Taylor, N.G.H.; Verner-Jeffreys, D.W.; et al. Sustainable aquaculture through the One Health lens. Nat. Food 2020, 1, 468-474. [CrossRef]

317. Duru, M.; Le Bras, C. Crises environnementales et sanitaires: Des maladies de l'anthropocène qui appellent à refonder notre système alimentaire. Cah. Agric. 2020, 29, 34. [CrossRef]

318. Vartanova, M.L. Food Supply of the Population in the Conditions of the Global Response to the COVID-19 Pandemic. Rev. Inclusiones 2020, 7, 122-134.

319. Leone, L.A.; Fleischhacker, S.; Anderson-Steeves, B.; Harper, K.; Winkler, M.; Racine, E.; Baquero, B.; Gittelsohn, J. Healthy Food Retail during the COVID-19 Pandemic: Challenges and Future Directions. Int. J. Environ. Res. Public Health 2020, $17,7397$. [CrossRef]

320. Fleischhacker, S.E.; Woteki, C.E.; Coates, P.M.; Hubbard, V.S.; Flaherty, G.E.; Glickman, D.R.; Harkin, T.R.; Kessler, D.; Li, W.W.; Loscalzo, J.; et al. Strengthening national nutrition research: Rationale and options for a new coordinated federal research effort and authority. Am. J. Clin. Nutr. 2020, 112, 721-769. [CrossRef]

321. Rippin, H.L.; Wickramasinghe, K.; Halloran, A.; Whiting, S.; Williams, J.; Hetz, K.; Pinedo, A.; Breda, J.J. Disrupted food systems in the WHO European region-A threat or opportunity for healthy and sustainable food and nutrition? Food Secur. 2020, 12, 859-864. [CrossRef]

322. Pham, T.-T.-H.; Turner, S. 'If I want safe food I have to grow it myself': Patterns and motivations of urban agriculture in a small city in Vietnam's northern borderlands. Land Use Policy 2020, 96, 104681. [CrossRef]

323. Liu, R.; Gao, Z.; Nayga, R.M.; Snell, H.A.; Ma, H. Consumers' valuation for food traceability in China: Does trust matter? Food Policy 2019, 88, 101768. [CrossRef]

324. Ding, J.; Moustier, P.; Ma, X.; Huo, X.; Jia, X. Doing but not knowing: How apple farmers comply with standards in China. Agric. Hum. Values 2019, 36, 61-75. [CrossRef]

325. Flynn, K.; Villarreal, B.P.; Barranco, A.; Belc, N.; Björnsdóttir, B.; Fusco, V.; Rainieri, S.; Smaradóttir, S.E.; Smeu, I.; Teixeira, P.; et al. An introduction to current food safety needs. Trends Food Sci. Technol. 2019, 84, 1-3. [CrossRef]

326. Omotayo, O.P.; Omotayo, A.O.; Mwanza, M.; Babalola, O.O. Prevalence of Mycotoxins and Their Consequences on Human Health. Toxicol. Res. 2019, 35, 1-7. [CrossRef]

327. Turhan, S.; Rehber, E.; Erdal, B.; Vural, H. Toward an Integrated Safe and Sustainable Food system. Fresenius Environ. Bull. 2018, $27,3212-3217$.

328. Jennings, S.; Stentiford, G.D.; Leocadio, A.M.; Jeffery, K.R.; Metcalfe, J.D.; Katsiadaki, I.; Auchterlonie, N.A.; Mangi, S.C.; Pinnegar, J.K.; Ellis, T.; et al. Aquatic food security: Insights into challenges and solutions from an analysis of interactions between fisheries, aquaculture, food safety, human health, fish and human welfare, economy and environment. Fish Fish. 2016, 17, 893-938. [CrossRef]

329. Grace, D. Food Safety in Low and Middle Income Countries. Int. J. Environ. Res. Public Health 2015, 12, 10490-10507. [CrossRef]

330. Miewald, C.; Ostry, A.; Hodgson, S. Food safety at the small scale: The case of meat inspection regulations in British Columbia's rural and remote communities. J. Rural Stud. 2013, 32, 93-102. [CrossRef]

331. Wahlqvist, M.L.; Lee, M.-S. Regional food culture and development. Asia Pac. J. Clin. Nutr. 2007, 16, 2-7. [PubMed] 
332. Ray, A.; Ray, R.; Sreevidya, E.A. How Many Wild Edible Plants Do We Eat-Their Diversity, Use, and Implications for Sustainable Food System: An Exploratory Analysis in India. Front. Sustain. Food Syst. 2020, 4, 56. [CrossRef]

333. VanWinkle, T.N. "Savor the earth to save it!"-The pedagogy of sustainable pleasure and relational ecology in a place-based public culinary culture. Food Foodways 2017, 25, 40-57. [CrossRef]

334. Omotayo, A.O.; Aremu, A.O. Evaluation of Factors Influencing the Inclusion of Indigenous Plants for Food Security among Rural Households in the North West Province of South Africa. Sustainability 2020, 12, 9562. [CrossRef]

335. Guerrero Lara, L.; Pereira, L.; Ravera, F.; Jiménez-Aceituno, A. Flipping the Tortilla: Social-Ecological Innovations and Traditional Ecological Knowledge for More Sustainable Agri-Food Systems in Spain. Sustainability 2019, 11, 1222. [CrossRef]

336. Aiking, H.; de Boer, J. Protein and sustainability-The potential of insects. J. Insects Food Feed 2019, 5, 3-7. [CrossRef]

337. Lusk, J.L.; McCluskey, J. Understanding the impacts of food consumer choice and food policy outcomes. Appl. Econ. Perspect. Policy 2018, 40, 5-21. [CrossRef]

338. Saint-Eve, A.; Granda, P.; Legay, G.; Cuvelier, G.; Delarue, J. Consumer acceptance and sensory drivers of liking for high plant protein snacks. J. Sci. Food Agric. 2019, 99, 3983-3991. [CrossRef]

339. Haydon, P.; Tobi, R.; Bridge, G.; Gurung, I.; Scott, C. Peas Please: Making a pledge for more veg. Nutr. Bull. 2020, 45, 483-494. [CrossRef]

340. Mazzocchi, G.; Marino, D. Rome, a Policy without Politics: The Participatory Process for a Metropolitan Scale Food Policy. Int. J. Environ. Res. Public Health 2020, 17, 479. [CrossRef]

341. Doernberg, A.; Horn, P.; Zasada, I.; Piorr, A. Urban food policies in German city regions: An overview of key players and policy instruments. Food Policy 2019, 89, 101782. [CrossRef]

342. Filippini, R.; Mazzocchi, C.; Corsi, S. The contribution of Urban Food Policies toward food security in developing and developed countries: A network analysis approach. Sustain. Cities Soc. 2019, 47, 101506. [CrossRef]

343. Baldy, J. Framing a Sustainable Local Food System-How Smaller Cities in Southern Germany Are Facing a New Policy Issue. Sustainability 2019, 11, 1712. [CrossRef]

344. Moragues-Faus, A.; Sonnino, R. Re-assembling sustainable food cities: An exploration of translocal governance and its multiple agencies. Urban Stud. 2019, 56, 778-794. [CrossRef]

345. Sonnino, R.; Tegoni, C.L.S.; De Cunto, A. The challenge of systemic food change: Insights from cities. Cities 2019, 85, 110-116. [CrossRef]

346. Moschitz, H. Where is urban food policy in Switzerland? A frame analysis. Int. Plan. Stud. 2018, 23, 180-194. [CrossRef]

347. Dubbeling, M.; Santini, G.; Renting, H.; Taguchi, M.; Lançon, L.; Zuluaga, J.; de Paoli, L.; Rodriguez, A.; Andino, V. Assessing and Planning Sustainable City Region Food Systems: Insights from Two Latin American Cities. Sustainability 2017, 9, 1455. [CrossRef]

348. Lourival, I.; Rose, N. From Nar Nar Goon to Koo Wee Rup: Can Participatory Food Policy Making Processes Contribute to Healthier and Fairer Food Systems in the Australian Municipal Context? A Case Study from Cardinia Shire, Melbourne. J. Hunger Environ. Nutr. 2020, 1-35. [CrossRef]

349. Downs, S.M.; Payne, A.; Fanzo, J. The development and application of a sustainable diets framework for policy analysis: A case study of Nepal. Food Policy 2017, 70, 40-49. [CrossRef]

350. Roblin, L.; Truscott, R.; Boddy, M.R. The Development of a Provincial Food and Nutrition Strategy through Cross-Sector Collaboration. Can. J. Diet. Pract. Res. 2018, 79, 28-34. [CrossRef]

351. Crivits, M.; Prové, C.; Block, T.; Dessein, J. Four Perspectives of Sustainability Applied to the Local Food Strategy of Ghent (Belgium): Need for a Cycle of Democratic Participation? Sustainability 2016, 8, 55. [CrossRef]

352. Otiman, P.I.; Toderoiu, F.; Alexandri, C.; Florian, V.; Gavrilescu, C.; Ionel, I.; Sima, E.; Tudor, M.M. Sustainable Development Strategy for the Agri-food Sector and Rural Area-Horizon 2030. Procedia Econ. Financ. 2014, 8, 510-517. [CrossRef]

353. Battersby, J.; Watson, V. The planned 'city-region' in the New Urban Agenda: An appropriate framing for urban food security? Town Plan. Rev. 2019, 90, 497-518. [CrossRef]

354. Ahmed, S.; Downs, S.; Fanzo, J. Advancing an Integrative Framework to Evaluate Sustainability in National Dietary Guidelines. Front. Sustain. Food Syst. 2019, 3, 76. [CrossRef]

355. Lang, T.; Mason, P. Sustainable diet policy development: Implications of multi-criteria and other approaches, $2008-2017$. Proc. Nutr. Soc. 2018, 77, 331-346. [CrossRef]

356. Kimmons, J.; Jones, S.; McPeak, H.H.; Bowden, B. Developing and Implementing Health and Sustainability Guidelines for Institutional Food Service. Adv. Nutr. 2012, 3, 337-342. [CrossRef]

357. Jablonski, K.E.; Dillon, J.A.; Hale, J.W.; Jablonski, B.B.R.; Carolan, M.S. One Place Doesn't Fit All: Improving the Effectiveness of Sustainability Standards by Accounting for Place. Front. Sustain. Food Syst. 2020, 4, 557754. [CrossRef]

358. Sonnino, R.; Lozano Torres, C.; Schneider, S. Reflexive governance for food security: The example of school feeding in Brazil. J. Rural Stud. 2014, 36, 1-12. [CrossRef]

359. Agness, L.; Aichholz, K.; Gorle, R.; Quantz, G.; Russell, C.; Turkiewicz, A.; Louis, G. Redefining the Food Component of US Foreign Policy. In Proceedings of the Systems and Information Engineering Design Symposium (SIEDS), Charlottesville, VA, USA, 28 April 2017; IEEE: New York, NY, USA, 2017; pp. 84-88.

360. Atkey, K.; Elliott-Moyer, P.; Freimanis, M.; Raine, K.D. Stories of policy change: City of Hamilton's healthy food and beverage policy. Can. J. Public Health 2017, 108, e625-e629. [CrossRef] 
361. Lawrence, M.A.; Friel, S.; Wingrove, K.; James, S.W.; Candy, S. Formulating policy activities to promote healthy and sustainable diets. Public Health Nutr. 2015, 18, 2333-2340. [CrossRef] [PubMed]

362. Hayashi, F.; Takemi, Y. Why Is Creating a Healthy Food Environment So Crucial to Making Improvements in Diet-Related NCDs? J. Nutr. Sci. Vitaminol. 2015, 61, S36-S38. [CrossRef]

363. Lewis, S.A.; Fezzi, C.; Dacks, R.; Ferrini, S.; James, P.A.S.; Marino, L.; Golbuu, Y.; Oleson, K.L.L. Conservation policies informed by food system feedbacks can avoid unintended consequences. Nat. Food 2020, 1, 783-786. [CrossRef]

364. De Lind, L. Transforming Organic Agriculture into Industrial Organic Products: Reconsidering National Organic Standards. Hum. Organ. 2000, 59, 198-208. [CrossRef]

365. Cadillo-Benalcazar, J.J.; Renner, A.; Giampietro, M. A multiscale integrated analysis of the factors characterizing the sustainability of food systems in Europe. J. Environ. Manag. 2020, 271, 110944. [CrossRef] [PubMed]

366. Recanati, F.; Maughan, C.; Pedrotti, M.; Dembska, K.; Antonelli, M. Assessing the role of CAP for more sustainable and healthier food systems in Europe: A literature review. Sci. Total Environ. 2019, 653, 908-919. [CrossRef]

367. Bonanomi, S.; Colombelli, A.; Bucciarelli, B.; De Angelis, R.; Sala, A. Serving Local Fish in School Meals: The Nutritional Importance of Consuming Oily Fish. Sustainability 2019, 11, 3990. [CrossRef]

368. Lo, J.; Delwiche, A. The Good Food Purchasing Policy: A Tool to Intertwine Worker Justice with a Sustainable Food System. J. Agric. Food Syst. Community Dev. 2016, 184-194. [CrossRef]

369. Stead, S.M. Using systems thinking and open innovation to strengthen aquaculture policy for the United Nations Sustainable Development Goals. J. Fish Biol. 2019, 94, 837-844. [CrossRef]

370. Guarnaccia, P.; Zingale, S.; Scuderi, A.; Gori, E.; Santiglia, V.; Timpanaro, G. Proposal of a Bioregional Strategic Framework for a Sustainable Food System in Sicily. Agronomy 2020, 10, 1546. [CrossRef]

371. Melesse, M.B.; van den Berg, M.; Béné, C.; de Brauw, A.; Brouwer, I.D. Metrics to analyze and improve diets through food Systems in low and Middle Income Countries. Food Secur. 2020, 12, 1085-1105. [CrossRef]

372. Vermeulen, S.J.; Park, T.; Khoury, C.K.; Béné, C. Changing diets and the transformation of the global food system. Ann. N. Y. Acad. Sci. 2020, 1478, 3-17. [CrossRef]

373. Ma, L.; Bai, Z.; Ma, W.; Guo, M.; Jiang, R.; Liu, J.; Oenema, O.; Velthof, G.L.; Whitmore, A.P.; Crawford, J.; et al. Exploring Future Food Provision Scenarios for China. Environ. Sci. Technol. 2019, 53, 1385-1393. [CrossRef]

374. Chaudhary, A.; Gustafson, D.; Mathys, A. Multi-indicator sustainability assessment of global food systems. Nat. Commun. 2018, 9, 848. [CrossRef]

375. Temme, E.H.M.; Vellinga, R.E.; de Ruiter, H.; Kugelberg, S.; van de Kamp, M.; Milford, A.; Alessandrini, R.; Bartolini, F.; Sanz-Cobena, A.; Leip, A. Demand-Side Food Policies for Public and Planetary Health. Sustainability 2020, 12, 5924. [CrossRef]

376. Blay-Palmer, A.; Santini, G.; Dubbeling, M.; Renting, H.; Taguchi, M.; Giordano, T. Validating the City Region Food System Approach: Enacting Inclusive, Transformational City Region Food Systems. Sustainability 2018, 10, 1680. [CrossRef]

377. Weissman, E.; Potteiger, M. Collaboration and diverse stakeholder participation in food system planning: A case study from Central New York. Renew. Agric. Food Syst. 2020, 35, 115-119. [CrossRef]

378. Mangnus, A.C.; Vervoort, J.M.; McGreevy, S.R.; Ota, K.; Rupprecht, C.D.D.; Oga, M.; Kobayashi, M. New pathways for governing food system transformations: A pluralistic practice-based futures approach using visioning, back-casting, and serious gaming. Ecol. Soc. 2019, 24, art2. [CrossRef]

379. Calancie, L.; Cooksey-Stowers, K.; Palmer, A.; Frost, N.; Calhoun, H.; Piner, A.; Webb, K. Toward a Community Impact Assessment for Food Policy Councils: Identifying Potential Impact Domains. J. Agric. Food Syst. Community Dev. 2018, 8, 123-136. [CrossRef]

380. Haylock, K.; Connelly, S. Examining the Insider/Outsider Dimensions of Local Food System Planning: Cases from Dunedin and Christchurch New Zealand. Plan. Pract. Res. 2018, 33, 540-557. [CrossRef]

381. De Marco, M.; Chapman, L.; McGee, C.; Calancie, L.; Burnham, L.; Ammerman, A. Merging Opposing Viewpoints: Analysis of the Development of a Statewide Sustainable Local Food Advisory Council in a Traditional Agricultural State. J. Agric. Food Syst. Community Dev. 2017, 7, 197-210. [CrossRef]

382. Barling, D.; Lang, T.; Caraher, M. Joined-up food policy? The trials of governance, public policy and the food system. Soc. Policy Adm. 2002, 36, 556-574. [CrossRef]

383. Santo, R.; Moragues-Faus, A. Towards a trans-local food governance: Exploring the transformative capacity of food policy assemblages in the US and UK. Geoforum 2019, 98, 75-87. [CrossRef]

384. O'Brien, E.; Nisbett, N. Building a Sustainable Food City: A Collective Approach. IDS Bull. 2019, 50. [CrossRef]

385. Quest, J.; Shiel, C.; Watson, S. Transitioning towards a sustainable food city. Int. J. Sustain. High. Educ. 2019, $20,1258-1277$. [CrossRef]

386. Béné, C.; Fanzo, J.; Haddad, L.; Hawkes, C.; Caron, P.; Vermeulen, S.; Herrero, M.; Oosterveer, P. Five priorities to operationalize the EAT-Lancet Commission report. Nat. Food 2020, 1, 457-459. [CrossRef]

387. Wilkins, J.L. Eating Right Here: Moving from Consumer to Food Citizen. Agric. Human Values 2005, 22, 269-273. [CrossRef]

388. Allaby, M.; MacDonald, G.K.; Turner, S. Growing pains: Small-scale farmer responses to an urban rooftop farming and online marketplace enterprise in Montréal, Canada. Agric. Hum. Values 2020. [CrossRef]

389. Kahiluoto, H. Food systems for resilient futures. Food Secur. 2020, 12, 853-857. [CrossRef] 
390. Hennchen, B.; Pregernig, M. Organizing Joint Practices in Urban Food Initiatives-A Comparative Analysis of Gardening, Cooking and Eating Together. Sustainability 2020, 12, 4457. [CrossRef]

391. Dong, H.; Campbell, B.; Rabinowitz, A.N. Factors impacting producer marketing through community supported agriculture. PLOS ONE 2019, 14, e0219498. [CrossRef]

392. Beacham, J. Organising food differently: Towards a more-than-human ethics of care for the Anthropocene. Organization 2018, 25, 533-549. [CrossRef]

393. Balázs, B.; Pataki, G.; Lazányi, O. Prospects for the future: Community supported agriculture in Hungary. Futures 2016, 83, 100-111. [CrossRef]

394. Hvitsand, C. Community supported agriculture (CSA) as a transformational act-Distinct values and multiple motivations among farmers and consumers. Agroecol. Sustain. Food Syst. 2016, 40, 333-351. [CrossRef]

395. Balazs, B. Civil food networks-Stakeholders' experiences on the community supported agriculture in Hungary. Civ. Szle. 2013, 10, 107.

396. Porcher, N. Community Supported Agriculture in the French speaking part of Switzerland. Rev. Suisse D Agric. 2009, 41, 357-359.

397. Kolodinsky, J.M.; Pelch, L.L. Factors Influencing the Decision to Join a Community Supported Agriculture (CSA) Farm. J. Sustain. Agric. 1997, 10, 129-141. [CrossRef]

398. Grubb, M.; Vogl, C.R. Understanding Food Literacy in Urban Gardeners: A Case Study of the Twin Cities, Minnesota. Sustainability 2019, 11, 3617. [CrossRef]

399. Donovan, S. Growing Gardens Sustainability: Challenges and Opportunities Facing the Strategic Expansion of Anchorage, Alaska's Community Garden System. Case Stud. Environ. 2018, 2, 1-14. [CrossRef]

400. Mintz, G.; McManus, P. Seeds for Change? Attaining the benefits of community gardens through council policies in Sydney, Australia. Aust. Geogr. 2014, 45, 541-558. [CrossRef]

401. Lowitt, K.; Levkoe, C.Z.; Spring, A.; Turlo, C.; Williams, P.L.; Bird, S.; Sayers, C.D.; Simba, M. Empowering small-scale, community-based fisheries through a food systems framework. Mar. Policy 2020, 120, 104150. [CrossRef]

402. Simon, S.; Lesueur-Jannoyer, M.; Plénet, D.; Lauri, P.-É; Le Bellec, F. Methodology to design agroecological orchards: Learnings from on-station and on-farm experiences. Eur. J. Agron. 2017, 82, 320-330. [CrossRef]

403. Burgoa, J.M.F.D.; Rist, S.; Jacobi, J.; Wambugu, G.; Ngutu, M.; Augstburger, H.; Mwangi, V.; Zonta, A.L.; Otieno, S.; Kiteme, B.P.; et al. Mapping Food Systems: A Participatory Research Tool Tested in Kenya and Bolivia. Mt. Res. Dev. 2019, 39. [CrossRef]

404. Sowerwine, J.; Sarna-Wojcicki, D.; Mucioki, M.; Hillman, L.; Lake, F.; Friedman, E. Enhancing Food Sovereignty: A Five-year Collaborative Tribal-University Research and Extension Project in California and Oregon. J. Agric. Food Syst. Community Dev. 2019, 167-190. [CrossRef]

405. Guzmán, G.I.; López, D.; Román, L.; Alonso, A.M. Participatory Action Research in Agroecology: Building Local Organic Food Networks in Spain. J. Sustain. Agric. 2012, 37, 120904081413002. [CrossRef]

406. Li, J.; Lammerts van Bueren, E.T.; Leeuwis, C.; Jiggins, J. Expressing the public value of plant genetic resources by organising novel relationships: The contribution of selected participatory plant breeding and market-based arrangements. J. Rural Stud. 2014, 36, 182-196. [CrossRef]

407. Kaufmann, S.; Hruschka, N.; Vogl, C.R. Bridging the Literature Gap: A Framework for Assessing Actor Participation in Participatory Guarantee Systems (PGS). Sustainability 2020, 12, 8100. [CrossRef]

408. Rover, O.; de Gennaro, B.; Roselli, L. Social Innovation and Sustainable Rural Development: The Case of a Brazilian Agroecology Network. Sustainability 2016, 9, 3. [CrossRef]

409. Hebinck, A.; Page, D. Processes of Participation in the Development of Urban Food Strategies: A Comparative Assessment of Exeter and Eindhoven. Sustainability 2017, 9, 931. [CrossRef]

410. Brown, S.; Getz, C. Privatizing farm worker justice: Regulating labor through voluntary certification and labeling. Geoforum 2008, 39, 1184-1196. [CrossRef]

411. De Bernardi, P.; Bertello, A.; Venuti, F.; Foscolo, E. How to avoid the tragedy of alternative food networks (AFNs)? The impact of social capital and transparency on AFN performance. Br. Food J. 2020, 122, 2171-2186. [CrossRef]

412. Kos, D.; Kloppenburg, S. Digital technologies, hyper-transparency and smallholder farmer inclusion in global value chains. Curr. Opin. Environ. Sustain. 2019, 41, 56-63. [CrossRef]

413. Ajates, R. Agricultural cooperatives remaining competitive in a globalised food system: At what cost to members, the cooperative movement and food sustainability? Organization 2020, 27, 337-355. [CrossRef]

414. Ajates, R. An integrated conceptual framework for the study of agricultural cooperatives: From repolitisation to cooperative sustainability. J. Rural Stud. 2020, 78, 467-479. [CrossRef]

415. Akinola, R.; Pereira, L.M.; Mabhaudhi, T.; de Bruin, F.-M.; Rusch, L. A Review of Indigenous Food Crops in Africa and the Implications for more Sustainable and Healthy Food Systems. Sustainability 2020, 12, 3493. [CrossRef]

416. Al Sidawi, R.; Urushadze, T.; Ploeger, A. Changes in Dairy Products Value Chain in Georgia. Sustainability 2020, $12,5894$. [CrossRef] 
417. Alae-Carew, C.; Nicoleau, S.; Bird, F.A.; Hawkins, P.; Tuomisto, H.L.; Haines, A.; Dangour, A.D.; Scheelbeek, P.F.D. The impact of environmental changes on the yield and nutritional quality of fruits, nuts and seeds: A systematic review. Environ. Res. Lett. 2020, 15, 023002. [CrossRef]

418. Albert, J.; Bogard, J.; Siota, F.; McCarter, J.; Diatalau, S.; Maelaua, J.; Brewer, T.; Andrew, N. Malnutrition in rural Solomon Islands: An analysis of the problem and its drivers. Matern. Child Nutr. 2020, 16. [CrossRef]

419. Al-Jawaldeh, A.; Almamary, S.; Mahmoud, L.; Nasreddine, L. Leveraging the Food System in the Eastern Mediterranean Region for Better Health and Nutrition: A Case Study from Oman. Int. J. Environ. Res. Public Health 2020, 17, 7250. [CrossRef]

420. Amicarelli, V.; Bux, C. Food waste measurement toward a fair, healthy and environmental-friendly food system: A critical review. Br. Food J. 2020. [CrossRef]

421. Amiri, A.; Mehrjerdi, Y.Z.; Jalalimanesh, A.; Sadegheih, A. Investigating the sustainability of a food system by system dynamics approach. Int. J. Intell. Eng. Inform. 2020, 8, 198. [CrossRef]

422. Amiri, A.; Mehrjerdi, Y.Z.; Jalalimanesh, A.; Sadegheih, A. Food system sustainability investigation using system dynamics approach. J. Clean. Prod. 2020, 277, 124040. [CrossRef]

423. Andress, L.; Byker Shanks, C.; Hardison-Moody, A.; Prewitt, T.E.; Kinder, P.; Haynes-Maslow, L. The Curated Food System: A Limiting Aspirational Vision of What Constitutes “Good" Food. Int. J. Environ. Res. Public Health 2020, 17, 6157. [CrossRef]

424. April-Lalonde, G.; Latorre, S.; Paredes, M.; Hurtado, M.F.; Muñoz, F.; Deaconu, A.; Cole, D.C.; Batal, M. Characteristics and Motivations of Consumers of Direct Purchasing Channels and the Perceived Barriers to Alternative Food Purchase: A Cross-Sectional Study in the Ecuadorian Andes. Sustainability 2020, 12, 6923. [CrossRef]

425. Aschemann-Witzel, J.; Gantriis, R.F.; Fraga, P.; Perez-Cueto, F.J.A. Plant-based food and protein trend from a business perspective: Markets, consumers, and the challenges and opportunities in the future. Crit. Rev. Food Sci. Nutr. 2020, 61, 1-10. [CrossRef]

426. Augstburger, H.; Rist, S. Assessing the capacity of three Bolivian food systems to provide farm-based agroecosystem services. J. Land Use Sci. 2020, 15, 142-171. [CrossRef]

427. Augustin, M.A.; Sanguansri, L.; Fox, E.M.; Cobiac, L.; Cole, M.B. Recovery of wasted fruit and vegetables for improving sustainable diets. Trends Food Sci. Technol. 2020, 95, 75-85. [CrossRef]

428. Baiguzhinova, A.; Omarbakiyev, L.; Yeshpanova, D.; Bazarbayev, A.; Abdrakhmanova, G.; Karshalova, A. Mechanism for sustainable development of economic potential of food industry. Entrep. Sustain. Issues 2020, 8, 825-840. [CrossRef]

429. Bajželj, B.; Quested, T.E.; Röös, E.; Swannell, R.P.J. The role of reducing food waste for resilient food systems. Ecosyst. Serv. 2020, 45, 101140. [CrossRef]

430. Bartelmeß, T.; Godemann, J. Corporate Perspectives on Responsibility and Sustainability in the Food System: A (Food) Communicative-Constructivist Viewpoint. Sustainability 2020, 12, 2024. [CrossRef]

431. Bas-Bellver, C.; Barrera, C.; Betoret, N.; Seguí, L. Turning Agri-Food Cooperative Vegetable Residues into Functional Powdered Ingredients for the Food Industry. Sustainability 2020, 12, 1284. [CrossRef]

432. Basso, B.; Antle, J. Digital agriculture to design sustainable agricultural systems. Nat. Sustain. 2020, 3, 254-256. [CrossRef]

433. Bazaluk, O.; Yatsenko, O.; Zakharchuk, O.; Ovcharenko, A.; Khrystenko, O.; Nitsenko, V. Dynamic Development of the Global Organic Food Market and Opportunities for Ukraine. Sustainability 2020, 12, 6963. [CrossRef]

434. Beingessner, N.; Fletcher, A.J. "Going local”: Farmers' perspectives on local food systems in rural Canada. Agric. Hum. Values 2020, 37, 129-145. [CrossRef]

435. Bencze, S.; Makádi, M.; Aranyos, T.J.; Földi, M.; Hertelendy, P.; Mikó, P.; Bosi, S.; Negri, L.; Drexler, D. Re-Introduction of Ancient Wheat Cultivars into Organic Agriculture-Emmer and Einkorn Cultivation Experiences under Marginal Conditions. Sustainability 2020, 12, 1584. [CrossRef]

436. Béné, C.; Fanzo, J.; Prager, S.D.; Achicanoy, H.A.; Mapes, B.R.; Alvarez Toro, P.; Bonilla Cedrez, C. Global drivers of food system (un)sustainability: A multi-country correlation analysis. PLoS ONE 2020, 15, e0231071. [CrossRef]

437. Bentham, J.; Singh, G.M.; Danaei, G.; Green, R.; Lin, J.K.; Stevens, G.A.; Farzadfar, F.; Bennett, J.E.; Di Cesare, M.; Dangour, A.D.; et al. Multidimensional characterization of global food supply from 1961 to 2013. Nat. Food 2020, 1, 70-75. [CrossRef]

438. Berti, G. Sustainable Agri-Food Economies: Re-Territorialising Farming Practices, Markets, Supply Chains, and Policies. Agriculture 2020, 10, 64. [CrossRef]

439. Bloom, J.; Lelekacs, J.; Hofing, G.; Stout, R.; Marshall, M.; Davis, K. Integrating Food Systems and Local Food in Family and Consumer Sciences: Perspectives from the Pilot Extension Master Food Volunteer Program. J. Agric. Food Syst. Community Dev. 2020, 1-24. [CrossRef]

440. Bocken, N.; Morales, L.S.; Lehner, M. Sufficiency Business Strategies in the Food Industry-The Case of Oatly. Sustainability 2020, 12, 824. [CrossRef]

441. Boylan, S.M.; Thow, A.-M.; Tyedmers, E.K.; Malik, A.; Salem, J.; Alders, R.; Raubenheimer, D.; Lenzen, M. Using Input-Output Analysis to Measure Healthy, Sustainable Food Systems. Front. Sustain. Food Syst. 2020, 4, 93. [CrossRef]

442. Brandão, E.A.F.; da Santos, T.R.; Rist, S. Family Farmers' Perceptions of the Impact of Public Policies on the Food System: Findings From Brazil's Semi-Arid Region. Front. Sustain. Food Syst. 2020, 4, 158. [CrossRef]

443. Bryceson, K.P.; Ross, A. Agrifood Chains as Complex Systems and the Role of Informality in Their Sustainability in Small Scale Societies. Sustainability 2020, 12, 6535. [CrossRef] 
444. Bumbac, R.; Bobe, M.; Procopie, R.; Pamfilie, R.; Giușcă, S.; Enache, C. How Zoomers' Eating Habits Should be Considered in Shaping the Food System for 2030-A Case Study on the Young Generation from Romania. Sustainability 2020, 12, 7390. [CrossRef]

445. Cadel, E.; Massari, S.; Antonelli, M. Food, Education and Research: Towards a Sustainable Future. Biolaw J. Riv. Biodiritto 2020, 117-125.

446. Carino, S.; McCartan, J.; Barbour, L. The Emerging Landscape for Sustainable Food System Education: Mapping Current Higher Education Opportunities for Australia's Future Food and Nutrition Workforce. J. Hunger Environ. Nutr. 2020, 15, 273-294. [CrossRef]

447. Carlsson, L.; Callaghan, E.; Broman, G. Assessing Community Contributions to Sustainable Food Systems: Dietitians Leverage Practice, Process and Paradigms. Syst. Pract. Action Res. 2020. [CrossRef]

448. Chapman, A.M.; Perkins, H.A. Malign and benign neglect: A local food system and the myth of sustainable redevelopment in Appalachia Ohio. Agric. Hum. Values 2020, 37, 113-127. [CrossRef]

449. Clay, N.; Garnett, T.; Lorimer, J. Dairy intensification: Drivers, impacts and alternatives. Ambio 2020, 49, 35-48. [CrossRef]

450. Coad, J.; Pedley, K. Nutrition in New Zealand: Can the Past Offer Lessons for the Present and Guidance for the Future? Nutrients 2020, 12, 3433. [CrossRef]

451. Colby, A. 'It connects me to the earth': Marginalized environmentalism and a resistance to capitalist logic among subsistence food producers in Chicago. Environ. Sociol. 2020, 6, 82-94. [CrossRef]

452. Conner, D. Exploring Resource Management for Sustainable Food Businesses: Three Vermont Case Studies. J. Agric. Food Syst. Community Dev. 2020, 9, 99-107. [CrossRef]

453. Culliford, A.; Bradbury, J. A cross-sectional survey of the readiness of consumers to adopt an environmentally sustainable diet. Nutr. J. 2020, 19, 138. [CrossRef]

454. Dalmoro, M.; Matos, C.A.; Barcellos, M.D. Anticonsumption beyond consumers: The role of small organic producers in environmentally oriented anticonsumption. Psychol. Mark. 2020, 37, 291-307. [CrossRef]

455. Davies, W.J.; Ward, S.E.; Wilson, A. Can crop science really help us to produce more better-quality food while reducing the world-wide environmental footprint of agriculture? Front. Agric. Sci. Eng. 2020, 7, 28. [CrossRef]

456. De Olde, E.M.; van der Linden, A.; olde Bolhaar, L.D.; de Boer, I.J.M. Sustainability challenges and innovations in the Dutch egg sector. J. Clean. Prod. 2020, 258, 120974. [CrossRef]

457. De Sousa, K.; Solberg, S.Ø. Conservation Gaps in Traditional Vegetables Native to Europe and Fennoscandia. Agriculture 2020, 10, 340. [CrossRef]

458. Derunova, E.; Kireeva, N.; Pruschak, O. The Level and Quality of Inclusive Growth Agri-Food system in Modern Conditions. Sci. Pap. Ser. Manag. Econ. Eng. Agric. Rural Dev. 2020, 20, 193-206.

459. Derunova, E.; Kireeva, N.; Pruschak, O. The Role of State Support in Ensuring the Incusive Development of the Agri-Food system. Sci. Pap. Manag. Econ. Eng. Agric. Rural Dev. 2020, 20, 161-171.

460. Di Vaio, A.; Boccia, F.; Landriani, L.; Palladino, R. Artificial Intelligence in the Agri-Food System: Rethinking Sustainable Business Models in the COVID-19 Scenario. Sustainability 2020, 12, 4851. [CrossRef]

461. Dijkshoorn-Dekker, M.; Linderhof, V.; Mattijssen, T.J.M.; Polman, N. Food Secure Metropolitan Areas: The Transition Support System Approach. Sustainability 2020, 12, 5376. [CrossRef]

462. Dillon, J.A.; lan Rotz, C.A.; Karsten, H.D. Management characteristics of Northeast US grass-fed beef production systems. Appl. Anim. Sci. 2020, 36, 715-730. [CrossRef]

463. Dorninger, C.; Abson, D.J.; Apetrei, C.I.; Derwort, P.; Ives, C.D.; Klaniecki, K.; Lam, D.P.M.; Langsenlehner, M.; Riechers, M.; Spittler, N.; et al. Leverage points for sustainability transformation: A review on interventions in food and energy systems. Ecol. Econ. 2020, 171, 106570. [CrossRef]

464. Downs, S.M.; Ahmed, S.; Fanzo, J.; Herforth, A. Food Environment Typology: Advancing an Expanded Definition, Framework, and Methodological Approach for Improved Characterization of Wild, Cultivated, and Built Food Environments toward Sustainable Diets. Foods 2020, 9, 532. [CrossRef]

465. Ebel, R. Are Small Farms Sustainable by Nature?-Review of an Ongoing Misunderstanding in Agroecology. Challenges Sustain. 2020, 8. [CrossRef]

466. Eriksson, M.; Malefors, C.; Bergström, P.; Eriksson, E.; Persson Osowski, C. Quantities and Quantification Methodologies of Food Waste in Swedish Hospitals. Sustainability 2020, 12, 3116. [CrossRef]

467. Fardet, A.; Rock, E. How to protect both health and food system sustainability? A holistic 'global health'-based approach via the 3 V rule proposal. Public Health Nutr. 2020, 23, 3028-3044. [CrossRef]

468. Fardet, A.; Rock, E. Ultra-Processed Foods and Food System Sustainability: What Are the Links? Sustainability 2020, 12, 6280. [CrossRef]

469. Farmery, A.K.; van Putten, I.E.; Phillipov, M.; McIlgorm, A. Are media messages to consume more under-utilized seafood species reliable? Fish Fish. 2020, 21, 844-855. [CrossRef]

470. Feijoo, G.; Moreira, M.T. Fostering environmental awareness towards responsible food consumption and reduced food waste in chemical engineering students. Educ. Chem. Eng. 2020, 33, 27-35. [CrossRef]

471. Fesenfeld, L.P.; Wicki, M.; Sun, Y.; Bernauer, T. Policy packaging can make food system transformation feasible. Nat. Food 2020, 1, 173-182. [CrossRef] 
472. Fischer, C.; Miglietta, P.P. The Links between Human Diets and Health and Climate Outcomes in the World's Macro-Regions during the Last 50 Years. Int. J. Environ. Res. Public Health 2020, 17, 1219. [CrossRef] [PubMed]

473. Fogarassy, C.; Nagy-Pércsi, K.; Ajibade, S.; Gyuricza, C.; Ymeri, P. Relations between Circular Economic "Principles" and Organic Food Purchasing Behavior in Hungary. Agronomy 2020, 10, 616. [CrossRef]

474. Formoso, G.; Pipino, C.; Baldassarre, M.P.A.; Del Boccio, P.; Zucchelli, M.; D’Alessandro, N.; Tonucci, L.; Cichelli, A.; Pandolfi, A.; Di Pietro, N. An Italian Innovative Small-Scale Approach to Promote the Conscious Consumption of Healthy Food. Appl. Sci. 2020, 10, 5678. [CrossRef]

475. Rodrigues Fortes, A.; Ferreira, V.; Barbosa Simões, E.; Baptista, I.; Grando, S.; Sequeira, E. Food Systems and Food Security: The Role of Small Farms and Small Food Businesses in Santiago Island, Cabo Verde. Agriculture 2020, 10, 216. [CrossRef]

476. Freed, S.; Barman, B.; Dubois, M.; Flor, R.J.; Funge-Smith, S.; Gregory, R.; Hadi, B.A.R.; Halwart, M.; Haque, M.; Jagadish, S.V.K.; et al. Maintaining Diversity of Integrated Rice and Fish Production Confers Adaptability of Food Systems to Global Change. Front. Sustain. Food Syst. 2020, 4, 207. [CrossRef]

477. Frison, E.; Clément, C. The potential of diversified agroecological systems to deliver healthy outcomes: Making the link between agriculture, food systems \& health. Food Policy 2020, 96, 101851. [CrossRef]

478. Gaitán-Cremaschi, D.; Klerkx, L.; Duncan, J.; Trienekens, J.H.; Huenchuleo, C.; Dogliotti, S.; Contesse, M.E.; Benitez-Altuna, F.J.; Rossing, W.A.H. Sustainability transition pathways through ecological intensification: An assessment of vegetable food systems in Chile. Int. J. Agric. Sustain. 2020, 18, 131-150. [CrossRef]

479. García-Oliveira, P.; Fraga-Corral, M.; Pereira, A.G.; Prieto, M.A.; Simal-Gandara, J. Solutions for the sustainability of the food production and consumption system. Crit. Rev. Food Sci. Nutr. 2020, 61, 1-17. [CrossRef]

480. Navarro Gausa, M.; Pericu, S.; Canessa, N.; Tucci, G. Creative Food Cycles: A Cultural Approach to the Food Life-Cycles in Cities. Sustainability 2020, 12, 6487. [CrossRef]

481. Gerritsen, S.; Harré, S.; Rees, D.; Renker-Darby, A.; Bartos, A.E.; Waterlander, W.E.; Swinburn, B. Community Group Model Building as a Method for Engaging Participants and Mobilising Action in Public Health. Int. J. Environ. Res. Public Health 2020, 17, 3457. [CrossRef]

482. Gésan-Guiziou, G.; Alaphilippe, A.; Aubin, J.; Bockstaller, C.; Boutrou, R.; Buche, P.; Collet, C.; Girard, A.; Martinet, V.; Membré, J.-M.; et al. Diversity and potentiality of multi-criteria decision analysis methods for agri-food research. Agron. Sustain. Dev. 2020, 40, 44. [CrossRef]

483. Ginani, V.C.; Araújo, W.M.C.; Zandonadi, R.P.; Botelho, R.B.A. Identifier of Regional Food Presence (IRFP): A New Perspective to Evaluate Sustainable Menus. Sustainability 2020, 12, 3992. [CrossRef]

484. Girard, M. Le développement des agricultures durables dans la région andine de Cusco: Quelle proximité socio-économique entre conseillers agricoles, producteurs et consommateurs? Développement Durable Territ. 2020. [CrossRef]

485. Granheim, S.I.; Opheim, E.; Terragni, L.; Torheim, L.E.; Thurston, M. Mapping the digital food environment: A scoping review protocol. BMJ Open 2020, 10, e036241. [CrossRef]

486. Guareschi, M.; Maccari, M.; Sciurano, J.P.; Arfini, F.; Pronti, A. A Methodological Approach to Upscale Toward an Agroecology System in EU-LAFSs: The Case of the Parma Bio-District. Sustainability 2020, 12, 5398. [CrossRef]

487. Gugerell, C.; Penker, M. Change Agents' Perspectives on Spatial-Relational Proximities and Urban Food Niches. Sustainability 2020, 12, 2333. [CrossRef]

488. Guillaumie, L.; Boiral, O.; Baghdadli, A.; Mercille, G. Integrating sustainable nutrition into health-related institutions: A systematic review of the literature. Can. J. Public Health 2020, 111, 845-861. [CrossRef]

489. Hanigan, M.D.; Daley, V.L. Use of Mechanistic Nutrition Models to Identify Sustainable Food Animal Production. Annu. Rev. Anim. Biosci. 2020, 8, 355-376. [CrossRef]

490. Hatanaka, M. Beyond consuming ethically? Food citizens, governance, and sustainability. J. Rural Stud. 2020, 77, 55-62. [CrossRef]

491. Helenius, J.; Hagolani-Albov, S.E.; Koppelmäki, K. Co-creating Agroecological Symbioses (AES) for Sustainable Food System Networks. Front. Sustain. Food Syst. 2020, 4, 588715. [CrossRef]

492. Hendrickson, M.K.; Massengale, S.H.; Cantrell, R. “No money exchanged hands, no bartering took place. But it's still local produce": Understanding local food systems in rural areas in the U.S. Heartland. J. Rural Stud. 2020, 78, 480-490. [CrossRef]

493. Herrero, M.; Thornton, P.K.; Mason-D'Croz, D.; Palmer, J.; Benton, T.G.; Bodirsky, B.L.; Bogard, J.R.; Hall, A.; Lee, B.; Nyborg, K.; et al. Innovation can accelerate the transition towards a sustainable food system. Nat. Food 2020, 1, $266-272$. [CrossRef]

494. Heslin, A.; Puma, M.J.; Marchand, P.; Carr, J.A.; Dell'Angelo, J.; D’Odorico, P.; Gephart, J.A.; Kummu, M.; Porkka, M.; Rulli, M.C.; et al. Simulating the Cascading Effects of an Extreme Agricultural Production Shock: Global Implications of a Contemporary US Dust Bowl Event. Front. Sustain. Food Syst. 2020, 4, 26. [CrossRef]

495. Hilborn, R.; Amoroso, R.O.; Anderson, C.M.; Baum, J.K.; Branch, T.A.; Costello, C.; de Moor, C.L.; Faraj, A.; Hively, D.; Jensen, O.P.; et al. Effective fisheries management instrumental in improving fish stock status. Proc. Natl. Acad. Sci. USA 2020, 117, 2218-2224. [CrossRef]

496. Huan-Niemi, E.; Kaljonen, M.; Knuuttila, M.; Niemi, J.; Saarinen, M. The impacts of dietary change in Finland: Food system approach. Agric. Food Sci. 2020, 29, 372-382. [CrossRef] 
497. Jacob, M.C.M.; Feitosa, I.S.; de Araujo, J.Y.M.; Batista, N.A.D.N.; Silva, T.L.L.D.; Motta, V.W.D.L.; de Albuquerque, U.P. Rapid Ethnonutrition Assessment Method Is Useful to Prototype Dietary Assessments with a Focus on Local Biodiverse Food Plants. Ecol. Food Nutr. 2020, 60, 334-350. [CrossRef]

498. Jehlička, P.; Grīvin̦š, M.; Visser, O.; Balázs, B. Thinking food like an East European: A critical reflection on the framing of food systems. J. Rural Stud. 2020, 76, 286-295. [CrossRef]

499. King, H.B. Whose work is real work? A triple labor framework for sustainable development initiatives. Econ. Anthropol. 2020, 7 , 215-227. [CrossRef]

500. Klerkx, L.; Rose, D. Dealing with the game-changing technologies of Agriculture 4.0: How do we manage diversity and responsibility in food system transition pathways? Glob. Food Sec. 2020, 24, 100347. [CrossRef]

501. Ku, H.B.; Kan, K. Social work and sustainable rural development: The practice of social economy in China. Int. J. Soc. Welf. 2020, 29, 355. [CrossRef]

502. Kuo, W.; Kim, S.; Lachapelle, P. Incorporating community culture in teaching food innovation: Ideation, prototyping, and storytelling. J. Food Sci. Educ. 2020, 19, 292-307. [CrossRef]

503. Kusch-Brandt, S. Towards More Sustainable Food Systems-14 Lessons Learned. Int. J. Environ. Res. Public Health 2020, 17, 4005. [CrossRef]

504. Lajoie-O'Malley, A.; Bronson, K.; van der Burg, S.; Klerkx, L. The future(s) of digital agriculture and sustainable food systems: An analysis of high-level policy documents. Ecosyst. Serv. 2020, 45, 101183. [CrossRef]

505. Lee, J.M.; Contento, I.; Gray, H.L. Change in Food Consumption and Food Choice Determinants among East Asian International Students in New York. J. Hunger Environ. Nutr. 2020, 15, 418-441. [CrossRef]

506. Lopez, V.; Teufel, J.; Gensch, C.-O. How a Transformation towards Sustainable Community Catering Can Succeed. Sustainability 2019, 12, 101. [CrossRef]

507. Mapiye, O.; Chikwanha, O.C.; Makombe, G.; Dzama, K.; Mapiye, C. Livelihood, Food and Nutrition Security in Southern Africa: What Role Do Indigenous Cattle Genetic Resources Play? Diversity 2020, 12, 74. [CrossRef]

508. Martindale, W.; Duong, L.; Hollands, T.Æ.; Swainson, M. Testing the data platforms required for the 21st century food system using an industry ecosystem approach. Sci. Total Environ. 2020, 724, 137871. [CrossRef]

509. Martindale, W.; Swainson, M.; Choudhary, S. The Impact of Resource and Nutritional Resilience on the Global Food Supply System. Sustainability 2020, 12, 751. [CrossRef]

510. Martinelli, S.S.; Cavalli, S.B.; Fabri, R.K.; Veiros, M.B.; Reis, A.B.C.; Amparo-Santos, L. Strategies for the promotion of healthy, adequate and sustainable food in Brazil in times of Covid-19. Rev. Nutr. 2020, 33, e200181. [CrossRef]

511. Matacena, R.; Corvo, P. Practices of Food Sovereignty in Italy and England: Short Food Supply Chains and the Promise of De-Commodification. Sociol. Rural. 2020, 60, 414-437. [CrossRef]

512. Mayton, H.; Beal, T.; Rubin, J.; Sanchez, A.; Heller, M.; Hoey, L.; de Haan, S.; Duong, T.T.; Huynh, T.; Burra, D.D.; et al. Conceptualizing sustainable diets in Vietnam: Minimum metrics and potential leverage points. Food Policy 2020, $91,101836$. [CrossRef]

513. McClements, D.J. Future foods: Is it possible to design a healthier and more sustainable food supply? Nutr. Bull. 2020, 45, 341-354. [CrossRef]

514. Mehta, K.; Rohrlach, H.; Woodman, R.; Coveney, J.; Ward, P.; Booth, S. A critical food system program in South Australia and the effects on consumer knowledge and attitudes. Health Promot. J. Aust. 2020. [CrossRef]

515. Meyer, M.A. The role of resilience in food system studies in low- and middle-income countries. Glob. Food Sec. 2020, $24,100356$. [CrossRef]

516. Michell, K.A.; Isweiri, H.; Newman, S.E.; Bunning, M.; Bellows, L.L.; Dinges, M.M.; Grabos, L.E.; Rao, S.; Foster, M.T.; Heuberger, A.L.; et al. Microgreens: Consumer sensory perception and acceptance of an emerging functional food crop. J. Food Sci. 2020, 85, 926-935. [CrossRef]

517. Millet, M.; Keast, V.; Gonano, S.; Casabianca, F. Product qualification as a means of identifying sustainability pathways for place-based agri-food systems: The Case of the GI Corsican Grapefruit (France). Sustainability 2020, 12, 7148. [CrossRef]

518. Moberg, E.; Karlsson Potter, H.; Wood, A.; Hansson, P.-A.; Röös, E. Benchmarking the Swedish Diet Relative to Global and National Environmental Targets-Identification of Indicator Limitations and Data Gaps. Sustainability 2020, $12,1407$. [CrossRef]

519. Morel, K.; Revoyron, E.; San Cristobal, M.; Baret, P.V. Innovating within or outside dominant food systems? Different challenges for contrasting crop diversification strategies in Europe. PLoS ONE 2020, 15, e0229910. [CrossRef]

520. Mullender, S.M.; Sandor, M.; Pisanelli, A.; Kozyra, J.; Borek, R.; Ghaley, B.B.; Gliga, A.; von Oppenkowski, M.; Roesler, T.; Salkanovic, E.; et al. A delphi-style approach for developing an integrated food/non-food system sustainability assessment tool. Environ. Impact Assess. Rev. 2020, 84, 106415. [CrossRef]

521. Naja, F.; Hwalla, N.; El Zouhbi, A.; Abbas, N.; Chamieh, M.C.; Nasreddine, L.; Jomaa, L. Changes in Environmental Footprints Associated with Dietary Intake of Lebanese Adolescents between the Years 1997 and 2009. Sustainability 2020, 12, 4519. [CrossRef]

522. Niederle, P.; Schubert, M.N. HOW does veganism contribute to shape sustainable food systems? Practices, meanings and identities of vegan restaurants in Porto Alegre, Brazil. J. Rural Stud. 2020, 78, 304-313. [CrossRef]

523. Nosratabadi, S.; Khazami, N.; Abdallah, M.B.; Lackner, Z.; Shabad, Z.B.; Mosavi, A.; Mako, C. Social Capital Contributions to Food Security: A Comprehensive Literature Review. Foods 2020, 9, 1650. [CrossRef] [PubMed] 
524. Nowack, W.; Hoffmann, H. 'We are fed up'-Encountering the complex German call for sustainable, small-scale agriculture. J. Peasant Stud. 2020, 47, 420-429. [CrossRef]

525. O'Kane, G.M.; Pamphilon, B. 'My Lifestyle Kind of Locks Me into Supermarket Shopping': Narratives of Reflexivity and Routines from Supermarket Shoppers in Australia. J. Hunger Environ. Nutr. 2020, 15, 372-387. [CrossRef]

526. Oo, K.; Stephenson, T.; Hege, A.; Brewer, D.; Gamboa, L.; Hildesheim, L.; Serra, L.; Houlihan, J.; Koempel, A. Addressing Childhood Hunger during the Summer Months: Using Gleaned Produce for Snacks and Interactive Nutrition Education on Food Systems and Healthy Eating. J. Hunger Environ. Nutr. 2020, 15, 527-539. [CrossRef]

527. Palmioli, L.; Grando, S.; Di Iacovo, F.; Fastelli, L.; Galli, F.; Prosperi, P.; Rovai, M.; Brunori, G. Small farms' strategies between selfprovision and socio-economic integration: Effects on food system capacity to provide food and nutrition security. Local Environ. 2020, 25, 43-56. [CrossRef]

528. Park, D.; Park, Y.K.; Park, C.Y.; Choi, M.-K.; Shin, M.-J. Development of a Comprehensive Food Literacy Measurement Tool Integrating the Food System and Sustainability. Nutrients 2020, 12, 3300. [CrossRef]

529. Pereira, L.M.; Drimie, S.; Maciejewski, K.; Tonissen, P.B.; Biggs, R. (Oonsie) Food system transformation: Integrating a politicaleconomy and social-ecological approach to regime shifts. Int. J. Environ. Res. Public Health 2020, 17, 1313. [CrossRef]

530. Pilipuk, A.V. Conditions and factors of efficient integration of AIC of Belarus into the global food trading system. Proc. Natl. Acad. Sci. Belarus. Agrar. Ser. 2020, 58, 415-431. [CrossRef]

531. Przelomska, N.A.S.; Armstrong, C.G.; Kistler, L. Ancient plant DNA as a window into the cultural heritage and biodiversity of our food system. Front. Ecol. Evol. 2020, 8, 74. [CrossRef]

532. Raheem, D. Digitalisation in a local food system: Emphasis on Finnish Lapland. Open Agric. 2020, 5, 496-508. [CrossRef]

533. Reay, D.S.; Warnatzsch, E.A.; Craig, E.; Dawson, L.; George, S.; Norman, R.; Ritchie, P. From farm to fork: Growing a scottish food system that doesn't cost the planet. Front. Sustain. Food Syst. 2020, 4, 72. [CrossRef]

534. Reinhardt, S.L.; Boehm, R.; Blackstone, N.T.; El-Abbadi, N.H.; McNally Brandow, J.S.; Taylor, S.F.; DeLonge, M.S. Systematic review of dietary patterns and sustainability in the United States. Adv. Nutr. 2020, 11, 1016-1031. [CrossRef]

535. Resnick, D. Political economy of food system reform. Nat. Food 2020, 1, 154. [CrossRef]

536. Roig Vila, D. Towards sustainable diets: A multidisciplinary approach. Nutr. Hosp. 2020, 37, 43-46. [CrossRef]

537. Rosol, M. On the Significance of Alternative Economic Practices: Reconceptualizing Alterity in Alternative Food Networks. Econ. Geogr. 2020, 96, 52-76. [CrossRef]

538. Rossi, A. From Co-Learning to Shared Commitment to Agroecology. Some Insights from Initiatives Aimed at Reintroducing Agrobiodiversity. Sustainability 2020, 12, 7766. [CrossRef]

539. Sahal Alharbi, N.; Yahia Qattan, M.; Haji Alhaji, J. Towards Sustainable Food Services in Hospitals: Expanding the Concept of 'Plate Waste' to 'Tray Waste'. Sustainability 2020, 12, 6872. [CrossRef]

540. Sampedro, C.; Pizzitutti, F.; Quiroga, D.; Walsh, S.J.; Mena, C.F. Food supply system dynamics in the Galapagos Islands: Agriculture, livestock and imports. Renew. Agric. Food Syst. 2020, 35, 234-248. [CrossRef]

541. Schepelmann, P.; Vercalsteren, A.; Acosta-Fernandez, J.; Saurat, M.; Boonen, K.; Christis, M.; Marin, G.; Zoboli, R.; Maguire, C. Driving Forces of Changing Environmental Pressures from Consumption in the European Food System. Sustainability 2020, 12, 8265. [CrossRef]

542. Schiller, K.; Godek, W.; Klerkx, L.; Poortvliet, P.M. Nicaragua's agroecological transition: Transformation or reconfiguration of the agri-food regime? Agroecol. Sustain. Food Syst. 2020, 44, 611-628. [CrossRef]

543. Schoof, N.; Luick, R.; Jürgens, K.; Jones, G. Dairies in Germany: Key Factors for Grassland Conservation? Sustainability 2020, 12, 4139. [CrossRef]

544. Seidel, M. Sustainable Consumption graduate course: A project-based approach to learning. Food Cult. Soc. 2020, 23, 86-92 [CrossRef]

545. Sellberg, M.M.; Norström, A.V.; Peterson, G.D.; Gordon, L.J. Using local initiatives to envision sustainable and resilient food systems in the Stockholm city-region. Glob. Food Sec. 2020, 24, 100334. [CrossRef]

546. Sharma, M.; Kishore, A.; Roy, D.; Joshi, K. A comparison of the Indian diet with the EAT-Lancet reference diet. BMC Public Health 2020, 20, 812. [CrossRef]

547. Siegrist, M.; Hartmann, C. Consumer acceptance of novel food technologies. Nat. Food 2020, 1, 343-350. [CrossRef]

548. Sigurdsson, V.; Larsen, N.M.; Alemu, M.H.; Gallogly, J.K.; Menon, R.G.V.; Fagerstrøm, A. Assisting sustainable food consumption: The effects of quality signals stemming from consumers and stores in online and physical grocery retailing. J. Bus. Res. 2020, 112, 458-471. [CrossRef]

549. Simón-Rojo, M.; Couceiro, A.; del Valle, J.; Fariña Tojo, J. Public Food Procurement as a Driving Force for Building Local and Agroecological Food Systems: Farmers' Skepticism in Vega Baja del Jarama, Madrid (Spain). Land 2020, 9, 317. [CrossRef]

550. Smetana, S.; Aganovic, K.; Heinz, V. Food Supply Chains as Cyber-Physical Systems: A Path for More Sustainable Personalized Nutrition. Food Eng. Rev. 2020, 13, 92-103. [CrossRef]

551. Soma, T.; Li, B.; Maclaren, V. Food Waste Reduction: A Test of Three Consumer Awareness Interventions. Sustainability 2020, 12, 907. [CrossRef]

552. Sonnino, R.; Coulson, H. Unpacking the new urban food agenda: The changing dynamics of global governance in the urban age. Urban Stud. 2020, 004209802094203. [CrossRef] 
553. Stefanovic, L.; Freytag-Leyer, B.; Kahl, J. Food System Outcomes: An Overview and the Contribution to Food Systems Transformation. Front. Sustain. Food Syst. 2020, 4, 156. [CrossRef]

554. Sugimoto, M.; Murakami, K.; Fujiwara, A.; Asakura, K.; Masayasu, S.; Sasaki, S. Association between diet-related greenhouse gas emissions and nutrient intake adequacy among Japanese adults. PLoS ONE 2020, 15, e0240803. [CrossRef]

555. Tapsoba, P.K.; Aoudji, A.K.N.; Kabore, M.; Kestemont, M.-P.; Legay, C.; Achigan-Dako, E.G. Sociotechnical Context and Agroecological Transition for Smallholder Farms in Benin and Burkina Faso. Agronomy 2020, 10, 1447. [CrossRef]

556. Tittarelli, F. Organic Greenhouse Production: Towards an Agroecological Approach in the Framework of the New European Regulation-A Review. Agronomy 2020, 10, 72. [CrossRef]

557. Torres, A. For Young Consumers Farm-to-fork Is Not Organic: A Cluster Analysis of University Students. HortScience 2020, 55, 1475-1481. [CrossRef]

558. Tricarico, L.; Galimberti, A.; Campanaro, A.; Magoni, C.; Labra, M. Experimenting with RRI tools to Drive Sustainable Agri-Food Research: The SASS Case Study from Sub-Saharan Africa. Sustainability 2020, 12, 827. [CrossRef]

559. Triste, L.; Vandenabeele, J.; Lauwers, L.; Marchand, F. Strategies for expansive learning in sustainable farming initiatives: A CHAT analysis of a Dutch case. Int. J. Agric. Sustain. 2020, 18, 392-409. [CrossRef]

560. Ujuaje, M.D.; Chang, M. Systems of Food and Systems of Violence: An Intervention for the Special Issue on “Community Self Organisation, Sustainability and Resilience in Food Systems". Sustainability 2020, 12, 7092. [CrossRef]

561. Unger, K. How to empower people to co-create a healthy food system. J. Insects as Food Feed 2020, 6, 65-66. [CrossRef]

562. Valley, W.; Anderson, M.; Blackstone, N.T.; Sterling, E.; Betley, E.; Akabas, S.; Koch, P.; Dring, C.; Burke, J.; Spiller, K. Towards an equity competency model for sustainable food systems education programs. Elem. Sci. Anthr. 2020, 8, 33. [CrossRef]

563. Van de Vlasakker, P.C.H.; Veen, E.J. Effects of High-Tech Urban Agriculture on Cooking and Eating in Dutch Nursing Homes. Sustainability 2020, 12, 5379. [CrossRef]

564. Van der Gaast, K.; van Leeuwen, E.; Wertheim-Heck, S. City-Region Food Systems and Second Tier Cities: From Garden Cities to Garden Regions. Sustainability 2020, 12, 2532. [CrossRef]

565. Villa, P.M.; Martins, S.V.; de Oliveira Neto, S.N.; Rodrigues, A.C.; Hernández, E.P.; Kim, D.-G. Policy forum: Shifting cultivation and agroforestry in the Amazon: Premises for REDD+. For. Policy Econ. 2020, 118, 102217. [CrossRef]

566. Warshawsky, D.N. The Limits of Food Waste Governance in Cities: Case Study of Dayton, Ohio. Geogr. Rev. 2020, 111, 1-21. [CrossRef]

567. Weber, H.; Poeggel, K.; Eakin, H.; Fischer, D.; Lang, D.J.; Von Wehrden, H.; Wiek, A. What are the ingredients for food systems change towards sustainability?-Insights from the literature. Environ. Res. Lett. 2020, 15, 113001. [CrossRef]

568. Weidner, T.; Yang, A. The potential of urban agriculture in combination with organic waste valorization: Assessment of resource flows and emissions for two european cities. J. Clean. Prod. 2020, 244, 118490. [CrossRef]

569. Wezel, A.; Herren, B.G.; Kerr, R.B.; Barrios, E.; Gonçalves, A.L.R.; Sinclair, F. Agroecological principles and elements and their implications for transitioning to sustainable food systems. A review. Agron. Sustain. Dev. 2020, 40, 40. [CrossRef]

570. Wigboldus, S.; Brouwers, J.; Snel, H. How a Strategic Scoping Canvas Can Facilitate Collaboration between Partners in Sustainability Transitions. Sustainability 2019, 12, 168. [CrossRef]

571. Wynne-Jones, S.; Hyland, J.; Williams, P.; Chadwick, D. Collaboration for Sustainable Intensification: The Underpinning Role of Social Sustainability. Sociol. Rural. 2020, 60, 58-82. [CrossRef]

572. Yang, Y.; Hobbs, J.E.; Natcher, D.C. Assessing consumer willingness to pay for Arctic food products. Food Policy 2020, $92,101846$. [CrossRef]

573. Yang, Y.; Zhang, Y.; Huang, S. Urban Agriculture Oriented Community Planning and Spatial Modeling in Chinese Cities. Sustainability 2020, 12, 8735. [CrossRef]

574. Zafra-Aparici, E. A Sustainable World, An Integral Food Education. Agric. Soc. Desarro. 2020, 17, $349-373$.

575. Zhang, X.; Davidson, E.A.; Zou, T.; Lassaletta, L.; Quan, Z.; Li, T.; Zhang, W. Quantifying Nutrient Budgets for Sustainable Nutrient Management. Glob. Biogeochem. Cycles 2020, 34, e2018GB006060. [CrossRef]

576. Zhang, X.; Fang, Y.; Gao, Z. Accounting for Attribute Non-attendance (ANA) in Chinese Consumers' Away-from-Home Sustainable Salmon Consumption. Mar. Resour. Econ. 2020, 35, 263-284. [CrossRef]

577. Abu Hatab, A.; Cavinato, M.E.R.; Lindemer, A.; Lagerkvist, C.-J. Urban sprawl, food security and agricultural systems in developing countries: A systematic review of the literature. Cities 2019, 94, 129-142. [CrossRef]

578. Aleksandrowicz, L.; Green, R.; Joy, E.J.M.; Harris, F.; Hillier, J.; Vetter, S.H.; Smith, P.; Kulkarni, B.; Dangour, A.D.; Haines, A. Environmental impacts of dietary shifts in India: A modelling study using nationally-representative data. Environ. Int. 2019, 126, 207-215. [CrossRef]

579. Allen, T.; Prosperi, P.; Cogill, B.; Padilla, M.; Peri, I. A Delphi Approach to Develop Sustainable Food System Metrics. Soc. Indic. Res. 2019, 141, 1307-1339. [CrossRef]

580. Álvarez Castaño, L.S.; Cadavid Castro, M.A.; Quintero-Vergara, S.D.; Martínez-Bedoya, X.; Ríos Paniagua, L.M. Los consumidores de alimentos orgánicos ¿es posible construir política pública? Nutr. Hosp. 2019, 36, 640-646. [CrossRef]

581. Anderson, M.; Leach, M. Transforming Food Systems: The Potential of Engaged Political Economy. IDS Bull. 2019, 50, 131-146. [CrossRef] 
582. Anderson, C.A.M.; Thorndike, A.N.; Lichtenstein, A.H.; Van Horn, L.; Kris-Etherton, P.M.; Foraker, R.; Spees, C. Innovation to Create a Healthy and Sustainable Food System: A Science Advisory From the American Heart Association. Circulation 2019, 139, e1025-e1032. [CrossRef]

583. Anderson, C.R.; Maughan, C.; Pimbert, M.P. Transformative agroecology learning in Europe: Building consciousness, skills and collective capacity for food sovereignty. Agric. Hum. Values 2019, 36, 531-547. [CrossRef]

584. Anderson, C.R.; Bruil, J.; Chappell, M.J.; Kiss, C.; Pimbert, M.P. From Transition to Domains of Transformation: Getting to Sustainable and Just Food Systems through Agroecology. Sustainability 2019, 11, 5272. [CrossRef]

585. Arfini, F.; Antonioli, F.; Cozzi, E.; Donati, M.; Guareschi, M.; Mancini, M.C.; Veneziani, M. Sustainability, Innovation and Rural Development: The Case of Parmigiano-Reggiano PDO. Sustainability 2019, 11, 4978. [CrossRef]

586. Arfini, F.; Cozzi, E.; Mancini, M.C.; Ferrer-Perez, H.; Gil, J.M. Are Geographical Indication Products Fostering Public Goods? Some Evidence from Europe. Sustainability 2019, 11, 272. [CrossRef]

587. Asano, Y.M.; Biermann, G. Rising adoption and retention of meat-free diets in online recipe data. Nat. Sustain. 2019, 2, 621-627. [CrossRef]

588. Aschemann-Witzel, J.; Ares, G.; Thøgersen, J.; Monteleone, E. A sense of sustainability?_How sensory consumer science can contribute to sustainable development of the food sector. Trends Food Sci. Technol. 2019, 90, 180-186. [CrossRef]

589. Athanatos, J.; Mehrotra, I. Kaleidoscope of Nutrition Perspectives: From Food Security to Nutrition Security. Cereal Foods World 2019, 64. [CrossRef]

590. Béné, C.; Oosterveer, P.; Lamotte, L.; Brouwer, I.D.; de Haan, S.; Prager, S.D.; Talsma, E.F.; Khoury, C.K. When food systems meet sustainability-Current narratives and implications for actions. World Dev. 2019, 113, 116-130. [CrossRef]

591. Béné, C.; Prager, S.D.; Achicanoy, H.A.E.; Toro, P.A.; Lamotte, L.; Bonilla, C.; Mapes, B.R. Global map and indicators of food system sustainability. Sci. Data 2019, 6, 279. [CrossRef] [PubMed]

592. Benton, T.G. Using scenario analyses to address the future of food. EFSA J. 2019, 17, e170703. [CrossRef] [PubMed]

593. Bersamin, A.; Izumi, B.T.; Nu, J.; O’brien, D.M.; Paschall, M. Strengthening adolescents' connection to their traditional food system improves diet quality in remote Alaska Native communities: Results from the Neqa Elicarvigmun Pilot Study. Transl. Behav. Med. 2019, 9, 952-961. [CrossRef] [PubMed]

594. Blesh, J.; Hoey, L.; Jones, A.D.; Friedmann, H.; Perfecto, I. Development pathways toward "Zero Hunger". World Dev. 2019, 118, 1-14. [CrossRef]

595. Bogard, J.R.; Farmery, A.K.; Baird, D.L.; Hendrie, G.A.; Zhou, S. Linking Production and Consumption: The Role for Fish and Seafood in a Healthy and Sustainable Australian Diet. Nutrients 2019, 11, 1766. [CrossRef]

596. Boogaard, B.K. The relevance of connecting sustainable agricultural development with African philosophy. S. Afr. J. Philos. 2019, 38, 273-286. [CrossRef]

597. Boylan, S.; Sainsbury, E.; Thow, A.-M.; Degeling, C.; Craven, L.; Stellmach, D.; Gill, T.P.; Zhang, Y. A healthy, sustainable and safe food system: Examining the perceptions and role of the Australian policy actor using a Delphi survey. Public Health Nutr. 2019, 22, 2921-2930. [CrossRef]

598. Broad, G.M. Plant-based and cell-based animal product alternatives: An assessment and agenda for food tech justice. Geoforum 2019, 107, 223-226. [CrossRef]

599. Bronson, K.; Knezevic, I.; Clement, C. The Canadian family farm, in literature and in practice. J. Rural Stud. 2019, 66, 104-111. [CrossRef]

600. Bruckner, H.K.; Kowasch, M. Moralizing meat consumption: Bringing food and feeling into education for sustainable development. Policy Futur. Educ. 2019, 17, 785-804. [CrossRef]

601. Bush, S.R.; Belton, B.; Little, D.C.; Islam, M.S. Emerging trends in aquaculture value chain research. Aquaculture 2019, 498, 428-434. [CrossRef]

602. Canavan, C.R.; Fawzi, W.W. Addressing Knowledge Gaps in Adolescent Nutrition: Toward Advancing Public Health and Sustainable Development. Curr. Dev. Nutr. 2019, 3, nzz062. [CrossRef]

603. Capecchi, S.; Amato, M.; Sodano, V.; Verneau, F. Understanding beliefs and concerns towards palm oil: Empirical evidence and policy implications. Food Policy 2019, 89, 101785. [CrossRef]

604. Carlsson, L.; Callaghan, E.; Broman, G. How Can Dietitians Leverage Change for Sustainable Food Systems in Canada? Can. J. Diet. Pract. Res. 2019, 80, 164-171. [CrossRef] [PubMed]

605. Chandrakumar, C.; McLaren, S.J.; Jayamaha, N.P.; Ramilan, T. Absolute Sustainability-Based Life Cycle Assessment (ASLCA): A Benchmarking Approach to Operate Agri-food Systems within the $2{ }^{\circ} \mathrm{C}$ Global Carbon Budget. J. Ind. Ecol. 2019, $23,906-917$. [CrossRef]

606. Chojnacki, K.; Creamer, N. Governance and Innovations in Local Food System Development: A Bottom-Up Approach in North Carolina. J. Agric. Food Syst. Community Dev. 2019, 9, 239-240. [CrossRef]

607. Chopra, S. HCI for Participatory Futuring in Sustainable Communities. In Proceedings of the Extended Abstracts of the 2019 CHI Conference on Human Factors in Computing Systems, Glasgow, UK, 4-9 May 2019; ACM: New York, NY, USA, 2019; pp. $1-6$.

608. Christman, S. ALT-BURGER Transforming Populist Food systems. Krit. Kult. 2019, 641-666. [CrossRef]

609. Colinas, J.; Bush, P.; Manaugh, K. The socio-environmental impacts of public urban fruit trees: A Montreal case-study. Urban For. Urban Green. 2019, 45, 126132. [CrossRef] 
610. Corallo, A.; Latino, M.E.; Menegoli, M.; Spennato, A. A Survey to Discover Current Food Choice Behaviors. Sustainability 2019, 11, 5041. [CrossRef]

611. Corallo, A.; Latino, M.E.; Menegoli, M.; De Devitiis, B.; Viscecchia, R. Human Factor in Food Label Design to Support Consumer Healthcare and Safety: A Systematic Literature Review. Sustainability 2019, 11, 4019. [CrossRef]

612. Corke, H.; Olewnik, M. Looking at the Global Food System with an Analytical Lens. Cereal Foods World 2019, 64. [CrossRef]

613. Corrado, S.; Caldeira, C.; Eriksson, M.; Hanssen, O.J.; Hauser, H.-E.; van Holsteijn, F.; Liu, G.; Östergren, K.; Parry, A.; Secondi, L.; et al. Food waste accounting methodologies: Challenges, opportunities, and further advancements. Glob. Food Sec. 2019, 20, 93-100. [CrossRef] [PubMed]

614. Coteur, I.; Marchand, F.; Debruyne, L.; Lauwers, L. Structuring the myriad of sustainability assessments in agri-food systems: A case in Flanders. J. Clean. Prod. 2019, 209, 472-480. [CrossRef]

615. Cottrell, R.S.; Nash, K.L.; Halpern, B.S.; Remenyi, T.A.; Corney, S.P.; Fleming, A.; Fulton, E.A.; Hornborg, S.; Johne, A.; Watson, R.A.; et al. Food production shocks across land and sea. Nat. Sustain. 2019, 2, 130-137. [CrossRef]

616. Cramer, S.E.; Ball, A.L.; Hendrickson, M.K. “Our school system is trying to be agrarian”: Educating for reskilling and food system transformation in the rural school garden. Agric. Human Values 2019, 36, 507-519. [CrossRef]

617. Dawson, I.K.; Park, S.E.; Attwood, S.J.; Jamnadass, R.; Powell, W.; Sunderland, T.; Carsan, S. Contributions of biodiversity to the sustainable intensification of food production. Glob. Food Sec. 2019, 21, 23-37. [CrossRef]

618. De Krom, M.P.M.M.; Muilwijk, H. Multiplicity of Perspectives on Sustainable Food: Moving Beyond Discursive Path Dependency in Food Policy. Sustainability 2019, 11, 2773. [CrossRef]

619. De la Salle, J. Great food streets: Planning and design for urban magnetism in post-agricultural cities. URBAN Des. Int. 2019, 24, 118-128. [CrossRef]

620. Derqui, B. Education for Sustainable Development. The Issue of Food Waste at School Canteens. In Proceedings of the 13th International Technology, Education and Development Conference (INTED2019), Valencia, Spain, 11-13 March 2019; Chova, L.G., Martinez, A.L., Torres, I.C., Eds.; IATED-Int. Assoc. Technology Education \& Development: Valenica, Spain, 2019; pp. 1550-1556.

621. Derunova, E.; Kireeva, N.; Pruschak, O. Typology of Regions According to the Level of Food Security: Methodological Approaches and Solutions. Sci. Pap. Manag. Econ. Eng. Agric. Rural Dev. 2019, 19, 135-146.

622. Drejerska, N.; Bareja-Wawryszuk, O.; Gołębiewski, J. Marginal, localized and restricted activity. Br. Food J. 2019, 121, 1368-1381. [CrossRef]

623. Egolf, A.; Hartmann, C.; Siegrist, M. When Evolution Works Against the Future: Disgust's Contributions to the Acceptance of New Food Technologies. Risk Anal. 2019, 39, 1546-1559. [CrossRef]

624. Eker, S.; Reese, G.; Obersteiner, M. Modelling the drivers of a widespread shift to sustainable diets. Nat. Sustain. 2019, 2, 725-735. [CrossRef]

625. El Bilali, H. The Multi-Level Perspective in Research on Sustainability Transitions in Agriculture and Food Systems: A Systematic Review. Agriculture 2019, 9, 74. [CrossRef]

626. El Bilali, H. Research on agro-food sustainability transitions: A systematic review of research themes and an analysis of research gaps. J. Clean. Prod. 2019, 221, 353-364. [CrossRef]

627. Esculier, F.; Le Noë, J.; Barles, S.; Billen, G.; Créno, B.; Garnier, J.; Lesavre, J.; Petit, L.; Tabuchi, J.-P. The biogeochemical imprint of human metabolism in Paris Megacity: A regionalized analysis of a water-agro-food system. J. Hydrol. 2019, 573, 1028-1045. [CrossRef]

628. Fanzo, J.; Davis, C. Can Diets Be Healthy, Sustainable, and Equitable? Curr. Obes. Rep. 2019, 8, 495-503. [CrossRef]

629. Ferrari, L.; Cavaliere, A.; De Marchi, E.; Banterle, A. Can nudging improve the environmental impact of food supply chain? A systematic review. Trends Food Sci. Technol. 2019, 91, 184-192. [CrossRef]

630. Finley, J.W.; Fukagawa, N.K. Integrated data across multiple and diverse disciplines are essential for developing a sustainable food system. J. Soil Water Conserv. 2019, 74, 632-638. [CrossRef]

631. Fridman, D.; Kissinger, M. A multi-scale analysis of interregional sustainability: Applied to Israel's food supply. Sci. Total Environ. 2019, 676, 524-534. [CrossRef]

632. Gaitán-Cremaschi, D.; Klerkx, L.; Duncan, J.; Trienekens, J.H.; Huenchuleo, C.; Dogliotti, S.; Contesse, M.E.; Rossing, W.A.H. Characterizing diversity of food systems in view of sustainability transitions. A review. Agron. Sustain. Dev. 2019, 39, 1447-1459. [CrossRef]

633. Garcia-Garcia, G.; Woolley, E.; Rahimifard, S. Identification and Analysis of Attributes for Industrial Food Waste Management Modelling. Sustainability 2019, 11, 2445. [CrossRef]

634. Garcia-Gonzalez, J.; Eakin, H. What Can Be: Stakeholder Perspectives for a Sustainable Food System. J. Agric. Food Syst. Community Dev. 2019, 8, 61-82. [CrossRef]

635. García-Sempere, A.; Morales, H.; Hidalgo, M.; Ferguson, B.G.; Rosset, P.; Nazar-Beutelspacher, A. Food Sovereignty in the city?: A methodological proposal for evaluating food sovereignty in urban settings. Agroecol. Sustain. Food Syst. 2019, 43, $1145-1173$. [CrossRef]

636. Ge, H.; Canning, P.; Goetz, S.; Perez, A.; Li, J. Embedding Economies of Scale Concepts in the Model of Optimal Locations of Fresh Produce Aggregation Hubs. Agric. Resour. Econ. Rev. 2019, 48, 365-387. [CrossRef] 
637. Gentry, R.R.; Ruff, E.O.; Lester, S.E. Temporal patterns of adoption of mariculture innovation globally. Nat. Sustain. 2019, 2, 949-956. [CrossRef]

638. Ghinea, C.; Ghiuta, O.-A. Household food waste generation: Young consumers behaviour, habits and attitudes. Int. J. Environ. Sci. Technol. 2019, 16, 2185-2200. [CrossRef]

639. Gillespie, S.; van den Bold, M.; Hodge, J. Nutrition and the governance of agri-food systems in South Asia: A systematic review. Food Policy 2019, 82, 13-27. [CrossRef]

640. Gliessman, S.; Friedmann, H.H.; Howard, P. Agroecology and Food Sovereignty. IDS Bull. 2019, 50, 91-110. [CrossRef]

641. Grant, M.; Gilgen, A.K.; Buchmann, N. The Rich Picture Method: A Simple Tool for Reflective Teaching and Learning about Sustainable Food Systems. Sustainability 2019, 11, 4815. [CrossRef]

642. Gustafson, D.I.; Edge, M.S.; Griffin, T.S.; Kendall, A.M.; Kass, S.D. Growing Progress in the Evolving Science, Business, and Policy of Sustainable Nutrition. Curr. Dev. Nutr. 2019, 3, nzz059. [CrossRef] [PubMed]

643. Gwin, L. Out of Our Silos, Into the Movement: Community Food Systems and Cooperative Extension in Oregon. J. Agric. Food Syst. Community Dev. 2019, 9, 231-232. [CrossRef]

644. Halbe, J.; Adamowski, J. Modeling sustainability visions: A case study of multi-scale food systems in Southwestern Ontario. J. Environ. Manag. 2019, 231, 1028-1047. [CrossRef]

645. Haysom, G.; Olsson, E.G.A.; Dymitrow, M.; Opiyo, P.; Taylor Buck, N.; Oloko, M.; Spring, C.; Fermskog, K.; Ingelhag, K.; Kotze, S.; et al. Food systems sustainability: An examination of different viewpoints on food system change. Sustainability 2019, 11, 3337. [CrossRef]

646. Haythorn, C.; Knudsen, D.; Farmer, J.; Antreasian, C.; Betz, M. It's All in the SKU: Getting food from somewhere from the field to the dinner plate while using a large scale retailer. Sustainability 2019, 11, 892. [CrossRef]

647. Henchion, M.; McCarthy, M.; Dillon, E.J.; Greehy, G.; McCarthy, S.N. Big issues for a small technology: Consumer trade-offs in acceptance of nanotechnology in food. Innov. Food Sci. Emerg. Technol. 2019, 58, 102210. [CrossRef]

648. Huang, C.-L.; Qu, S.; Gao, B.; Huang, Y.; Fang, H.; Yan, X.; Cui, S.; Xu, M. Effects of urbanization on phosphorus metabolism in a typical agricultural area. J. Clean. Prod. 2019, 214, 803-815. [CrossRef]

649. Hubeau, M.; Vanderplanken, K.; Vandermoere, F.; Rogge, E.; Van Huylenbroeck, G.; Marchand, F. Sharing is caring: The role of culture in the transformative capacity and continuation of agri-food networks. Environ. Innov. Soc. Transit. 2019, 33, 127-139. [CrossRef]

650. Jacobi, J.; Mukhovi, S.; Llanque, A.; Toledo, D.; Speranza, C.I.; Käser, F.; Augstburger, H.; Delgado, J.M.F.; Kiteme, B.P.; Rist, S. Actor-specific risk perceptions and strategies for resilience building in different food systems in Kenya and Bolivia. Reg. Environ. Chang. 2019, 19, 879-892. [CrossRef]

651. Janssens, K.; Lambrechts, W.; van Osch, A.; Semeijn, J. How Consumer Behavior in Daily Food Provisioning Affects Food Waste at Household Level in the Netherlands. Foods 2019, 8, 428. [CrossRef]

652. Jeric, S.V.; Soric, K. Multi-Objective Optimization for the Integrated Supply and Production Planning in Olive Oil Industry. Ekon. Vjesn. 2019, 32, 129-138.

653. Jin, L.; Chang, Y.; Ju, X.; Xu, F. A Study on the Sustainable Development of Water, Energy, and Food in China. Int. J. Environ. Res. Public Health 2019, 16, 3688. [CrossRef]

654. Jones, R.; Wham, C.; Burlingame, B. New Zealand's food system is unsustainable: A survey of the divergent attitudes of agriculture, environment, and health sector professionals towards eating guidelines. Front. Nutr. 2019, 6. [CrossRef]

655. Klerkx, L.; Jakku, E.; Labarthe, P. A review of social science on digital agriculture, smart farming and agriculture 4.0: New contributions and a future research agenda. NJAS Wagening. J. Life Sci. 2019, 90-91, 100315. [CrossRef]

656. Kok, K.P.W.; den Boer, A.C.L.; Cesuroglu, T.; van der Meij, M.G.; de Wildt-Liesveld, R.; Regeer, B.J.; Broerse, J.E.W. Transforming Research and Innovation for Sustainable Food Systems-A Coupled-Systems Perspective. Sustainability 2019, 11, 7176. [CrossRef]

657. Kuokkanen, A.; Uusitalo, V.; Koistinen, K. A framework of disruptive sustainable innovation: An example of the Finnish food system. Technol. Anal. Strateg. Manag. 2019, 31, 749-764. [CrossRef]

658. Lahatte, A.; de Turckheim, E.; Chalumeau, L. Designing healthy and sustainable food systems: How is research contributing? In Proceedings of the 17th International Conference of the International-Society-for-Scientometrics-and-Informetrics (ISSI) on Scientometrics and Informetrics, Rome, Italy, 2-5 September 2019; Daraio, C., Gregori, M., Moed, H., Ruocco, G., Eds.; International Society for Scientometrics \& Informetrics-ISSI: Leuven, Belgium, 2019; pp. 523-534.

659. Lee, H.; Brown, C.; Seo, B.; Holman, I.; Audsley, E.; Cojocaru, G.; Rounsevell, M. Implementing land-based mitigation to achieve the Paris Agreement in Europe requires food system transformation. Environ. Res. Lett. 2019, 14, 104009. [CrossRef]

660. Li, L.; Li, G.; Feng, X.; Liu, Z.; Tsai, F.-S. Moderating Effect of Dynamic Environment in the Relationship between Guanxi, Trust, and Repurchase Intention of Agricultural Materials. Int. J. Environ. Res. Public Health 2019, 16, 3773. [CrossRef]

661. Linder, T. Making the case for edible microorganisms as an integral part of a more sustainable and resilient food production system. Food Secur. 2019, 11, 265-278. [CrossRef]

662. Machida, D.; Yoshida, T. Factors that Affect Nonmarket Fruit and Vegetable Receptions: Analyses of Two Cross-Sectional Surveys in Gunma, Japan. Agriculture 2019, 9, 230. [CrossRef]

663. Marsden, T.; Moragues Faus, A.; Sonnino, R. Reproducing vulnerabilities in agri-food systems: Tracing the links between governance, financialization, and vulnerability in Europe post 2007-2008. J. Agrar. Chang. 2019, 19, 82-100. [CrossRef] 
664. Martinelli, S.S.; Cavalli, S.B. Alimentação saudável e sustentável: Uma revisão narrativa sobre desafios e perspectivas. Cien. Saude Colet. 2019, 24, 4251-4262. [CrossRef] [PubMed]

665. Mawois, M.; Vidal, A.; Revoyron, E.; Casagrande, M.; Jeuffroy, M.-H.; Le Bail, M. Transition to legume-based farming systems requires stable outlets, learning, and peer-networking. Agron. Sustain. Dev. 2019, 39, 14. [CrossRef]

666. McInnes, A. Integrating sustainability transitions and food systems research to examine consultation failures in Canadian food policymaking. J. Environ. Policy Plan. 2019, 21, 407-426. [CrossRef]

667. Meier, C.; Oehen, B. Consumers' Valuation of Farmers' Varieties for Food System Diversity. Sustainability 2019, $11,7134$. [CrossRef]

668. Menozzi, D.; Finardi, C. May trust and solidarity defy food scares? The case of Parmigiano-Reggiano PDO sales in the aftermath of natural disaster. Br. Food J. 2019, 121, 3119-3134. [CrossRef]

669. Mohapatra, S.; Mishra, S.S.; Bhalla, P.; Thatoi, H. Engineering grass biomass for sustainable and enhanced bioethanol production. Planta 2019, 250, 395-412. [CrossRef]

670. Nemes, G.; Csizmadiáné Czuppon, V.; Kujáni, K.; Orbán, É.; Szegedyné Fricz, Á.; Lajos, V. The local food system in the 'genius loci'-The role of food, local products and short food chains in rural tourism. Stud. Agric. Econ. 2019, 121, 111-118. [CrossRef]

671. Neves, T.L.; Alvarenga, C.B.C.S.; Engler, R.d.C.; Aguilar, M.T.P.; Sales, R.d.B.C. Sistema alimentar: Um estudo comparativo de Sistemas Produto-Serviço para produção, distribuição e comercialização de alimentos. Urbe. Rev. Bras. Gestão Urbana $2019,11$. [CrossRef]

672. Nikmaram, N.; Rosentrater, K.A. Overview of Some Recent Advances in Improving Water and Energy Efficiencies in Food Processing Factories. Front. Nutr. 2019, 6, 20. [CrossRef]

673. Noy, S.; Patrick, R.; Henderson-Wilson, C.; Nuttman, S.; Ryan, I. New frontiers in community initiatives to increase vegetable consumption. Health Promot. J. Aust. 2019, 30, 52-61. [CrossRef]

674. Osman, M.; Nelson, W. How can food futures insight promote change in consumers' choices, are behavioural interventions (e.g., nudges) the answer? Futures 2019, 111, 116-122. [CrossRef]

675. Palumbo, R.; Adinolfi, P.; Annarumma, C.; Catinello, G.; Tonelli, M.; Troiano, E.; Vezzosi, S.; Manna, R. Unravelling the food literacy puzzle: Evidence from Italy. Food Policy 2019, 83, 104-115. [CrossRef]

676. Pihlajamaki, M.; Asikainen, A.; Ignatius, S.; Haapasaari, P.; Tuomisto, J.T. Forage Fish as Food: Consumer Perceptions on Baltic Herring. Sustainability 2019, 11, 4298. [CrossRef]

677. Pulker, C.E.; Trapp, G.S.A.; Scott, J.A. Pollard The Nature and Quality of Australian Supermarkets' Policies that can Impact Public Health Nutrition, and Evidence of their Practical Application: A Cross-Sectional Study. Nutrients 2019, 11, 853. [CrossRef]

678. Raheem, D.; Shishaev, M.; Dikovitsky, V. Food System Digitalization as a Means to Promote Food and Nutrition Security in the Barents Region. Agriculture 2019, 9, 168. [CrossRef]

679. Ramankutty, N.; Ricciardi, V.; Mehrabi, Z.; Seufert, V. Trade-offs in the performance of alternative farming systems. Agric. Econ. 2019, 50, 97-105. [CrossRef]

680. Reynolds, C.; Goucher, L.; Quested, T.; Bromley, S.; Gillick, S.; Wells, V.K.; Evans, D.; Koh, L.; Carlsson Kanyama, A.; Katzeff, C.; et al. Review: Consumption-stage food waste reduction interventions-What works and how to design better interventions. Food Policy 2019, 83, 7-27. [CrossRef]

681. Ridoutt, B.; Bogard, J.R.; Dizyee, K.; Lim-Camacho, L.; Kumar, S. Value Chains and Diet Quality: A Review of Impact Pathways and Intervention Strategies. Agriculture 2019, 9, 185. [CrossRef]

682. Rohmer, S.U.K.; Gerdessen, J.C.; Claassen, G.D.H. Sustainable supply chain design in the food system with dietary considerations: A multi-objective analysis. Eur. J. Oper. Res. 2019, 273, 1149-1164. [CrossRef]

683. Rose, N.; Lourival, I. Hegemony, Counter-Hegemony and Food Systems Literacy: Transforming the Global Industrial Food System. Aust. J. Environ. Educ. 2019, 35, 110-122. [CrossRef]

684. Rose, D.; Heller, M.C.; Roberto, C.A. Position of the Society for Nutrition Education and Behavior: The Importance of Including Environmental Sustainability in Dietary Guidance. J. Nutr. Educ. Behav. 2019, 51, 3-15.e1. [CrossRef]

685. Rotz, S.; Duncan, E.; Small, M.; Botschner, J.; Dara, R.; Mosby, I.; Reed, M.; Fraser, E.D.G. The Politics of Digital Agricultural Technologies: A Preliminary Review. Sociol. Rural. 2019, 59, 203-229. [CrossRef]

686. Royo-Bordonada, M.Á.; Rodríguez-Artalejo, F.; Bes-Rastrollo, M.; Fernández-Escobar, C.; González, C.A.; Rivas, F.; Martínez-González, M.Á.; Quiles, J.; Bueno-Cavanillas, A.; Navarrete-Muñoz, E.M.; et al. Políticas alimentarias para prevenir la obesidad y las principales enfermedades no transmisibles en España: Querer es poder. Gac. Sanit. 2019, 33, 584-592. [CrossRef]

687. Sambell, R.; Andrew, L.; Godrich, S.; Wolfgang, J.; Vandenbroeck, D.; Stubley, K.; Rose, N.; Newman, L.; Horwitz, P.; Devine, A. Local Challenges and Successes Associated with Transitioning to Sustainable Food System Practices for a West Australian Context: Multi-Sector Stakeholder Perceptions. Int. J. Environ. Res. Public Health 2019, 16, 2051. [CrossRef]

688. Schanes, K.; Stagl, S. Food waste fighters: What motivates people to engage in food sharing? J. Clean. Prod. 2019, $211,1491-1501$. [CrossRef]

689. Schier, H.E.; Eliot, K.A.; Herron, S.A.; Landfried, L.K.; Migicovsky, Z.; Rubin, M.J.; Miller, A.J. Comparative Analysis of Perennial and Annual Phaseolus Seed Nutrient Concentrations. Sustainability 2019, 11, 2787. [CrossRef]

690. Schreiber, L.; Gold, A.; Anfinson, A.; Boelcke-Stennes, K.; Caspi, C.; Chalise, N.; Dahl, M.; Hane, A.; Jenkins, T.; Marczak, M.; et al. Creating a Food System Report Card to Advance the Minnesota Food System. J. Agric. Food Syst. Community Dev. 2019, 9 , 241-242. [CrossRef] 
691. Shilomboleni, H.; Owaygen, M.; De Plaen, R.; Manchur, W.; Husak, L. Scaling up innovations in smallholder agriculture: Lessons from the Canadian international food security research fund. Agric. Syst. 2019, 175, 58-65. [CrossRef]

692. Si, Z.; Scott, S. China's changing food system: Top-down and bottom-up forces in food system transformations. Can. J. Dev. Stud. 2019, 40, 1-11. [CrossRef]

693. Silva, V.L.; Sanjuán, N. Opening up the black box: A systematic literature review of life cycle assessment in alternative food processing technologies. J. Food Eng. 2019, 250, 33-45. [CrossRef]

694. Sipple, D.; Schanz, H. Nachhaltige Stadtentwicklung über kommunale Ernährungssysteme: Marktakteursnetzwerke als Ansatzpunkte zur Gestaltung und Steuerung. Z. Wirtschgeogr. 2019, 63, 1-22. [CrossRef]

695. Smetana, S.M.; Bornkessel, S.; Heinz, V. A Path From Sustainable Nutrition to Nutritional Sustainability of Complex Food Systems. Front. Nutr. 2019, 6, 39. [CrossRef]

696. Smetana, S.; Schmitt, E.; Mathys, A. Sustainable use of Hermetia illucens insect biomass for feed and food: Attributional and consequential life cycle assessment. Resour. Conserv. Recycl. 2019, 144, 285-296. [CrossRef]

697. Smith, K.; Ostrom, M.; McMoran, D.; Carpenter-Boggs, L. Connecting New Farmers to Place, Agroecology, and Community through a Bilingual Organic Farm Incubator. J. Agric. Food Syst. Community Dev. 2019, 9, 111-124. [CrossRef]

698. Sodano, V. Innovation Trajectories and Sustainability in the Food System. Sustainability 2019, 11, 1271. [CrossRef]

699. Subramaniam, Y.; Masron, T.A. Food security and environmental degradation: Evidence from developing countries. GeoJournal 2019. [CrossRef]

700. Swagemakers, P.; Domínguez García, M.D.; Milone, P.; Ventura, F.; Wiskerke, J.S.C. Exploring cooperative place-based approaches to restorative agriculture. J. Rural Stud. 2019, 68, 191-199. [CrossRef]

701. Takiya, C.S.; Ylioja, C.M.; Bennett, A.; Davidson, M.J.; Sudbeck, M.; Wickersham, T.A.; VandeHaar, M.J.; Bradford, B.J. Feeding Dairy Cows With "Leftovers" and the Variation in Recovery of Human-Edible Nutrients in Milk. Front. Sustain. Food Syst. 2019, 3, 114. [CrossRef]

702. Tlusty, M.F.; Tyedmers, P.; Bailey, M.; Ziegler, F.; Henriksson, P.J.G.; Béné, C.; Bush, S.; Newton, R.; Asche, F.; Little, D.C.; et al. Reframing the sustainable seafood narrative. Glob. Environ. Chang. 2019, 59, 101991. [CrossRef]

703. Valencia, V.; Wittman, H.; Blesh, J. Structuring markets for resilient farming systems. Agron. Sustain. Dev. 2019, 39, 25. [CrossRef]

704. Van Bers, C.; Delaney, A.; Eakin, H.; Cramer, L.; Purdon, M.; Oberlack, C.; Evans, T.; Pahl-Wostl, C.; Eriksen, S.; Jones, L.; et al. Advancing the research agenda on food systems governance and transformation. Curr. Opin. Environ. Sustain. 2019, 39, 94-102. [CrossRef]

705. Van Hal, O.; Weijenberg, A.A.A.; de Boer, I.J.M.; van Zanten, H.H.E. Accounting for feed-food competition in environmental impact assessment: Towards a resource efficient food-system. J. Clean. Prod. 2019, 240, 118241. [CrossRef]

706. Verneau, F.; La Barbera, F.; Amato, M.; Sodano, V. Consumers' concern towards palm oil consumption. Br. Food J. 2019, 121, 1982-1997. [CrossRef]

707. Vieira, L.C.; Serrao-Neumann, S.; Howes, M. Local Action with a Global Vision: The transformative potential of food social enterprises in Australia. Sustainability 2019, 11, 6756. [CrossRef]

708. Virah-Sawmy, M.; Durán, A.P.; Green, J.M.H.; Guerrero, A.M.; Biggs, D.; West, C.D. Sustainability gridlock in a global agricultural commodity chain: Reframing the soy-meat food system. Sustain. Prod. Consum. 2019, 18, 210-223. [CrossRef]

709. Visser, O.; Dorondel, S.; Jehlička, P.; Spoor, M. Post-socialist smallholders: Silence, resistance and alternatives. Can. J. Dev. Stud. 2019, 40, 499-510. [CrossRef]

710. Voinea, L.; Vrânceanu, D.M.; Filip, A.; Popescu, D.V.; Negrea, T.M.; Dina, R. Research on Food Behavior in Romania from the Perspective of Supporting Healthy Eating Habits. Sustainability 2019, 11, 5255. [CrossRef]

711. Waage, J.; Cornelsen, L.; Dangour, A.D.; Green, R.; Häsler, B.; Hull, E.; Johnston, D.; Kadiyala, S.; Lock, K.; Shankar, B.; et al Integrating Agriculture and Health Research for Development: LCIRAH as an Interdisciplinary Programme to Address a Global Challenge. Glob. Challenges 2019, 3, 1700104. [CrossRef]

712. Warne, T.; Ahmed, S.; Byker Shanks, C.; Miller, P. Sustainability Dimensions of a North American Lentil System in a Changing World. Front. Sustain. Food Syst. 2019, 3, 88. [CrossRef]

713. Warshawsky, D.N. The Challenge of Food Waste Governance in Cities: Case Study of Consumer Perspectives in Los Angeles. Sustainability 2019, 11, 847. [CrossRef]

714. Warshawsky, D.; Vos, R. Governing at Scale: Successful Local Food Initiatives in the World's Cities. Sustainability 2019, 11, 7226. [CrossRef]

715. Weidner, T.; Yang, A.; Hamm, M.W. Consolidating the current knowledge on urban agriculture in productive urban food systems: Learnings, gaps and outlook. J. Clean. Prod. 2019, 209, 1637-1655. [CrossRef]

716. Wetherill, M.S.; White, K.C.; Seligman, H.K. Nutrition-Focused Food Banking in the United States: A Qualitative Study of Healthy Food Distribution Initiatives. J. Acad. Nutr. Diet. 2019, 119, 1653-1665. [CrossRef]

717. Ahmed, S.; Byker Shanks, C.; Lewis, M.; Leitch, A.; Spencer, C.; Smith, E.M.; Hess, D. Meeting the food waste challenge in higher education. Int. J. Sustain. High. Educ. 2018, 19, 1075-1094. [CrossRef]

718. Ameso, E.; Bukachi, S.; Olungah, C.; Haller, T.; Wandibba, S.; Nangendo, S. Pastoral Resilience among the Maasai Pastoralists of Laikipia County, Kenya. Land 2018, 7, 78. [CrossRef]

719. Ball, B.C.; Hargreaves, P.R.; Watson, C.A. A framework of connections between soil and people can help improve sustainability of the food system and soil functions. AMBIO 2018, 47, 269-283. [CrossRef] 
720. Barnhill, A.; Palmer, A.; Weston, C.M.; Brownell, K.D.; Clancy, K.; Economos, C.D.; Gittelsohn, J.; Hammond, R.A.; Kumanyika, S.; Bennett, W.L. Grappling With Complex Food Systems to Reduce Obesity: A US Public Health Challenge. Public Health Rep. 2018, 133, 44S-53S. [CrossRef]

721. Bertrand, C.; Lesturgeon, A.; Amiot, M.-J.; Dimier-Vallet, C.; Dufeu, I.; Habersetzer, T.; Lairon, D.; Majou, D.; Mondejar, G.; Taupier-Letage, B.; et al. Alimentation biologique: État des lieux et perspectives. Cah. Nutr. Diététique 2018, 53, 141-150. [CrossRef]

722. Blazquez, D.; Domenech, J.; Garcia-Alvarez-Coque, J.-M. Assessing Technology Platforms for Sustainability with Web Data Mining Techniques. Sustainability 2018, 10, 4497. [CrossRef]

723. Brekken, C.; Peterson, H.; King, R.; Conner, D. Writing a Recipe for Teaching Sustainable Food Systems: Lessons from Three University Courses. Sustainability 2018, 10, 1898. [CrossRef]

724. Brinkley, C. The Small World of the Alternative Food Network. Sustainability 2018, 10, 2921. [CrossRef]

725. Bureau, S.; Gouble, B.; Audergon, J.M.; Costa, S.; Tozanli, S. The ILLIAD project: Sustainable, local or localized, innovative food chains-Application to apricot production. Acta Hortic. 2018, 1214, 39-44. [CrossRef]

726. Butrico, G.M.; Kaplan, D.H. Greenhouse Agriculture in the Icelandic Food System. Eur. Countrys. 2018, 10, 711-724. [CrossRef]

727. Campling, L.; Havice, E. The Global Environmental Politics and Political Economy of Seafood Systems. Glob. Environ. Polit. 2018, 18, 72-92. [CrossRef]

728. Castrica, M.; Tedesco, D.; Panseri, S.; Ferrazzi, G.; Ventura, V.; Frisio, D.; Balzaretti, C. Pet Food as the Most Concrete Strategy for Using Food Waste as Feedstuff within the European Context: A Feasibility Study. Sustainability 2018, 10, 2035. [CrossRef]

729. Cerrada-Serra, P.; Moragues-Faus, A.; Zwart, T.A.; Adlerova, B.; Ortiz-Miranda, D.; Avermaete, T. Exploring the contribution of alternative food networks to food security. A comparative analysis. Food Secur. 2018, 10, 1371-1388. [CrossRef]

730. Chabin, T.; Barnabé, M.; Boukhelifa, N.; Fonseca, F.; Tonda, A.; Velly, H.; Lemaitre, B.; Perrot, N.; Lutton, E. LIDeOGraM: An Interactive Evolutionary Modelling Tool; Springer: Cham, Switzerland, 2018; pp. 189-201.

731. Chen, J.; Yu, X.; Qiu, L.; Deng, M.; Dong, R. Study on Vulnerability and Coordination of Water-Energy-Food System in Northwest China. Sustainability 2018, 10, 3712. [CrossRef]

732. Chowdhury, R.B.; Moore, G.A.; Weatherley, A.J. A multi-year phosphorus flow analysis of a key agricultural region in Australia to identify options for sustainable management. Agric. Syst. 2018, 161, 42-60. [CrossRef]

733. Clapp, J. Mega-Mergers on the Menu: Corporate Concentration and the Politics of Sustainability in the Global Food System. Glob. Environ. Polit. 2018, 18, 12-33. [CrossRef]

734. Clapp, J.; Isakson, S.R. Risky Returns: The Implications of Financialization in the Food System. Dev. Change 2018, 49, 437-460. [CrossRef]

735. French Collier, N.; Sayer, J.; Boedhihartono, A.; Hanspach, J.; Abson, D.; Fischer, J. System Properties Determine Food Security and Biodiversity Outcomes at Landscape Scale: A Case Study from West Flores, Indonesia. Land 2018, 7, 39. [CrossRef]

736. Conrad, Z.; Johnson, L.K.; Peters, C.J.; Jahns, L. Capacity of the US Food System to Accommodate Improved Diet Quality: A Biophysical Model Projecting to 2030. Curr. Dev. Nutr. 2018, 2, nzy007. [CrossRef]

737. Corrado, S.; Sala, S. Food waste accounting along global and European food supply chains: State of the art and outlook. Waste Manag. 2018, 79, 120-131. [CrossRef]

738. Dame, J. Food Security and Translocal Livelihoods in High Mountains: Evidence from Ladakh, India. Mt. Res. Dev. 2018, 38 , 310. [CrossRef]

739. Dantas, M.; Silva, G. The Xique-Xique Network towards sustainability and solidarity. IOP Conf. Ser. Earth Environ. Sci. 2018, 151, 012014. [CrossRef]

740. Davis, K.F.; Chiarelli, D.D.; Rulli, M.C.; Chhatre, A.; Richter, B.; Singh, D.; DeFries, R. Alternative cereals can improve water use and nutrient supply in India. Sci. Adv. 2018, 4, eaao1108. [CrossRef]

741. Delaney, A.; Evans, T.; McGreevy, J.; Blekking, J.; Schlachter, T.; Korhonen-Kurki, K.; Tamás, P.A.; Crane, T.A.; Eakin, H.; Förch, W.; et al. Governance of food systems across scales in times of social-ecological change: A review of indicators. Food Secur. 2018, 10, 287-310. [CrossRef]

742. Dermody, B.J.; Sivapalan, M.; Stehfest, E.; van Vuuren, D.P.; Wassen, M.J.; Bierkens, M.F.P.; Dekker, S.C. A framework for modelling the complexities of food and water security under globalisation. Earth Syst. Dyn. 2018, 9, 103-118. [CrossRef]

743. Derqui, B.; Fernandez, V.; Fayos, T. Towards more sustainable food systems. Addressing food waste at school canteens. Appetite 2018, 129, 1-11. [CrossRef]

744. Díaz, E.M.; Reigada, A. Intensive agriculture under plastic in Andalusia (Spain): A production model in question. Int. J. Iber. Stud. 2018, 31, 183-201. [CrossRef]

745. Drewnowski, A. The Chicago Consensus on Sustainable Food Systems Science. Front. Nutr. 2018, 4, 74. [CrossRef] [PubMed]

746. Dumont, B.; Groot, J.C.J.; Tichit, M. Review: Make ruminants green again-How can sustainable intensification and agroecology converge for a better future? Animal 2018, 12, s210-s219. [CrossRef] [PubMed]

747. Eakin, H.; Sweeney, S.; Lerner, A.M.; Appendini, K.; Perales, H.; Steigerwald, D.G.; Dewes, C.F.; Davenport, F.; Bausch, J.C. Agricultural change and resilience: Agricultural policy, climate trends and market integration in the Mexican maize system. Anthropocene 2018, 23, 43-52. [CrossRef]

748. Eckstein, J.; Young, A.M. wastED rhetoric. Commun. Crit. Stud. 2018, 15, 274-291. [CrossRef]

749. El Bilali, H. Relation between innovation and sustainability in the agro-food system. Ital. J. Food Sci. 2018, 30, 200-225. [CrossRef] 
750. Fang, X.; Huang, H.; Leung, P. Competitiveness of local food: An empirical analysis of the tomato market dynamics. Int. Food Agribus. Manag. Rev. 2018, 21, 89-100. [CrossRef]

751. Figueroa-Helland, L.; Thomas, C.; Aguilera, A.P. Decolonizing Food Systems: Food Sovereignty, Indigenous Revitalization, and Agroecology as Counter-Hegemonic Movements. Perspect. Glob. Dev. Technol. 2018, 17, 173-201. [CrossRef]

752. Fink, L.; Ploeger, A.; Strassner, C. Participative Processes as a Chance for Developing Ideas to Bridge the Intention-Behavior Gap Concerning Sustainable Diets. Sustainability 2018, 10, 4434. [CrossRef]

753. Finlayson, C. Perfect food: Perspectives on consumer perceptions of fresh produce quality. Fenn. Int. J. Geogr. 2018, 196, 168-186. [CrossRef]

754. Flores, H.; Villalobos, J.R. A modeling framework for the strategic design of local fresh-food systems. Agric. Syst. 2018, 161, 1-15. [CrossRef]

755. Forssell, S.; Lankoski, L. Shaping norms. A convention theoretical examination of alternative food retailers as food sustainability transition actors. J. Rural Stud. 2018, 63, 46-56. [CrossRef]

756. Freudenberg, N.; Willingham, C.; Cohen, N. The Role of Metrics in Food Policy: Lessons from a Decade of Experience in New York City. J. Agric. Food Syst. Community Dev. 2018, 8, 191-209. [CrossRef]

757. Fridman, D.; Kissinger, M. An integrated biophysical and ecosystem approach as a base for ecosystem services analysis across regions. Ecosyst. Serv. 2018, 31, 242-254. [CrossRef]

758. Furman, C.A.; Papavasiliou, F. Scale and affect in the local food movement. Food Cult. Soc. 2018, 21, 180-195. [CrossRef]

759. Gallardo-López, F.; Hernández-Chontal, M.; Cisneros-Saguilán, P.; Linares-Gabriel, A. Development of the Concept of Agroecology in Europe: A Review. Sustainability 2018, 10, 1210. [CrossRef]

760. García-Sempere, A.; Hidalgo, M.; Morales, H.; Ferguson, B.G.; Nazar-Beutelspacher, A.; Rosset, P. Urban transition toward food sovereignty. Globalizations 2018, 15, 390-406. [CrossRef]

761. Gilbert, J.; Schindel, A.; Robert, S. Just Transitions in a Public School Food System: The Case of Buffalo, New York. J. Agric. Food Syst. Community Dev. 2018, 95-113. [CrossRef]

762. Gisslevik, E.; Wernersson, I.; Larsson, C. Home Economics Teachers' Perceptions of Facilitating and Inhibiting Factors When Teaching Sustainable Food Consumption. Sustainability 2018, 10, 1463. [CrossRef]

763. Goggins, G. Developing a sustainable food strategy for large organizations: The importance of context in shaping procurement and consumption practices. Bus. Strateg. Environ. 2018, 27, 838-848. [CrossRef]

764. Goralnik, L.; Thorp, L.; Rickborn, A. Food System Field Experience: STEM Identity and Change Agency for Undergraduate Sustainability Learners. J. Exp. Educ. 2018, 41, 312-328. [CrossRef]

765. Grant, M.; Shreck, A.; Buchmann, N. Tackling Food System Challenges through Experiential Education: Criteria for Optimal Course Design. GAIA Ecol. Perspect. Sci. Soc. 2018, 27, 169-175. [CrossRef]

766. Grivins, M.; Tisenkopfs, T.; Tikka, V.; Silvasti, T. Manoeuvring between regulations to achieve locally accepted results: Analysis of school meals in Latvia and Finland. Food Secur. 2018, 10, 1389-1400. [CrossRef]

767. Hanserud, O.S.; Cherubini, F.; Øgaard, A.F.; Müller, D.B.; Brattebø, H. Choice of mineral fertilizer substitution principle strongly influences LCA environmental benefits of nutrient cycling in the agri-food system. Sci. Total Environ. 2018, 615, 219-227. [CrossRef]

768. Hashem, S.; Migliore, G.; Schifani, G.; Schimmenti, E.; Padel, S. Motives for buying local, organic food through English box schemes. Br. Food J. 2018, 120, 1600-1614. [CrossRef]

769. Hebinck, P.; Oostindie, H. Performing food and nutritional security in Europe: Claims, promises and limitations. Food Secur. 2018, 10, 1311-1324. [CrossRef]

770. Henriksson, P.J.G.; Belton, B.; Jahan, K.M.-; Rico, A. Measuring the potential for sustainable intensification of aquaculture in Bangladesh using life cycle assessment. Proc. Natl. Acad. Sci. USA 2018, 115, 2958-2963. [CrossRef]

771. Hernández, P.; Guimarães, M.; Rivera, M.; Silva, E. Assessing Sustainable Food Systems Governance in EU’s Outermost Regions-The Case of the Azores in Portugal. Sustainability 2018, 10, 3057. [CrossRef]

772. Heron, T.; Prado, P.; West, C. Global Value Chains and the Governance of 'Embedded' Food Commodities: The Case of Soy. Glob. Policy 2018, 9, 29-37. [CrossRef]

773. Herrera-Reyes, A.; Carmenado, I.; Martínez-Almela, J. Project-Based Governance Framework for an Agri-Food Cooperative. Sustainability 2018, 10, 1881. [CrossRef]

774. Heuschkel, Z.; Hirsch, D.; Terlau, W.; Lorleberg, W. New approaches in securing more sustainable urban food futures: Case from Cologne-Bonn region. Acta Hortic. 2018, 421-426. [CrossRef]

775. Hoolohan, C.; McLachlan, C.; Mander, S. Food related routines and energy policy: A focus group study examining potential for change in the United Kingdom. Energy Res. Soc. Sci. 2018, 39, 93-102. [CrossRef]

776. Huambachano, M. Enacting food sovereignty in Aotearoa New Zealand and Peru: Revitalizing Indigenous knowledge, food practices and ecological philosophies. Agroecol. Sustain. Food Syst. 2018, 42, 1003-1028. [CrossRef]

777. Hubeau, M.; Marchand, F.; Coteur, I.; Debruyne, L.; Van Huylenbroeck, G. A reflexive assessment of a regional initiative in the agri-food system to test whether and how it meets the premises of transdisciplinary research. Sustain. Sci. 2018, 13, 1137-1154. [CrossRef]

778. Ilieva, R.; Hernandez, A. Scaling-Up Sustainable Development Initiatives: A Comparative Case Study of Agri-Food System Innovations in Brazil, New York, and Senegal. Sustainability 2018, 10, 4057. [CrossRef] 
779. Infante-Amate, J.; Aguilera, E.; de Molina, M.G. Energy transition in Agri-food systems. Structural change, drivers and policy implications (Spain, 1960-2010). Energy Policy 2018, 122, 570-579. [CrossRef]

780. Ingenbleek, P.T.M.; Zhao, Y. Hutten catering: How to organize innovation for vital consumers in a sustainable food system? Int. Food Agribus. Manag. Rev. 2018, 21, 583-594. [CrossRef]

781. Jacobi, J.; Mukhovi, S.; Llanque, A.; Augstburger, H.; Käser, F.; Pozo, C.; Ngutu Peter, M.; Delgado, J.M.F.; Kiteme, B.P.; Rist, S.; et al. Operationalizing food system resilience: An indicator-based assessment in agroindustrial, smallholder farming, and agroecological contexts in Bolivia and Kenya. Land Use Policy 2018, 79, 433-446. [CrossRef]

782. James, S.W.; Friel, S.; Lawrence, M.A.; Hoek, A.C.; Pearson, D. Inter-sectoral action to support healthy and environmentally sustainable food behaviours: A study of sectoral knowledge, governance and implementation opportunities. Sustain. Sci. 2018, 13, 465-477. [CrossRef]

783. Jayashankar, P.; Van Auken, H.; Ashta, A. What motivates ecopreneurs in the United States to create value? Strateg. Chang. 2018, 27, 509-521. [CrossRef]

784. Jedelhauser, M.; Binder, C.R. The spatial impact of socio-technical transitions-The case of phosphorus recycling as a pilot of the circular economy. J. Clean. Prod. 2018, 197, 856-869. [CrossRef]

785. Jellil, A.; Woolley, E.; Rahimifard, S. Towards integrating production and consumption to reduce consumer food waste in developed countries. Int. J. Sustain. Eng. 2018, 11, 294-306. [CrossRef]

786. Karlsson, J.O.; Carlsson, G.; Lindberg, M.; Sjunnestrand, T.; Röös, E. Designing a future food vision for the Nordics through a participatory modeling approach. Agron. Sustain. Dev. 2018, 38, 59. [CrossRef]

787. Huddart Kennedy, E.; Parkins, J.R.; Johnston, J. Food activists, consumer strategies, and the democratic imagination: Insights from eat-local movements. J. Consum. Cult. 2018, 18, 149-168. [CrossRef]

788. Kumbamu, A. Building sustainable social and solidarity economies: Place-based and network-based strategies of alternative development organizations in India. Community Dev. 2018, 49, 18-33. [CrossRef]

789. Kuokkanen, A.; Nurmi, A.; Mikkilä, M.; Kuisma, M.; Kahiluoto, H.; Linnanen, L. Agency in regime destabilization through the selection environment: The Finnish food system's sustainability transition. Res. Policy 2018, 47, 1513-1522. [CrossRef]

790. Lamalice, A.; Haillot, D.; Lamontagne, M.-A.; Herrmann, T.M.; Gibout, S.; Blangy, S.; Martin, J.-L.; Coxam, V.; Arsenault, J.; Munro, L.; et al. Building food security in the Canadian Arctic through the development of sustainable community greenhouses and gardening. Écoscience 2018, 25, 325-341. [CrossRef]

791. Larimore, S. Cultural Boundaries to Access in Farmers Markets Accepting Supplemental Nutrition Assistance Program (SNAP). Qual. Sociol. 2018, 41, 63-87. [CrossRef]

792. Laso, J.; Hoehn, D.; Margallo, M.; García-Herrero, I.; Batlle-Bayer, L.; Bala, A.; Fullana-i-Palmer, P.; Vázquez-Rowe, I.; Irabien, A.; Aldaco, R. Assessing Energy and Environmental Efficiency of the Spanish Agri-Food System Using the LCA/DEA Methodology. Energies 2018, 11, 3395. [CrossRef]

793. Lawlis, T.; Devine, A.; Upton, P. Vulnerable, single and living in poverty: Women's challenges to accessing food in the Australian Capital Territory. Aust. N. Z. J. Public Health 2018, 42, 541-546. [CrossRef]

794. Le Noë, J.; Garnier, J.; Billen, G. Phosphorus management in cropping systems of the Paris Basin: From farm to regional scale. J. Environ. Manag. 2018, 205, 18-28. [CrossRef]

795. Levkoe, C.; Hammelman, C.; Craven, L.; Dandy, G.; Farbman, J.; Harrison, J.; Mount, P. Building sustainable communities through food hubs: Practitioner and academic perspectives. J. Agric. Food Syst. Community Dev. 2018, 8, 107-122. [CrossRef]

796. Liberatore, L.; Casolani, N.; Murmura, F. What's behind organic certification of extra-virgin olive oil? A response from Italian consumers. J. Food Prod. Mark. 2018, 24, 946-959. [CrossRef]

797. Limuwa, M.; Singini, W.; Storebakken, T. Is fish farming an illusion for Lake Malawi Riparian communities under environmental changes? Sustainability 2018, 10, 1453. [CrossRef]

798. Lindgren, E.; Harris, F.; Dangour, A.D.; Gasparatos, A.; Hiramatsu, M.; Javadi, F.; Loken, B.; Murakami, T.; Scheelbeek, P.; Haines, A. Sustainable food systems-A health perspective. Sustain. Sci. 2018, 13, 1505-1517. [CrossRef] [PubMed]

799. Mantino, F.; Forcina, B. Market, Policies and local governance as drivers of environmental public benefits: The case of the localised processed tomato in Northern Italy. Agriculture 2018, 8, 34. [CrossRef]

800. Maughan, C. 'Food from Nowhere': Food, fuel and the fantastical. Open Libr. Humanit. 2018, 4. [CrossRef]

801. Mehr, J.; Jedelhauser, M.; Binder, C. Transition of the Swiss Phosphorus System towards a Circular Economy-Part 1: Current State and Historical Developments. Sustainability 2018, 10, 1479. [CrossRef]

802. Mittal, A.; Krejci, C.; Craven, T. Logistics best practices for regional food systems: A Review. Sustainability 2018, 10, 168. [CrossRef]

803. Moragues-Faus, A.; Marceau, A. Measuring progress in sustainable food cities: An indicators toolbox for action. Sustainability 2018, 11, 45. [CrossRef]

804. Morawicki, R.O.; Gonzalez, D.J.D. Food Sustainability in the Context of Human Behavior. Yale J. Biol. Med. 2018, 91, 191-196. [PubMed]

805. Moschitz, H.; Landert, J.; Schader, C.; Frick, R. From Urban Agriculture to Urban Food. Nat. Cult. 2018, 13, 113-134. [CrossRef]

806. Muchenje, V.; Mukumbo, F.E.; Njisane, Y.Z. Meat in a sustainable food system. S. Afr. J. Anim. Sci. 2018, 48, 818. [CrossRef]

807. Mulligan, K.; Archbold, J.; Baker, L.; Elton, S.; Cole, D. Toronto Municipal Staff and Policy-makers' Views on Urban Agriculture and Health: A Qualitative Study. J. Agric. Food Syst. Community Dev. 2018, 133-156. [CrossRef] 
808. Narayan, B.; Jayakumar, J. Urban metabolism and food security: Emergy as a metrics link connecting the food security with the urban spatial aspects for enhanced livability and sustainability. In Proceedings of the 5th Biennial International Conference on Emerging Trends in Engineering, Science and Technology (ICETEST), Thrissur, India, 18-20 January 2018; Vanchipura, R., Jiji, K., Eds.; CRC Press-Taylor \& Francis Group: Boca Raton, FL, USA, 2018; pp. 995-1000.

809. Nogeire-McRae, T.; Ryan, E.P.; Jablonski, B.B.R.; Carolan, M.; Arathi, H.S.; Brown, C.S.; Saki, H.H.; McKeen, S.; Lapansky, E.; Schipanski, M.E. The Role of Urban Agriculture in a Secure, Healthy, and Sustainable Food System. Bioscience 2018, 68, 748-759. [CrossRef]

810. Olsson, E.G.A. Urban food systems as vehicles for sustainability transitions. Bull. Geogr. Socio-economic Ser. 2018, 40, 133-144. [CrossRef]

811. Osendarp, S.J.M.; Martinez, H.; Garrett, G.S.; Neufeld, L.M.; De-Regil, L.M.; Vossenaar, M.; Darnton-Hill, I. Large-Scale Food Fortification and Biofortification in Low- and Middle-Income Countries: A Review of Programs, Trends, Challenges, and Evidence Gaps. Food Nutr. Bull. 2018, 39, 315-331. [CrossRef]

812. Paciarotti, C.; Torregiani, F. Short food supply chain between micro/small farms and restaurants. Br. Food J. 2018, $120,1722-1734$. [CrossRef]

813. Pereira, Á.; Villanueva-Rey, P.; Vence, X.; Moreira, M.T.; Feijóo, G. Fresh milk supply through vending machines: Consumption patterns and associated environmental impacts. Sustain. Prod. Consum. 2018, 15, 119-130. [CrossRef]

814. Pérez-Consuegra, N.; Mirabal, L.; Jiménez, L.C. The role of biological control in the sustainability of the Cuban agri-food system. Elem. Sci. Anthr. 2018, 6, 79. [CrossRef]

815. Pitt, H.; Jones, M.; Weitkamp, E. Every City a Food Growing City? What Food Growing Schools London Reveals about City Strategies for Food System Sustainability. Sustainability 2018, 10, 2924. [CrossRef]

816. Plumecocq, G.; Debril, T.; Duru, M.; Magrini, M.-B.; Sarthou, J.P.; Therond, O. The plurality of values in sustainable agriculture models: Diverse lock-in and coevolution patterns. Ecol. Soc. 2018, 23, art21. [CrossRef]

817. Pothukuchi, K. Vacant land disposition for agriculture in Cleveland, Ohio: Is community development a mixed blessing? J. Urban Aff. 2018, 40, 657-678. [CrossRef]

818. Pothukuchi, K.; Arrowsmith, M.; Lyon, N. Hydraulic Fracturing. J. Plan. Lit. 2018, 33, 155-170. [CrossRef]

819. Pulker, C.E.; Trapp, G.S.A.; Scott, J.A.; Pollard, C.M. Global supermarkets' corporate social responsibility commitments to public health: A content analysis. Global. Health 2018, 14, 121. [CrossRef] [PubMed]

820. Ritchie, H.; Reay, D.; Higgins, P. Sustainable food security in India-Domestic production and macronutrient availability. PLoS ONE 2018, 13, e0193766. [CrossRef] [PubMed]

821. Ritchie, H.; Reay, D.S.; Higgins, P. Beyond Calories: A Holistic Assessment of the Global Food System. Front. Sustain. Food Syst. 2018, 2. [CrossRef]

822. Rivera-Ferre, M.G. The resignification process of Agroecology: Competing narratives from governments, civil society and intergovernmental organizations. Agroecol. Sustain. Food Syst. 2018, 42, 666-685. [CrossRef]

823. Robinson, G.M. New frontiers in agricultural geography: Transformations, food security, land grabs and climate change. Boletín la Asoc. Geógrafos Españoles 2018, 78, 1-48. [CrossRef]

824. Rohmer, S.U.K.; Gerdessen, J.C.; Claassen, G.D.H.; Bloemhof, J.M.; van 't Veer, P. A nutritional comparison and production perspective: Reducing the environmental footprint of the future. J. Clean. Prod. 2018, 196, 1407-1417. [CrossRef]

825. Ruben, R.; Verhagen, J.; Plaisier, C. The Challenge of Food Systems Research: What Difference Does It Make? Sustainability 2018, 11, 171. [CrossRef]

826. Rut, M.; Davies, A.R. Transitioning without confrontation? Shared food growing niches and sustainable food transitions in Singapore. Geoforum 2018, 96, 278-288. [CrossRef]

827. Rutten, M.; Achterbosch, T.J.; de Boer, I.J.M.; Cuaresma, J.C.; Geleijnse, J.M.; Havlík, P.; Heckelei, T.; Ingram, J.; Leip, A.; Marette, S.; et al. Metrics, models and foresight for European sustainable food and nutrition security: The vision of the SUSFANS project. Agric. Syst. 2018, 163, 45-57. [CrossRef]

828. Salavisa, I.; de Fatima Ferreiro, M. Sustainable Food systems: How Important are Bottom-Up Innovative Experiments? In Proceedings of the 13th European Conference on Innovation and Entrepreneurship (ECIE), Aveiro, Portugal, 20-21 September 2018; Costa, C., Oliveira, M.A.-Y., Amorim, M., Eds.; ACAD Conferences Ltd.: Reading, UK, 2018 ; pp. 701-708.

829. Schmidt, K.; Matthies, E. Where to start fighting the food waste problem? Identifying most promising entry points for intervention programs to reduce household food waste and overconsumption of food. Resour. Conserv. Recycl. 2018, 139, 1-14. [CrossRef]

830. Scott, C. Sustainably Sourced Junk Food? Big Food and the Challenge of Sustainable Diets. Glob. Environ. Polit. 2018, 18, 93-113. [CrossRef]

831. Sebbane, M.; Costa, S. Food leftovers in workplace cafeterias: An exploratory analysis of stated behavior and actual behavior. Resour. Conserv. Recycl. 2018, 136, 88-94. [CrossRef]

832. Seconda, L.; Baudry, J.; Allès, B.; Soler, L.-G.; Hercberg, S.; Langevin, B.; Pointereau, P.; Lairon, D.; Kesse-Guyot, E. Identification of sustainable dietary patterns by a multicriteria approach in the NutriNet-Santé cohort. J. Clean. Prod. 2018, 196, 1256-1265. [CrossRef]

833. Shepon, A.; Henriksson, P.J.G.; Wu, T. Conceptualizing a Sustainable Food System in an Automated World: Toward a "Eudaimonian" Future. Front. Nutr. 2018, 5, 104. [CrossRef] 
834. Slater, J.; Falkenberg, T.; Rutherford, J.; Colatruglio, S. Food literacy competencies: A conceptual framework for youth transitioning to adulthood. Int. J. Consum. Stud. 2018, 42, 547-556. [CrossRef]

835. Sušnik, J. Data-driven quantification of the global water-energy-food system. Resour. Conserv. Recycl. 2018, 133, 179-190. [CrossRef]

836. Taylor, M. Climate-smart agriculture: What is it good for? J. Peasant Stud. 2018, 45, 89-107. [CrossRef]

837. Teneva, L.T.; Schemmel, E.; Kittinger, J.N. State of the plate: Assessing present and future contribution of fisheries and aquaculture to Hawai'i's food security. Mar. Policy 2018, 94, 28-38. [CrossRef]

838. Thompson, P.B. Four sociotechnical imaginaries for future food systems. In Professionals in Food Chains; Springer, S., Grimm, H., Eds.; Wageningen Academic Publishers: Wageningen, The Netherlands, 2018; pp. 187-191.

839. Tribaldos, T.; Jacobi, J.A.; Rist, S. Linking sustainable diets to the concept of food system sustainability. Futur. Food J. Food Agric. Soc. 2018, 6, 71-84.

840. Vaarst, M.; Escudero, A.G.; Chappell, M.J.; Brinkley, C.; Nijbroek, R.; Arraes, N.A.M.; Andreasen, L.; Gattinger, A.; De Almeida, G.F.; Bossio, D.; et al. Exploring the concept of agroecological food systems in a city-region context. Agroecol. Sustain. Food Syst. 2018, 42, 686-711. [CrossRef]

841. Valley, W.; Wittman, H.; Jordan, N.; Ahmed, S.; Galt, R. An emerging signature pedagogy for sustainable food systems education. Renew. Agric. Food Syst. 2018, 33, 467-480. [CrossRef]

842. Van Dooren, C.; Aiking, H.; Vellinga, P. In search of indicators to assess the environmental impact of diets. Int. J. Life Cycle Assess. 2018, 23, 1297-1314. [CrossRef]

843. Van Kernebeek, H.R.J.; Oosting, S.J.; van Ittersum, M.K.; Ripoll-Bosch, R.; de Boer, I.J.M. Closing the phosphorus cycle in a food system: Insights from a modelling exercise. Animal 2018, 12, 1755-1765. [CrossRef]

844. Vandermeer, J.; Aga, A.; Allgeier, J.; Badgley, C.; Baucom, R.; Blesh, J.; Shapiro, L.F.; Jones, A.D.; Hoey, L.; Jain, M.; et al. Feeding Prometheus: An Interdisciplinary Approach for Solving the Global Food Crisis. Front. Sustain. Food Syst. 2018, 2, 39. [CrossRef]

845. Vasa, L.; Angeloska, A.; Trendov, N.M. Comparative analysis of circular agriculture development in selected Western Balkan countries based on sustainable performance indicators. Econ. Ann. 2018, 168, 44-47. [CrossRef]

846. Verger, E.O.; Perignon, M.; El Ati, J.; Darmon, N.; Dop, M.-C.; Drogué, S.; Dury, S.; Gaillard, C.; Sinfort, C.; Amiot, M.-J A “Fork-to-Farm" Multi-Scale Approach to Promote Sustainable Food Systems for Nutrition and Health: A Perspective for the Mediterranean Region. Front. Nutr. 2018, 5, 30. [CrossRef] [PubMed]

847. Vroegindewey, R.; Hodbod, J. Resilience of Agricultural Value Chains in Developing Country Contexts: A Framework and Assessment Approach. Sustainability 2018, 10, 916. [CrossRef]

848. Waterlander, W.E.; Ni Mhurchu, C.; Eyles, H.; Vandevijvere, S.; Cleghorn, C.; Scarborough, P.; Swinburn, B.; Seidell, J. Food Futures: Developing effective food systems interventions to improve public health nutrition. Agric. Syst. 2018, 160, 124-131. [CrossRef]

849. Wegener, J.; Fong, D.; Rocha, C. Education, practical training and professional development for public health practitioners: A scoping review of the literature and insights for sustainable food system capacity-building. Public Health Nutr. 2018, 21, 1771-1780. [CrossRef] [PubMed]

850. Withers, P.; Doody, D.; Sylvester-Bradley, R. Achieving Sustainable Phosphorus Use in Food Systems through Circularisation. Sustainability 2018, 10, 1804. [CrossRef]

851. Zheng, Q.; Wang, H.; Lu, Y. Consumer Purchase Intentions for Sustainable Wild Salmon in the Chinese Market and Implications for Agribusiness Decisions. Sustainability 2018, 10, 1377. [CrossRef]

852. Zimmerman, R.; Zhu, Q.; Dimitri, C. A network framework for dynamic models of urban food, energy and water systems (FEWS). Environ. Prog. Sustain. Energy 2018, 37, 122-131. [CrossRef]

853. Zvaigzne, A.; Krivašonoka, I.; Kotāne, I. Factors Influencing Local Food Sales Through Green Public Procurement in Rezekne Municipality. In Reliability and Statistics in Transportation and Communication; Kabashkin, I., Yatskiv, I., Prentkovskis, O., Eds.; Springer: Dordrecht, The Netherlands, 2018; pp. 327-337.

854. Adeyeye, S.A.O. The role of food processing and appropriate storage technologies in ensuring food security and food availability in Africa. Nutr. Food Sci. 2017, 47, 122-139. [CrossRef]

855. Ahmed, S.; Sclafani, A.; Aquino, E.; Kala, S.; Barias, L.; Eeg, J. Building student capacity to lead sustainability transitions in the food system through farm-based authentic research modules in sustainability sciences (FARMS). Elem. Sci. Anthr. 2017, 5, 46. [CrossRef]

856. Alexander, P.; Brown, C.; Arneth, A.; Dias, C.; Finnigan, J.; Moran, D.; Rounsevell, M.D.A. Could consumption of insects, cultured meat or imitation meat reduce global agricultural land use? Glob. Food Sec. 2017, 15, 22-32. [CrossRef]

857. Alexander, P.; Brown, C.; Arneth, A.; Finnigan, J.; Moran, D.; Rounsevell, M.D.A. Losses, inefficiencies and waste in the global food system. Agric. Syst. 2017, 153, 190-200. [CrossRef]

858. Alrøe, H.; Sautier, M.; Legun, K.; Whitehead, J.; Noe, E.; Moller, H.; Manhire, J. Performance versus Values in Sustainability Transformation of Food Systems. Sustainability 2017, 9, 332. [CrossRef]

859. Arcari, P. Normalised, human-centric discourses of meat and animals in climate change, sustainability and food security literature. Agric. Human Values 2017, 34, 69-86. [CrossRef]

860. Barlett, P.F. Campus Alternative Food Projects and Food Service Realities: Alternative Strategies. Hum. Organ. 2017, 76, 189-203. [CrossRef] 
861. Sanderson Bellamy, A.; Ioris, A. Addressing the Knowledge Gaps in Agroecology and Identifying Guiding Principles for Transforming Conventional Agri-Food Systems. Sustainability 2017, 9, 330. [CrossRef]

862. Bellante, L. Building the local food movement in Chiapas, Mexico: Rationales, benefits, and limitations. Agric. Human Values 2017, 34, 119-134. [CrossRef]

863. Benis, K.; Ferrão, P. Potential mitigation of the environmental impacts of food systems through urban and peri-urban agriculture (UPA)—A life cycle assessment approach. J. Clean. Prod. 2017, 140, 784-795. [CrossRef]

864. Berno, T. Social enterprise, sustainability and community in post-earthquake Christchurch. J. Enterprising Communities People Places Glob. Econ. 2017, 11, 149-165. [CrossRef]

865. Bogadottir, R.; Olsen, E.S. Making degrowth locally meaningful: The case of the Faroese grindadrap. J. Polit. Ecol. 2017, 24, 504-518. [CrossRef]

866. Boyer, D.; Ramaswami, A. What is the contribution of city-scale actions to the overall food system's environmental impacts?: Assessing water, greenhouse gas, and land impacts of future urban food scenarios. Environ. Sci. Technol. 2017, 51, 12035-12045. [CrossRef]

867. Brimblecombe, J.; Bailie, R.; van den Boogaard, C.; Wood, B.; Liberato, S.; Ferguson, M.; Coveney, J.; Jaenke, R.; Ritchie, J. Feasibility of a novel participatory multi-sector continuous improvement approach to enhance food security in remote Indigenous Australian communities. SSM Popul. Health 2017, 3, 566-576. [CrossRef]

868. Brzezina, N.; Biely, K.; Helfgott, A.; Kopainsky, B.; Vervoort, J.; Mathijs, E. Development of organic farming in europe at the crossroads: Looking for the way forward through System Archetypes Lenses. Sustainability 2017, 9, 821. [CrossRef]

869. Cardoso, A.S.; Domingos, T.; de Magalhães, M.R.; de Melo-Abreu, J.; Palma, J. Mapping the lisbon potential foodshed in Ribatejo E Oeste: A suitability and yield model for assessing the potential for localized food production. Sustainability 2017, 9, 2003. [CrossRef]

870. Carlsson, L.; Callaghan, E.; Morley, A.; Broman, G. Food system sustainability across scales: A proposed local-to-global approach to community planning and assessment. Sustainability 2017, 9, 1061. [CrossRef]

871. Cuy Castellanos, D.; Jones, J.C.; Christaldi, J.; Liutkus, K.A. Perspectives on the development of a local food system: The case of Dayton, Ohio. Agroecol. Sustain. Food Syst. 2017, 41, 186-203. [CrossRef]

872. Charles, K. The Role and Impact of the Food Industry in the Growth and Development of the Food Bank Movement. Bus. Peace Sustain. Dev. 2017, 19-34. [CrossRef]

873. Clapp, J. The trade-ification of the food sustainability agenda. J. Peasant Stud. 2017, 44, 335-353. [CrossRef]

874. Conrad, Z.; Tichenor, N.E.; Peters, C.J.; Griffin, T.S. Regional self-reliance for livestock feed, meat, dairy and eggs in the Northeast USA. Renew. Agric. Food Syst. 2017, 32, 145-156. [CrossRef]

875. Coppola, A.; Ianuario, S. Environmental and social sustainability in Producer Organizations' strategies. Br. Food J. 2017, 119, 1732-1747. [CrossRef]

876. Deller, S.C.; Lamie, D.; Stickel, M. Local foods systems and community economic development. Community Dev. 2017, 48, 612-638. [CrossRef]

877. Derqui, B.; Fernandez, V. The opportunity of tracking food waste in school canteens: Guidelines for self-assessment. Waste Manag. 2017, 69, 431-444. [CrossRef]

878. Eakin, H.; Connors, J.P.; Wharton, C.; Bertmann, F.; Xiong, A.; Stoltzfus, J. Identifying attributes of food system sustainability: Emerging themes and consensus. Agric. Human Values 2017, 34, 757-773. [CrossRef]

879. Eakin, H.; Rueda, X.; Mahanti, A. Transforming governance in telecoupled food systems. Ecol. Soc. 2017, 22, art32. [CrossRef]

880. Ernsteins, R.; Lontone-Ievina, A.; Zilniece, I.; Zvirbule, L. Regional and Local Sustainable Food systems Governance: Collaboration and Communication. In Proceedings of the 22nd International Scientific Conference on Economic and Social Development (ESD)—The Legal Challenges of Modern World, Split, Croatia, 29-30 June 2017; Radic, Z., Roncevic, A., Yongqiang, L., Eds.; Varazdin Development \& Entrepreneurship Agency: Varazdin, Croatia, 2017; pp. 768-778.

881. Fagioli, F.F.; Rocchi, L.; Paolotti, L.; Słowiński, R.; Boggia, A. From the farm to the agri-food system: A multiple criteria framework to evaluate extended multi-functional value. Ecol. Indic. 2017, 79, 91-102. [CrossRef]

882. Farmery, A.K.; Gardner, C.; Jennings, S.; Green, B.S.; Watson, R.A. Assessing the inclusion of seafood in the sustainable diet literature. Fish Fish. 2017, 18, 607-618. [CrossRef]

883. Fassio, F. Food events as complex cultural systems for territorial reconnection: The case study of Terra Madre Salone Del Gusto. Agroecol. Sustain. Food Syst. 2017, 41, 907-920. [CrossRef]

884. Fiisabilillah, D.F.; Maulana, A. Feeding the Megacity: Challenges to Achieve Food Security in Jakarta. J. Perenc. Wil. Dan Kota 2017, 27, 208. [CrossRef]

885. Finley, J.W.; Dimick, D.; Marshall, E.; Nelson, G.C.; Mein, J.R.; Gustafson, D.I. Nutritional Sustainability: Aligning Priorities in Nutrition and Public Health with Agricultural Production. Adv. Nutr. 2017, 8, 780-788. [CrossRef]

886. Forssell, S.; Lankoski, L. Navigating the tensions and agreements in alternative food and sustainability: A convention theoretical perspective on alternative food retail. Agric. Human Values 2017, 34, 513-527. [CrossRef]

887. Francis, C.A.; Jensen, E.S.; Lieblein, G.; Breland, T.A. Agroecologist Education for Sustainable Development of Farming and Food Systems. Agron. J. 2017, 109, 23-32. [CrossRef] 
888. Galli, F.; Venturi, F.; Bartolini, F.; Gava, O.; Zinnai, A.; Chiara, S.; Andrich, G.; Brunori, G. Shaping food systems towards improved nutrition: A case study on Tuscan Bread Protected Designation of Origin. Int. Food Agribus. Manag. Rev. 2017, 20, 533-552. [CrossRef]

889. Gardner, C.D.; Hauser, M.E. Food revolution. Am. J. Lifestyle Med. 2017, 11, 387-396. [CrossRef]

890. Giuggioli, N.; Girgenti, V.; Peano, C. Qualitative performance and consumer acceptability of starch films for the blueberry modified atmosphere packaging storage. Polish J. Food Nutr. Sci. 2017, 67, 129-136. [CrossRef]

891. González de Molina, M.; Guzmán, G.I. On the Andalusian origins of agroecology in Spain and its contribution to shaping agroecological thought. Agroecol. Sustain. Food Syst. 2017, 41, 256-275. [CrossRef]

892. Granvik, M.; Joosse, S.; Hunt, A.; Hallberg, I. Confusion and Misunderstanding-Interpretations and Definitions of local food. Sustainability 2017, 9, 1981. [CrossRef]

893. Hadjikakou, M. Trimming the excess: Environmental impacts of discretionary food consumption in Australia. Ecol. Econ. 2017, 131, 119-128. [CrossRef]

894. Hallström, E.; Gee, Q.; Scarborough, P.; Cleveland, D.A. A healthier US diet could reduce greenhouse gas emissions from both the food and health care systems. Clim. Change 2017, 142, 199-212. [CrossRef]

895. Heidelberger, L.; Smith, C.; Robinson-O'Brien, R.; Earthman, C.; Robien, K. Registered Dietitian Nutritionists' perspectives on integrating food and water system issues into professional practice. J. Acad. Nutr. Diet. 2017, 117, 271-277. [CrossRef]

896. Hessle, A.; Bertilsson, J.; Stenberg, B.; Kumm, K.-I.; Sonesson, U. Combining environmentally and economically sustainable dairy and beef production in Sweden. Agric. Syst. 2017, 156, 105-114. [CrossRef]

897. Horton, P.; Banwart, S.A.; Brockington, D.; Brown, G.W.; Bruce, R.; Cameron, D.; Holdsworth, M.; Lenny Koh, S.C.; Ton, J.; Jackson, P. An agenda for integrated system-wide interdisciplinary agri-food research. Food Secur. 2017, 9, 195-210. [CrossRef]

898. Hubeau, M.; Marchand, F.; Van Huylenbroeck, G. Sustainability Experiments in the agri-food system: Uncovering the factors of new governance and collaboration success. Sustainability 2017, 9, 1027. [CrossRef]

899. Islam, M. Sustainability through the Lens of Environmental Sociology: An introduction. Sustainability 2017, 9, 474. [CrossRef]

900. Knickel, K.; Ashkenazy, A.; Chebach, T.C.; Parrot, N. Agricultural modernization and sustainable agriculture: Contradictions and complementarities. Int. J. Agric. Sustain. 2017, 15, 575-592. [CrossRef]

901. Koniordos, M.; Matvienko-Bilyaeva, G.; Strapchuk, S. Strategic scenario of an open source of sustainable development for the food system. Econ. Ann. 2017, 165, 56-59. [CrossRef]

902. Kotir, J.H.; Brown, G.; Marshall, N.; Johnstone, R. Drivers of Change and Sustainability in linked social-ecological systems: An analysis in the Volta River Basin of Ghana, West Africa. Soc. Nat. Resour. 2017, 30, 1229-1245. [CrossRef]

903. Kuhmonen, T. Exposing the attractors of evolving complex adaptive systems by utilising futures images: Milestones of the food sustainability journey. Technol. Forecast. Soc. Change 2017, 114, 214-225. [CrossRef]

904. Laforge, J.M.L.; Anderson, C.R.; McLachlan, S.M. Governments, grassroots, and the struggle for local food systems: Containing, coopting, contesting and collaborating. Agric. Human Values 2017, 34, 663-681. [CrossRef]

905. Landert, J.; Schader, C.; Moschitz, H.; Stolze, M. A Holistic Sustainability Assessment Method for Urban Food System Governance. Sustainability 2017, 9, 490. [CrossRef]

906. Leventon, J.; Laudan, J. Local food sovereignty for global food security? Highlighting interplay challenges. Geoforum 2017, 85, 23-26. [CrossRef]

907. Ligrani, R.; Niewolny, K. Community food work as critical practice: A faith-based perspective through narratives. J. Agric. Food Syst. Community Dev. 2017, 7, 61-77. [CrossRef]

908. Lozano-Cabedo, C.; Gómez-Benito, C. A Theoretical model of food citizenship for the analysis of social praxis. J. Agric. Environ. Ethics 2017, 30, 1-22. [CrossRef]

909. Lutz, J.; Smetschka, B.; Grima, N. Farmer cooperation as a means for creating local food systems-Potentials and challenges. Sustainability 2017, 9, 925. [CrossRef]

910. McInnes, A.; Fraser, E.; Gedalof, Z.; Silver, J. A quantitative analysis of food movement convergence in four Canadian provinces. Agric. Human Values 2017, 34, 787-804. [CrossRef]

911. Messina, J.; Suepa, T.; Snapp, S.; Olson, J.; Nejadhashemi, A.P.; Murray, S.; Moore, N.; Frake, A.; Fan, P.; Adhikari, U. Food system resilience and sustainability in Cambodia. Int. J. Appl. Geospatial Res. 2017, 8, 53-75. [CrossRef]

912. Meybeck, A.; Gitz, V. Sustainable diets within sustainable food systems. Proc. Nutr. Soc. 2017, 76, 1-11. [CrossRef] [PubMed]

913. Meynard, J.-M.; Jeuffroy, M.-H.; Le Bail, M.; Lefèvre, A.; Magrini, M.-B.; Michon, C. Designing coupled innovations for the sustainability transition of agrifood systems. Agric. Syst. 2017, 157, 330-339. [CrossRef]

914. Miles, A.; DeLonge, M.S.; Carlisle, L. Triggering a positive research and policy feedback cycle to support a transition to agroecology and sustainable food systems. Agroecol. Sustain. Food Syst. 2017, 41, 855-879. [CrossRef]

915. Milestad, R.; Kummer, S.; Hirner, P. Does scale matter? Investigating the growth of a local organic box scheme in Austria. J. Rural Stud. 2017, 54, 304-313. [CrossRef]

916. Moragues-Faus, A.; Marsden, T. The political ecology of food: Carving 'spaces of possibility' in a new research agenda. J. Rural Stud. 2017, 55, 275-288. [CrossRef]

917. Moragues-Faus, A.; Sonnino, R.; Marsden, T. Exploring European food system vulnerabilities: Towards integrated food security governance. Environ. Sci. Policy 2017, 75, 184-215. [CrossRef] 
918. Murakami, C.D.; Hendrickson, M.K.; Siegel, M.A. Sociocultural tensions and wicked problems in sustainable agriculture education. Agric. Human Values 2017, 34, 591-606. [CrossRef]

919. Niewolny, K.; Schroeder-Moreno, M.; Mason, G.; McWhirt, A.; Clark, S. Participatory Praxis for Community Food Security Education. J. Agric. Food Syst. Community Dev. 2017, 7, 105-128. [CrossRef]

920. Opitz, I.; Specht, K.; Piorr, A.; Siebert, R.; Zasada, I. Effects of consumer-producer interactions in alternative food networks on consumers' learning about food and agriculture. Morav. Geogr. Rep. 2017, 25, 181-191. [CrossRef]

921. Palacios-Argueello, L.; Morganti, E.; Gonzalez-Feliu, J. Food hub as an efficient alternative to sustainably feed the cities. Rev. Transp. Territ. 2017, 10-33.

922. Paloviita, A. Food security is none of your business? Food supply chain management in support of a sustainable food system. Oper. Supply Chain Manag. Int. J. 2017, 10, 100-108. [CrossRef]

923. Pensado-Leglise, M.; Smolski, A. An eco-egalitarian solution to the capitalist consumer paradox: Integrating short food chains and public market systems. Agriculture 2017, 7, 76. [CrossRef]

924. Peters, C.; Clancy, K.; Hinrichs, C.; Goetz, S. Introduction to the EFSNE project collection of papers. J. Agric. Food Syst. Community Dev. 2017, 7, 159-162. [CrossRef]

925. Polbitsyn, S. Agri-Innovation System Formation in the Northern Regions of Russia: Food Security and Rural Development Implications. In Proceedings of the 12th European Conference on Innovation and Entrepreneurship (ECIE), Paris, France, 21-22 September 2017; Loue, C., Slimane, S.B., Eds.; ACAD Conferences Ltd.: Reading, UK, 2017; pp. 511-519.

926. Popkin, B.M. Relationship between shifts in food system dynamics and acceleration of the global nutrition transition. Nutr. Rev. 2017, 75, 73-82. [CrossRef]

927. Poulsen, M.N. Cultivating citizenship, equity, and social inclusion? Putting civic agriculture into practice through urban farming. Agric. Human Values 2017, 34, 135-148. [CrossRef]

928. Reynolds, C.J. Energy embodied in household cookery: The missing part of a sustainable food system? Part 1: A method to survey and calculate representative recipes. Energy Procedia 2017, 123, 228-234. [CrossRef]

929. Reynolds, C.J. Energy embodied in household cookery: The missing part of a sustainable food system? Part 2: A life cycle assessment of roast beef and Yorkshire pudding. Energy Procedia 2017, 123, 228-234. [CrossRef]

930. Ridoutt, B.G.; Hendrie, G.A.; Noakes, M. Dietary strategies to reduce environmental impact: A critical review of the evidence base. Adv. Nutr. Int. Rev. J. 2017, 8, 933-946. [CrossRef]

931. Röös, E.; Bajželj, B.; Smith, P.; Patel, M.; Little, D.; Garnett, T. Protein futures for Western Europe: Potential land use and climate impacts in 2050. Reg. Environ. Chang. 2017, 17, 367-377. [CrossRef]

932. Ryan-Fogarty, Y.; Becker, G.; Moles, R.; O’Regan, B. Backcasting to identify food waste prevention and mitigation opportunities for infant feeding in maternity services. Waste Manag. 2017, 61, 405-414. [CrossRef] [PubMed]

933. Sanye-Mengual, E.; Oliver-Sola, J.; Ignacio Montero, J.; Rieradevall, J. The role of interdisciplinarity in evaluating the sustainability of urban rooftop agriculture. Futur. Food J. Food Agric. Soc. 2017, 5, 46-58.

934. Seconda, L.; Baudry, J.; Allès, B.; Hamza, O.; Boizot-Szantai, C.; Soler, L.-G.; Galan, P.; Hercberg, S.; Lairon, D.; Kesse-Guyot, E. Assessment of the Sustainability of the Mediterranean Diet Combined with Organic Food Consumption: An Individual Behaviour Approach. Nutrients 2017, 9, 61. [CrossRef]

935. Seekell, D.; Carr, J.; Dell'Angelo, J.; D’Odorico, P.; Fader, M.; Gephart, J.; Kummu, M.; Magliocca, N.; Porkka, M.; Puma, M.; et al. Resilience in the global food system. Environ. Res. Lett. 2017, 12, 025010. [CrossRef]

936. Shankar, B.; Thaiprasert, N.; Gheewala, S.; Smith, R. Policies for healthy and sustainable edible oil consumption: A stakeholder analysis for Thailand. Public Health Nutr. 2017, 20, 1126-1134. [CrossRef]

937. Shilomboleni, H. A sustainability assessment framework for the African green revolution and food sovereignty models in southern Africa. Cogent Food Agric. 2017, 3, 1328150. [CrossRef]

938. Singh-Peterson, L.; Lawrence, G. The changing face of the Mary Valley: Considering the fairness, sustainability and resilience of the agricultural system in a peri-urban setting. Local Environ. 2017, 22, 568-580. [CrossRef]

939. Smith, T.M.; Goodkind, A.L.; Kim, T.; Pelton, R.E.O.; Suh, K.; Schmitt, J. Subnational mobility and consumption-based environmental accounting of US corn in animal protein and ethanol supply chains. Proc. Natl. Acad. Sci. USA 2017, 114, E7891-E7899. [CrossRef]

940. Therond, O.; Duru, M.; Roger-Estrade, J.; Richard, G. A new analytical framework of farming system and agriculture model diversities. A review. Agron. Sustain. Dev. 2017, 37, 21. [CrossRef]

941. Tlusty, M.F.; Thorsen, Ø. Claiming seafood is 'sustainable' risks limiting improvements. Fish Fish. 2017, 18, 340-346. [CrossRef]

942. Van Genuchten, E.J.S.; Mulder, I.J.; Schaaf, N. Strategies for food longevity. In Proceedings of the 2nd Conference on Product Lifetimes and the Environment (PLATE), Delft, The Netherlands, 8-10 November 2017; Bakker, C., Mugge, R., Eds.; IOS Press: Amsterdam, The Netherlands, 2017; pp. 139-143.

943. Van Vliet, N.; Schulte-Herbrüggen, B.; Muhindo, J.; Nebesse, C.; Gambalemoke, S.; Nasi, R. Trends in bushmeat trade in a postconflict forest town: Implications for food security. Ecol. Soc. 2017, 22, art35. [CrossRef]

944. Vdovenko, N.M.; Sokol, L.M. Applied basis of fish policy effect to public food providing. Sci. Bull. Polissia 2017, $202-207$. [CrossRef]

945. Vinnari, M.; Vinnari, E.; Kupsala, S. Sustainability matrix: Interest groups and ethical theories as the basis of decision-making. J. Agric. Environ. Ethics 2017, 30, 349-366. [CrossRef] 
946. Von Oelreich, J.; Milestad, R. Sustainability transformations in the balance: Exploring Swedish initiatives challenging the corporate food regime. Eur. Plan. Stud. 2017, 25, 1129-1146. [CrossRef]

947. Voronin, B.A.; Chupina, I.P.; Sharapova, V.M.; Maslakov, V.V.; Fedorov, M.V.; Cot, E.M.; Mokronosov, A.G. Theoretical aspects of national food security provision issue. Turkish Online J. Des. Art Commun. 2017, 7, 2102-2108. [CrossRef]

948. Allen, T.; Prosperi, P. Modeling sustainable food systems. Environ. Manag. 2016, 57, 956-975. [CrossRef]

949. Alrøe, H.F.; Noe, E. Sustainability assessment and complementarity. Ecol. Soc. 2016, 21, art30. [CrossRef]

950. Alrøe, H.F.; Moller, H.; Læssøe, J.; Noe, E. Opportunities and challenges for multicriteria assessment of food system sustainability. Ecol. Soc. 2016, 21, art38. [CrossRef]

951. Alsaffar, A.A. Sustainable diets: The interaction between food industry, nutrition, health and the environment. Food Sci. Technol. Int. 2016, 22, 102-111. [CrossRef]

952. Baritaux, V.; Houdart, M.; Boutonnet, J.-P.; Chazoule, C.; Corniaux, C.; Fleury, P.; Lacombe, N.; Napoléone, M.; Tourrand, J.-F. Ecological embeddedness in animal food systems (re-)localisation: A comparative analysis of initiatives in France, Morocco and Senegal. J. Rural Stud. 2016, 43, 13-26. [CrossRef]

953. Batat, W.; Manna, V.; Ulusoy, E.; Peter, P.C.; Ulusoy, E.; Vicdan, H.; Hong, S. New paths in researching "alternative" consumption and well-being in marketing: Alternative food consumption/Alternative food consumption: What is "alternative"?/Rethinking "literacy" in the adoption of AFC/Social class dynamics in AFC. Mark. Theory 2016, 16, 561. [CrossRef]

954. Bauermeister, M.R. Social capital and collective identity in the local food movement. Int. J. Agric. Sustain. 2016, 14, 123-141. [CrossRef]

955. Bennetzen, E.H.; Smith, P.; Porter, J.R. Decoupling of greenhouse gas emissions from global agricultural production: 1970-2050. Glob. Chang. Biol. 2016, 22, 763-781. [CrossRef]

956. Berti, G.; Mulligan, C. Competitiveness of Small Farms and Innovative Food Supply Chains: The Role of Food Hubs in Creating Sustainable Regional and Local Food Systems. Sustainability 2016, 8, 616. [CrossRef]

957. Bertmann, F.M.W.; Yaroch, A.L. Role of Breast Milk and Breastfeeding within the Context of a Sustainable, Resilient Food System. J. Hunger Environ. Nutr. 2016, 11, 242-253. [CrossRef]

958. Blay-Palmer, A.; Sonnino, R.; Custot, J. A food politics of the possible? Growing sustainable food systems through networks of knowledge. Agric. Hum. Values 2016, 33, 27-43. [CrossRef]

959. Brooks, S. Inducing food insecurity: Financialisation and development in the post-2015 era. Third World Q. 2016, 37, 768-780. [CrossRef]

960. Brunori, G.; Galli, F.; Barjolle, D.; van Broekhuizen, R.; Colombo, L.; Giampietro, M.; Kirwan, J.; Lang, T.; Mathijs, E.; Maye, D.; et al. Are Local Food Chains More Sustainable than Global Food Chains? Considerations for Assessment. Sustainability 2016, 8, 449. [CrossRef]

961. Brzezina, N.; Kopainsky, B.; Mathijs, E. Can Organic Farming Reduce Vulnerabilities and Enhance the Resilience of the European Food System? A Critical Assessment Using System Dynamics Structural Thinking Tools. Sustainability 2016, 8, 971. [CrossRef]

962. Bui, S.; Cardona, A.; Lamine, C.; Cerf, M. Sustainability transitions: Insights on processes of niche-regime interaction and regime reconfiguration in agri-food systems. J. Rural Stud. 2016, 48, 92-103. [CrossRef]

963. Campbell, L.K. Getting farming on the agenda: Planning, policymaking, and governance practices of urban agriculture in New York City. Urban For. Urban Green. 2016, 19, 295-305. [CrossRef]

964. Carlisle, L. Factors influencing farmer adoption of soil health practices in the United States: A narrative review. Agroecol. Sustain. Food Syst. 2016, 40, 583-613. [CrossRef]

965. Cuy Castellanos, D.; Keller, J.; Majchrzak, E. Exploring the Connection Between Community Food Security Initiatives and Socialcognitive Factors on Dietary Intake. J. Agric. Food Syst. Community Dev. 2016, 7, 21-31. [CrossRef]

966. Cottee, J.; López-Avilés, A.; Behzadian, K.; Bradley, D.; Butler, D.; Downing, C.; Farmani, R.; Ingram, J.; Leach, M.; Pike, A.; et al. The Local Nexus Network: Exploring the Future of Localised Food Systems and Associated Energy and Water Supply; Springer: Cham, Switzerland, 2016; pp. 613-624.

967. Creech, R.R. Sustainable church: Practices that make for a lifetime of service. Rev. Expo. 2016, 113, 285-302. [CrossRef]

968. Davies, F.T.; Bowman, J.E. Horticulture, food security, and the challenge of feeding the world. Acta Hortic. 2016, 1-6. [CrossRef]

969. DeHaan, L.R.; Van Tassel, D.L.; Anderson, J.A.; Asselin, S.R.; Barnes, R.; Baute, G.J.; Cattani, D.J.; Culman, S.W.; Dorn, K.M.; Hulke, B.S.; et al. A pipeline strategy for grain crop domestication. Crop Sci. 2016, 56, 917-930. [CrossRef]

970. DeLonge, M.S.; Miles, A.; Carlisle, L. Investing in the transition to sustainable agriculture. Environ. Sci. Policy 2016, 55, 266-273. [CrossRef]

971. Dixon, J.; Richards, C. On food security and alternative food networks: Understanding and performing food security in the context of urban bias. Agric. Human Values 2016, 33, 191-202. [CrossRef]

972. Doernberg, A.; Zasada, I.; Bruszewska, K.; Skoczowski, B.; Piorr, A. Potentials and limitations of regional organic food supply: A qualitative analysis of two food chain types in the Berlin metropolitan region. Sustainability 2016, 8, 1125. [CrossRef]

973. Dou, Z.; Ferguson, J.D.; Galligan, D.T.; Kelly, A.M.; Finn, S.M.; Giegengack, R. Assessing U.S. food wastage and opportunities for reduction. Glob. Food Sec. 2016, 8, 19-26. [CrossRef]

974. Dyen, M.; Sirieix, L. How does a local initiative contribute to social inclusion and promote sustainable food practices? Focus on the example of social cooking workshops. Int. J. Consum. Stud. 2016, 40, 685-694. [CrossRef] 
975. Eades, D.; Nix, K.; Crane, K. West Virginia Farmers Market Training Network: A Case Study in Connecting Markets and Resources. J. Agric. Food Syst. Community Dev. 2016, 6, 1-12. [CrossRef]

976. Epting, S. Participatory Budgeting and Vertical Agriculture: A Thought Experiment in Food System Reform. J. Agric. Environ. Ethics 2016, 29, 737-748. [CrossRef]

977. Fabinyi, M.; Liu, N. The Social Context of the Chinese Food System: An ethnographic study of the beijing seafood market. Sustainability 2016, 8, 244. [CrossRef]

978. Fan, S.; Brzeska, J. Sustainable food security and nutrition: Demystifying conventional beliefs. Glob. Food Sec. 2016, 11, 11-16. [CrossRef]

979. Ferguson, H. More than something to hold the plants up: Soil as a non-human ally in the struggle for food justice. Local Environ. 2016, 21, 956-968. [CrossRef]

980. Fontoura, Y.; Bharucha, Z.P.; Bohm, S. A Transnational agri-food system for whom? The struggle for hegemony at RIO+20. Rev. Adm. Empres. 2016, 56, 424-437. [CrossRef]

981. Fry, J.P.; Love, D.C.; MacDonald, G.K.; West, P.C.; Engstrom, P.M.; Nachman, K.E.; Lawrence, R.S. Environmental health impacts of feeding crops to farmed fish. Environ. Int. 2016, 91, 201-214. [CrossRef]

982. Galli, F.; Bartolini, F.; Brunori, G. Handling diversity of visions and priorities in food chain sustainability assessment. Sustainability 2016, 8, 305. [CrossRef]

983. Gasperi, D.; Pennisi, G.; Rizzati, N.; Magrefi, F.; Bazzocchi, G.; Mezzacapo, U.; Centrone Stefani, M.; Sanyé-Mengual, E.; Orsini, F.; Gianquinto, G. Towards regenerated and productive vacant areas through urban horticulture: Lessons from Bologna, Italy. Sustainability 2016, 8, 1347. [CrossRef]

984. Gillon, S. Flexible for whom? Flex crops, crises, fixes and the politics of exchanging use values in US corn production. J. Peasant Stud. 2016, 43, 117-139. [CrossRef]

985. Gjerris, M.; Gamborg, C.; Saxe, H. What to Buy? On the complexity of being a critical consumer. J. Agric. Environ. Ethics 2016, 29, 81-102. [CrossRef]

986. Goggins, G.; Rau, H. Beyond calorie counting: Assessing the sustainability of food provided for public consumption. J. Clean. Prod. 2016, 112, 257-266. [CrossRef]

987. Gonçalves, A.; Goufo, P.; Barros, A.; Domínguez-Perles, R.; Trindade, H.; Rosa, E.A.S.; Ferreira, L.; Rodrigues, M. Cowpea (Vigna unguiculata L. Walp), a renewed multipurpose crop for a more sustainable agri-food system: Nutritional advantages and constraints. J. Sci. Food Agric. 2016, 96, 2941-2951. [CrossRef]

988. Grigsby, C.; Hellwinckel, C. Locational Advantage and the Impact of Scale: Comparing Local and Conventional Fruit and Vegetable Transportation Efficiencies. J. Agric. Food Syst. Community Dev. 2016, 121-140. [CrossRef]

989. Gustafson, D.; Gutman, A.; Leet, W.; Drewnowski, A.; Fanzo, J.; Ingram, J. Seven food system metrics of sustainable nutrition security. Sustainability 2016, 8, 196. [CrossRef]

990. Harris, G.; Nixon, D.; Newman, L.; Mullinix, K. Delineating the Southwest British Columbia Bioregion for Food System Design and Planning: A Practical Approach. J. Agric. Food Syst. Community Dev. 2016, 6, 71-86. [CrossRef]

991. Hatt, S.; Artu, S.; Bredart, D.; Lassois, L.; Francis, F.; Haubruge, E.; Garre, S.; Stassart, P.M.; Dufrene, M.; Monty, A.; et al. Towards sustainable food systems: The concept of agroecology and how it questions current research practices. A review. Biotechnol. Agron. Soc. Environ. 2016, 20, 215-224.

992. Heard, B.R.; Miller, S.A. Critical Research Needed to Examine the Environmental Impacts of Expanded Refrigeration on the Food System. Environ. Sci. Technol. 2016, 50, 12060-12071. [CrossRef]

993. Himanen, S.J.; Rikkonen, P.; Kahiluoto, H. Codesigning a resilient food system. Ecol. Soc. 2016, 21, art41. [CrossRef]

994. Hisschemoller, M. Cultivating the glocal garden. Chall. Sustain. 2016, 4, 28-38. [CrossRef]

995. Hobart, H.J. 'Local': Contextualizing Hawai'i's Foodways. Food Cult. Soc. 2016, 19, 427-435. [CrossRef]

996. Hoolohan, C.; McLachlan, C.; Mander, S. Trends and drivers of end-use energy demand and the implications for managing energy in food supply chains: Synthesising insights from the social sciences. Sustain. Prod. Consum. 2016, 8, 1-17. [CrossRef]

997. Horton, P.; Koh, L.; Guang, V.S. An integrated theoretical framework to enhance resource efficiency, sustainability and human health in agri-food systems. J. Clean. Prod. 2016, 120, 164-169. [CrossRef]

998. Hunter, D.; Özkan, I.; Moura de Oliveira Beltrame, D.; Samarasinghe, W.L.G.; Wasike, V.W.; Charrondière, U.R.; Borelli, T.; Sokolow, J. Enabled or Disabled: Is the Environment Right for Using Biodiversity to Improve Nutrition? Front. Nutr. $2016,3,14$. [CrossRef]

999. James, S.W. Beyond 'local' food: How supermarkets and consumer choice affect the economic viability of small-scale family farms in Sydney, Australia. Area 2016, 48, 103-110. [CrossRef]

1000. Johnson, R.; Fraser, E.; Hawkins, R. Overcoming Barriers to Scaling Up Sustainable Alternative Food Systems: A Comparative Case Study of Two Ontario-Based Wholesale Produce Auctions. Sustainability 2016, 8, 328. [CrossRef]

1001. Kline, C.; Barbieri, C.; LaPan, C. The Influence of Agritourism on Niche Meats Loyalty and Purchasing. J. Travel Res. 2016, 55, 643-658. [CrossRef]

1002. Kuokkanen, A.; Mikkilä, M.; Kahiluoto, H.; Kuisma, M.; Linnanen, L. Not only peasants' issue: Stakeholders' perceptions of failures inhibiting system innovation in nutrient economy. Environ. Innov. Soc. Transit. 2016, 20, 75-85. [CrossRef]

1003. Larsson, M.; Milestad, R.; Hahn, T.; von Oelreich, J. The Resilience of a Sustainability Entrepreneur in the Swedish Food System. Sustainability 2016, 8, 550. [CrossRef] 
1004. Longo, P. Food Justice and Sustainability: A New Revolution. Agric. Agric. Sci. Procedia 2016, 8, 31-36. [CrossRef]

1005. Lopes, R. The Mediterranean Diet as a Sustainable Food system. J. Spat. Organ. Dyn. 2016, 4, 281-288.

1006. Lucifero, N. Food Loss and Waste in the EU Law between Sustainability of Well-being and the Implications on Food System and on Environment. Agric. Agric. Sci. Procedia 2016, 8, 282-289. [CrossRef]

1007. Lukito, W.; Wibowo, L.; Wahlqvist, M.L. Developments in clinical food and nutrition science in Indonesia. Asia Pac. J. Clin. Nutr. 2016, 25. [CrossRef]

1008. Manganiello, V. Food System and Territorial Sustainability: The Case Study of Campanian Certified Companies. Agric. Agric. Sci. Procedia 2016, 8, 276-281. [CrossRef]

1009. Martin, G.; Clift, R.; Christie, I. Urban Cultivation and Its Contributions to Sustainability: Nibbles of Food but Oodles of Social Capital. Sustainability 2016, 8, 409. [CrossRef]

1010. McCarthy, B.; Liu, H.-B.; Chen, T. Innovations in the agro-food system. Br. Food J. 2016, 118, 1334-1349. [CrossRef]

1011. McClintock, N.; Mahmoudi, D.; Simpson, M.; Santos, J.P. Socio-spatial differentiation in the Sustainable City: A mixed-methods assessment of residential gardens in metropolitan Portland, Oregon, USA. Landsc. Urban Plan. 2016, 148, 1-16. [CrossRef]

1012. Mench, J.A.; Swanson, J.C.; Arnot, C. The Coalition for Sustainable Egg Supply: A unique public-private partnership for conducting research on the sustainability of animal housing systems using a multistakeholder approach1. J. Anim. Sci. 2016, 94, 1296-1308. [CrossRef]

1013. Meybeck, A.; Gitz, V. Quelle alimentation pour des systèmes alimentaires durables? Cah. Nutr. Diététique 2016, 51, 304-314. [CrossRef]

1014. Moledor, S.; Chalak, A.; Fabian, M.; Talhouk, S. Socioeconomic Dynamics of Vermicomposting Systems in Lebanon. J. Agric. Food Syst. Community Dev. 2016, 6, 145-168. [CrossRef]

1015. Monasterolo, I.; Pasqualino, R.; Janetos, A.; Jones, A. Sustainable and Inclusive Food Systems through the Lenses of a Complex System Thinking Approach-A Bibliometric Review. Agriculture 2016, 6, 44. [CrossRef]

1016. Mourad, M. Recycling, recovering and preventing "food waste": Competing solutions for food systems sustainability in the United States and France. J. Clean. Prod. 2016, 126, 461-477. [CrossRef]

1017. Napawan, N.C.; Burke, E. Productive potential: Evaluating residential urban agriculture. Landsc. Res. 2016, 41, 773-779. [CrossRef]

1018. Nau, F.; Floury, J.; van der Werf, H.; Le Minous, A.-E. Les œufs et les ovoproduits dans l'alimentation des Français. Cah. Nutr. Diététique 2016, 51, 147-156. [CrossRef]

1019. Neset, T.-S.; Cordell, D.; Mohr, S.; VanRiper, F.; White, S. Visualizing Alternative Phosphorus Scenarios for Future Food Security. Front. Nutr. 2016, 3, 47. [CrossRef]

1020. Nhu, T.T.; Schaubroeck, T.; Henriksson, P.J.G.; Bosma, R.; Sorgeloos, P.; Dewulf, J. Environmental impact of non-certified versus certified (ASC) intensive Pangasius aquaculture in Vietnam, a comparison based on a statistically supported LCA. Environ. Pollut. 2016, 219, 156-165. [CrossRef]

1021. O'Kane, G. A moveable feast: Exploring barriers and enablers to food citizenship. Appetite 2016, 105, 674-687. [CrossRef]

1022. O'Keefe, L.; McLachlan, C.; Gough, C.; Mander, S.; Bows-Larkin, A. Consumer responses to a future UK food system. Br. Food J. 2016, 118, 412-428. [CrossRef]

1023. Omoto, R.; Scott, S. Multifunctionality and agrarian transition in alternative agro-food production in the global South: The case of organic shrimp certification in the Mekong Delta, Vietnam. Asia Pac. Viewp. 2016, 57, 121-137. [CrossRef]

1024. Opitz, I.; Berges, R.; Piorr, A.; Krikser, T. Contributing to food security in urban areas: Differences between urban agriculture and peri-urban agriculture in the Global North. Agric. Human Values 2016, 33, 341-358. [CrossRef]

1025. Paloviita, A.; Kortetmäki, T.; Puupponen, A.; Silvasti, T. Vulnerability matrix of the food system: Operationalizing vulnerability and addressing food security. J. Clean. Prod. 2016, 135, 1242-1255. [CrossRef]

1026. Penvern, S.; Kouchner, C.; Ruynat, L.; Simon, S.; Lamine, C. From orchard to agri-food system redesign to reduce pesticide use. IActa Hortic. 2016, 1137, 333-341. [CrossRef]

1027. Peters, C.; Wilkins, J.; Rosas, S.; Pepe, B.; Picardy, J.; Fick, G. Engaging Stakeholders To Refine Models of State-level Food Self-reliance. J. Agric. Food Syst. Community Dev. 2016, 6, 55-69. [CrossRef]

1028. Pitt, H.; Jones, M. Scaling up and out as a pathway for food system transitions. Sustainability 2016, 8, 1025. [CrossRef]

1029. Ponisio, L.; Ehrlich, P. Diversification, Yield and a New Agricultural Revolution: Problems and Prospects. Sustainability 2016, 8, 1118. [CrossRef]

1030. Salgado-Sanchez, R.; Castro-Ramirez, A.E. Mercado El 100: Participative Consumption Experience to Favor the Sustainability of Agriculture and Food systems. Agric. Soc. Desarro. 2016, 13, 105-129.

1031. Sali, G.; Monaco, F.; Mazzocchi, C.; Corsi, S. Exploring Land Use Scenarios in Metropolitan Areas: Food Balance in a Local Agricultural System by Using a Multi-objective Optimization Model. Agric. Agric. Sci. Procedia 2016, 8, 211-221. [CrossRef]

1032. Sjörs, C.; Raposo, S.E.; Sjölander, A.; Bälter, O.; Hedenus, F.; Bälter, K. Diet-related greenhouse gas emissions assessed by a food frequency questionnaire and validated using 7-day weighed food records. Environ. Health 2016, 15, 15. [CrossRef] [PubMed]

1033. Smith, K.; Lawrence, G.; MacMahon, A.; Muller, J.; Brady, M. The resilience of long and short food chains: A case study of flooding in Queensland, Australia. Agric. Human Values 2016, 33, 45-60. [CrossRef] 
1034. Sonesson, U.G.; Lorentzon, K.; Andersson, A.; Barr, U.-K.; Bertilsson, J.; Borch, E.; Brunius, C.; Emanuelsson, M.; Göransson, L.; Gunnarsson, S.; et al. Paths to a sustainable food sector: Integrated design and LCA of future food supply chains: The case of pork production in Sweden. Int. J. Life Cycle Assess. 2016, 21, 664-676. [CrossRef]

1035. Sonnino, R. The new geography of food security: Exploring the potential of urban food strategies. Geogr. J. 2016, 182, 190-200. [CrossRef]

1036. Sonnino, R.; Marsden, T.; Moragues-Faus, A. Relationalities and convergences in food security narratives: Towards a place-based approach. Trans. Inst. Br. Geogr. 2016, 41, 477-489. [CrossRef]

1037. Springmann, M.; Godfray, H.C.J.; Rayner, M.; Scarborough, P. Analysis and valuation of the health and climate change cobenefits of dietary change. Proc. Natl. Acad. Sci. USA 2016, 113, 4146-4151. [CrossRef]

1038. Średnicka-Tober, D.; Kazimierczak, R.; Hallmann, E. European Organic Food Consumers: Motives, Actions and Implications. Probl. Zarz. 2016, 58, 100-108. [CrossRef]

1039. Stevens, T.; Aarts, N.; Termeer, C.; Dewulf, A. Social media as a new playing field for the governance of agro-food sustainability. Curr. Opin. Environ. Sustain. 2016, 18, 99-106. [CrossRef]

1040. Svenfelt, Å.; Zapico, J.L. Sustainable food systems with ICT? In Proceedings of the Proceedings of the 4th International Conference on ICT for Sustainability (ICT4S 2016), Amsterdam, The Netherlands, 29 August-1 September 2016; Grosso, P., Lago, P., Osseyran, A., Eds.; Atlantis Press: Paris, France, 2016; pp. 194-201.

1041. Thyberg, K.L.; Tonjes, D.J. Drivers of food waste and their implications for sustainable policy development. Resour. Conserv. Recycl. 2016, 106, 110-123. [CrossRef]

1042. Uwizeye, A.; Gerber, P.J.; Schulte, R.P.O.; de Boer, I.J.M. A comprehensive framework to assess the sustainability of nutrient use in global livestock supply chains. J. Clean. Prod. 2016, 129, 647-658. [CrossRef]

1043. Valenzuela, H. Agroecology: A global paradigm to challenge mainstream industrial agriculture. Horticulturae 2016, $2,2$. [CrossRef]

1044. Van den Broeck, G.; Maertens, M. Horticultural exports and food security in developing countries. Glob. Food Sec. 2016, 10, 11-20. [CrossRef]

1045. Viola, I.; Marinelli, A. Life cycle assessment and environmental sustainability in the food system. Agric. Agric. Sci. Procedia 2016, 8, 317-323. [CrossRef]

1046. Voinea, L.; Atanase, A.; Schileru, I. Perceptions of the slow food cultural trend among the youth. Amfiteatru Econ. 2016, 18, 847-861.

1047. Warshawsky, D.N. Food waste, sustainability, and the corporate sector: Case study of a US food company. Geogr. J. 2016, 182, 384-394. [CrossRef]

1048. Wilson, M. Food and nutrition security policies in the Caribbean: Challenging the corporate food regime? Geoforum 2016, 73, 60-69. [CrossRef]

1049. Wu, H.; Gao, L.; Yuan, Z.; Wang, S. Life cycle assessment of phosphorus use efficiency in crop production system of three crops in Chaohu Watershed, China. J. Clean. Prod. 2016, 139, 1298-1307. [CrossRef]

1050. Yamashita, L.; Robinson, D. Making Visible the People Who Feed Us: Educating for Critical Food Literacy Through Multicultural Texts. J. Agric. Food Syst. Community Dev. 2016, 6, 269-281. [CrossRef]

1051. Zimdahl, R.L.; Holtzer, T.O. The Ethical Values in the U.S. Agricultural and Food System. J. Agric. Environ. Ethics 2016, 29, 549-557. [CrossRef]

1052. Zirham, M.; Palomba, R. Female Agriculture in the Short Food Supply Chain: A New Path towards the Sustainability Empowerment. Agric. Agric. Sci. Procedia 2016, 8, 372-377. [CrossRef]

1053. Alajmi, F.; Somerset, S.M. Food system sustainability and vulnerability: Food acquisition during the military occupation of Kuwait. Public Health Nutr. 2015, 18, 3060-3066. [CrossRef]

1054. Allen, M.G. Framing food security in the Pacific Islands: Empirical evidence from an island in the Western Pacific. Reg. Environ. Chang. 2015, 15, 1341-1353. [CrossRef]

1055. Barbeau, C.; Oelbermann, M.; Karagatzides, J.; Tsuji, L. Sustainable Agriculture and Climate Change: Producing Potatoes (Solanum tuberosum L.) and Bush Beans (Phaseolus vulgaris L.) for Improved Food Security and Resilience in a Canadian Subarctic First Nations Community. Sustainability 2015, 7, 5664-5681. [CrossRef]

1056. Belletti, M. The emerging role of the peasant economy at the end of the industrial age: Insights from Albania. Procedia Econ. Financ. 2015, 33, 78-89. [CrossRef]

1057. Black, J.L.; Velazquez, C.E.; Ahmadi, N.; Chapman, G.E.; Carten, S.; Edward, J.; Shulhan, S.; Stephens, T.; Rojas, A. Sustainability and public health nutrition at school: Assessing the integration of healthy and environmentally sustainable food initiatives in Vancouver schools. Public Health Nutr. 2015, 18, 2379-2391. [CrossRef]

1058. Borska, J.; Kadlecova, E. Legal Aspects of Agricultural Land in the Czech Republic. In Proceedings of the 24th International Scientific Conference on Agrarian Perspectives-Global Agribusiness and the Rural Economy; Smutka, L., Rezbova, H., Eds.; Czech University Life Sciences Prague: Prague, 2015; pp. 73-81.

1059. Brinsden, H.; Lang, T. Reflecting on ICN2: Was it a game changer? Arch. Public Health 2015, 73, 42. [CrossRef]

1060. Burke, J.; Spiller, K. Food solutions new england: Racial equity, food justice, and food system transformation. J. Agric. Food Syst. Community Dev. 2015, 5, 165-171. [CrossRef]

1061. Cadieux, K.; Slocum, R. What does it mean to do food justice? J. Polit. Ecol. 2015, 22, 1-26. [CrossRef] 
1062. Carolan, M. Affective sustainable landscapes and care ecologies: Getting a real feel for alternative food communities. Sustain. Sci. 2015, 10, 317-329. [CrossRef]

1063. Carroll, B.E.; Fahy, F. Locating the locale of local food: The importance of context, space and social relations. Renew. Agric. Food Syst. 2015, 30, 563-576. [CrossRef]

1064. Casolani, N. Sustainability of Short Food Supply Chain System in Europe: A SWOT Analysis. Glob. Local Econ. Rev. 2015, 19, 61-86.

1065. Chaudhury, S.R.; Albinsson, P.A. Citizen-Consumer Oriented Practices in Naturalistic Foodways. J. Macromarketing 2015, 35, 36-52. [CrossRef]

1066. Christensen, L.; O'Sullivan, R. Using social networking analysis to measure changes in regional food systems collaboration: A methodological framework. J. Agric. Food Syst. Community Dev. 2015, 113-129. [CrossRef]

1067. Cisneros-Saguilán, P.; Gallardo-López, F.; López-Ortíz, S.; Ruiz Rosado, O.; Herrera-Haro, J.G.; Hernández-Castro, E. Current Epistemological Perceptions of Sustainability and Its Application in the Study and Practice of Cattle Production: A Review. Agroecol. Sustain. Food Syst. 2015, 39, 885-906. [CrossRef]

1068. Clapp, J. Distant agricultural landscapes. Sustain. Sci. 2015, 10, 305-316. [CrossRef]

1069. Clausen, R.; Clark, B.; Longo, S.B. Metabolic Rifts and Restoration: Agricultural Crises and the Potential of Cuba's Organic, Socialist Approach to Food Production. World Rev. Polit. Econ. 2015, 6, 4-32. [CrossRef]

1070. CoDyre, M.; Fraser, E.D.G.; Landman, K. How does your garden grow? An empirical evaluation of the costs and potential of urban gardening. Urban For. Urban Green. 2015, 14, 72-79. [CrossRef]

1071. Cohen, N.; Ilieva, R.T. Transitioning the food system: A strategic practice management approach for cities. Environ. Innov. Soc. Transit. 2015, 17, 199-217. [CrossRef]

1072. Cohen, N.; Reynolds, K. Resource needs for a socially just and sustainable urban agriculture system: Lessons from New York City. Renew. Agric. Food Syst. 2015, 30, 103-114. [CrossRef]

1073. Cook, J.; Oviatt, K.; Main, D.S.; Kaur, H.; Brett, J. Re-conceptualizing urban agriculture: An exploration of farming along the banks of the Yamuna River in Delhi, India. Agric. Hum. Values 2015, 32, 265-279. [CrossRef]

1074. Cordell, D.; White, S. Tracking phosphorus security: Indicators of phosphorus vulnerability in the global food system. Food Secur. 2015, 7, 337-350. [CrossRef]

1075. Dentoni, D.; Bitzer, V. The role(s) of universities in dealing with global wicked problems through multi-stakeholder initiatives. J. Clean. Prod. 2015, 106, 68-78. [CrossRef]

1076. Farber, D.A. Separated at Birth? Addressing the Twin Crises of Biodiversity and Climate Change. Ecol. Law Q. 2015, 42, 841-888. [CrossRef]

1077. Forssell, S.; Lankoski, L. The sustainability promise of alternative food networks: An examination through "alternative" characteristics. Agric. Hum. Values 2015, 32, 63-75. [CrossRef]

1078. Frankova, E. Quest for Sustainable Food Production: Social and Financial Metabolism of a Local Food system. In Proceedings of the 9th International Scientific Conference on INPROFORUM, Ceske Budejovic, Czech Republic, 5-6 November 2015; Pech, M., Ed.; Faculty of Economics, University of South Bohemia Ceske Budejovic: Ceske Budejovic, Czech Republic, 2015 ; pp. 47-53.

1079. Göbel, C.; Langen, N.; Blumenthal, A.; Teitscheid, P.; Ritter, G. Cutting food waste through cooperation along the food supply chain. Sustainability 2015, 7, 1429-1445. [CrossRef]

1080. Godfray, H.C.J.; Robinson, S. Contrasting approaches to projecting long-run global food security. Oxford Rev. Econ. Policy 2015, 31, 26-44. [CrossRef]

1081. Grivins, M.; Tisenkopfs, T. A discursive analysis of oppositional interpretations of the agro-food system: A case study of Latvia. J. Rural Stud. 2015, 39, 111-121. [CrossRef]

1082. Hallström, E.; Carlsson-Kanyama, A.; Börjesson, P. Environmental impact of dietary change: A systematic review. J. Clean. Prod. 2015, 91, 1-11. [CrossRef]

1083. Holben, D.H.; Morrone, M. Development of an EcoNutrition Café Series to Increase Awareness and Knowledge of a Sustainable, Local Food System in Appalachian Ohio. J. Hunger Environ. Nutr. 2015, 10, 293-296. [CrossRef]

1084. Horst, M.; Gaolach, B. The potential of local food systems in North America: A review of foodshed analyses. Renew. Agric. Food Syst. 2015, 30, 399-407. [CrossRef]

1085. Hu, X.; Sheng, X.; Liu, L.; Ma, Z.; Li, X.; Zhao, W. Food system advances towards more nutritious and sustainable mantou production in China. Asia Pac. J. Clin. Nutr. 2015, 24, 199-205. [CrossRef] [PubMed]

1086. James, S.W.; Friel, S. An integrated approach to identifying and characterising resilient urban food systems to promote population health in a changing climate. Public Health Nutr. 2015, 18, 2498-2508. [CrossRef]

1087. Jenkins, A.; Keeffe, G.; Hall, N. Planning Urban Food Production into Today's Cities. Futur. Food J. Food Agric. Soc. 2015, 3, 35-47.

1088. Johnson, H. Eating for Health and the Environment: Australian Regulatory Responses For Dietary Change. QUT Law Rev. 2015, 15, 122. [CrossRef]

1089. Jonkman, J.; Bloemhof, J.M.; van der Vorst, J.G.A.J.; van der Padt, A. A Sustainability Driven Methodology for Process Synthesis in Agro-Food Industry. In Proceedings of the 12th International Symposium on Process Systems Engineering (PSE)/25th European Symposium on Computer Aided Process Engineering (ESCAPE); Gernaey, K., Huusom, J., Gani, R., Eds.; Elsevier Science BV: Amsterdam, The Netherlands, 2015; pp. 1289-1294. 
1090. Kaput, J.; Kussmann, M.; Mendoza, Y.; Le Coutre, R.; Cooper, K.; Roulin, A. Enabling nutrient security and sustainability through systems research. Genes Nutr. 2015, 10, 12. [CrossRef]

1091. Kopainsky, B.; Huber, R.; Pedercini, M. Food Provision and Environmental Goals in the Swiss Agri-Food System: System Dynamics and the Social-ecological Systems Framework. Syst. Res. Behav. Sci. 2015, 32, 414-432. [CrossRef]

1092. Krivasonoka, I.; Silina, L. Theoretical Aspects of Local Food Distribution. In Proceedings of the 21st Annual International Scientific Conference Research for Rural Development, Jelgava, Latvia, 13-15 May 2015; Treija, S., Skujeniece, S., Eds.; Latvia University of Life Sciences and Technologies: Jelgava, Latvia, 2015; pp. 276-283.

1093. Krone, A. "A Shmita Manifesto"-A radical sabbatical approach to Jewish food reform in the United States. In Proceedings of the Donner Symposium on Religion and Food, Turku, Finland, 25-27 June 2014; Illman, R., Dahla, B., Eds.; The Donner Institute for Research in Religious and Cultural History: Abo, Finland, 2015; pp. 303-325.

1094. Kuhnlein, H.V. Food system sustainability for health and well-being of Indigenous Peoples. Public Health Nutr. 2015, 18, 2415-2424. [CrossRef]

1095. Langen, N.; Göbel, C.; Waskow, F. The effectiveness of advice and actions in reducing food waste. Proc. Inst. Civ. Eng. Waste Resour. Manag. 2015, 168, 72-86. [CrossRef]

1096. Marshall, G.R. A social-ecological systems framework for food systems research: Accommodating transformation systems and their products. Int. J. Commons 2015, 9, 881. [CrossRef]

1097. Melece, L.; Krievina, A. Development of Local Food systems in Latvia. In Proceedings of the 21st Annual International Scientific Conference Research for Rural Development, Jelgava, Latvia, 13-15 May 2015; Treija, S., Skujeniece, S., Eds.; Latvia University of Life Sciences and Technologies: Jelgava, Latvia, 2015; pp. 104-111.

1098. Metson, G.S.; Bennett, E.M. Phosphorus Cycling in Montreal's Food and Urban Agriculture Systems. PLoS ONE 2015, 10, e0120726. [CrossRef]

1099. Migliore, G.; Di Gesaro, M.; Borsellino, V.; Asciuto, A.; Schimmenti, E. Understanding consumer demand for sustainable beef production in rural. Qual. Success 2015, 16, 75-79.

1100. Monroe, J.T.; Lofgren, I.E.; Sartini, B.L.; Greene, G.W. The green eating project: Web-based intervention to promote environmentally conscious eating behaviours in US university students. Public Health Nutr. 2015, 18, 2368-2378. [CrossRef]

1101. Moragues-Faus, A.; Morgan, K. Reframing the foodscape: The emergent world of urban food policy. Environ. Plan. A Econ. Sp. 2015, 47, 1558-1573. [CrossRef]

1102. Morgan, K. Nourishing the city: The rise of the urban food question in the Global North. Urban Stud. 2015, 52, 1379-1394. [CrossRef]

1103. Motloch, J.L.; Truex, S. Living within humanity's life-support system. Procedia Eng. 2015, 118, 412-419. [CrossRef]

1104. Nuutila, J. Acceptance of the Most Common Quality Attributes of Organic Food in the Finnish Food Chain. In Proceedings of the 25th NJF Congress on Nordic View to Sustainable Rural Development, Riga, Latvia, 16-18 June 2015; ZeverteRivza, S., Ed.; Nordic Association of Agricultural Science-NJF: Uppsala, Sweden, 2015; pp. 318-323.

1105. Pirog, R.; Koch, K.; Guel, A. Race, Ethnicity, and the Promise of "Good Food" for Michigan: A Three-voice Commentary. J. Agric. Food Syst. Community Dev. 2015, 5, 83-86. [CrossRef]

1106. Pothukuchi, K.; Molnar, S.A. Sustainable Food Systems at Urban Public Universities: A Survey of U-21 Universities. J. Urban Aff. 2015, 37, 341-359. [CrossRef]

1107. Rémésy, C.; Leenhardt, F.; Fardet, A. Donner un nouvel avenir au pain dans le cadre d'une alimentation durable et préventive. Cah. Nutr. Diététique 2015, 50, 39-46. [CrossRef]

1108. Saracin, V.-C.; Vasile, A. An Exploratory Research Regarding Romanian Organic Farming Sector. Agrolife Sci. J. $2015,4,119-123$.

1109. Schader, C.; Muller, A.; Scialabba, N.E.-H.; Hecht, J.; Isensee, A.; Erb, K.-H.; Smith, P.; Makkar, H.P.S.; Klocke, P.; Leiber, F.; et al. Impacts of feeding less food-competing feedstuffs to livestock on global food system sustainability. J. R. Soc. Interface 2015, 12, 20150891. [CrossRef]

1110. Shimokawa, S. Sustainable meat consumption in China. J. Integr. Agric. 2015, 14, 1023-1032. [CrossRef]

1111. Springer, N.P.; Garbach, K.; Guillozet, K.; Haden, V.R.; Hedao, P.; Hollander, A.D.; Huber, P.R.; Ingersoll, C.; Langner, M.; Lipari, G.; et al. Sustainable Sourcing of Global Agricultural Raw Materials: Assessing Gaps in Key Impact and Vulnerability Issues and Indicators. PLoS ONE 2015, 10, e0128752. [CrossRef] [PubMed]

1112. Stanciu, S.; Bichescu, C.I.; Virlanuta, F.O.; Sarbu, R. Global and National Perspectives Regarding Food Wastage. In Proceedings of the 26th International-Business-Information-Management-Association Conference, Madrid, Spain, 11-12 November 2015; Soliman, K., Ed.; International Business Information Management Association-IBIMA: Norristown, PA, USA, 2015; pp. $2477-2488$.

1113. Straujuma, L. Climate change and agriculture: Multiple responses and responsibilities. EuroChoices 2015, 14, 4-10. [CrossRef]

1114. Sumner, J.; Wever, C. Cultivating alliances: The local organic food co-ops network. Can. J. Nonprofit Soc. Econ. Res. 2015, 6, 65-79. [CrossRef]

1115. Tanaka, K.; Indiano, E.; Soley, G.; Mooney, P. Print E-mail Building the Capacity for Community Food Work: The Geographic Distribution of USDA Community Food Projects Competitive Grant Program Grantees. J. Agric. Food Syst. Community Dev. 2015, 5, 97-111. [CrossRef]

1116. Tendall, D.M.; Joerin, J.; Kopainsky, B.; Edwards, P.; Shreck, A.; Le, Q.B.; Kruetli, P.; Grant, M.; Six, J. Food system resilience: Defining the concept. Glob. Food Sec. 2015, 6, 17-23. [CrossRef]

1117. Tieman, M.; Hassan, F.H. Convergence of food systems: Kosher, Christian and Halal. Br. Food J. 2015, 117, 2313-2327. [CrossRef] 
1118. Tjärnemo, H.; Södahl, L. Swedish food retailers promoting climate smarter food choices—Trapped between visions and reality? J. Retail. Consum. Serv. 2015, 24, 130-139. [CrossRef]

1119. Tsuchiya, K.; Hara, Y.; Thaitakoo, D. Linking food and land systems for sustainable peri-urban agriculture in Bangkok Metropolitan Region. Landsc. Urban Plan. 2015, 143, 192-204. [CrossRef]

1120. Vaarst, M.; Steenfeldt, S.; Horsted, K. Sustainable development perspectives of poultry production. Worlds. Poult. Sci. J. 2015, 71, 609-620. [CrossRef]

1121. Vittersø, G.; Tangeland, T. The role of consumers in transitions towards sustainable food consumption. The case of organic food in Norway. J. Clean. Prod. 2015, 92, 91-99. [CrossRef]

1122. Winters, P.; Kuo, H.-W.; Niljinda, C.; Chen, B.; Alves-Pinto, H.N.; Ongun, M.; Daryanto, S.; Newton, P. Voluntary Certification Design Choices Influence Producer Participation, Stakeholder Acceptance, and Environmental Sustainability in Commodity Agriculture Sectors in Tropical Forest Landscapes. J. Sustain. For. 2015, 34, 581-604. [CrossRef]

1123. Zampi, M. Innovation into agri-food system: The case of nutrition \& sante. Qual. Success 2015, 16, 80-84.

1124. Zhao, B.; Zhang, J.-E.; Li, H.; Xu, H.; Quan, G.; An, M. Effect of lolium multiflorum lam. as a substitute feedstuff for ducks in a rice-duck farming system. Agroecol. Sustain. Food Syst. 2015, 39, 727-746. [CrossRef]

1125. Ackerman, K.; Conard, M.; Culligan, P.; Plunz, R.; Sutto, M.-P.; Whittinghill, L. Sustainable Food systems for future cities: The potential of urban agriculture. Econ. Soc. Rev. 2014, 45, 189-206.

1126. Becker, B.; Zoss, M.; Lehmann, H.-J. Global food security-The consequences for Switzerland. Agrar. Schweiz $2014,5,138-145$.

1127. Blecha, J.; Leitner, H. Reimagining the food system, the economy, and urban life: New urban chicken-keepers in US cities. Urban Geogr. 2014, 35, 86-108. [CrossRef]

1128. Caputo, P.; Ducoli, C.; Clementi, M. Strategies and tools for eco-efficient local food supply scenarios. Sustainability 2014, 6, 631-651. [CrossRef]

1129. Challies, E.; Newig, J.; Lenschow, A. What role for social-ecological systems research in governing global teleconnections? Glob. Environ. Chang. 2014, 27, 32-40. [CrossRef]

1130. Cleveland, D.A.; Müller, N.M.; Tranovich, A.C.; Mazaroli, D.N.; Hinson, K. Local food hubs for alternative food systems: A case study from Santa Barbara County, California. J. Rural Stud. 2014, 35, 26-36. [CrossRef]

1131. Climent-López, E.; Sánchez-Hernández, J.L.; Canto-Fresno, C.; Alonso-Santos, J.L.; Ramírez-García, S.; Rodero-González, V.; Ruiz-Budría, E. Measuring quality conventions in the food industry: Applications to the wine sector in Spain. Geoforum 2014, 56, 148-160. [CrossRef]

1132. Cordell, D.; Neset, T.-S.S. Phosphorus vulnerability: A qualitative framework for assessing the vulnerability of national and regional food systems to the multi-dimensional stressors of phosphorus scarcity. Glob. Environ. Chang. 2014, 24, 108-122. [CrossRef]

1133. Cordell, D.; White, S. Life's Bottleneck: Sustaining the World's Phosphorus for a Food Secure Future. Annu. Rev. Environ. Resour. 2014, 39, 161-188. [CrossRef]

1134. Davis, K.F.; D'Odorico, P.; Rulli, M.C. Moderating diets to feed the future. Earth's Futur. 2014, 2, 559-565. [CrossRef]

1135. Fanzo, J. Strengthening the engagement of food and health systems to improve nutrition security: Synthesis and overview of approaches to address malnutrition. Glob. Food Sec. 2014, 3, 183-192. [CrossRef]

1136. Fielke, S.J.; Bardsley, D.K. The importance of farmer education in South Australia. Land Use policy 2014, 39, 301-312. [CrossRef]

1137. Francis, C.; Van Wart, J.; Johnson, B. How to regenerate rural community and ecoservices: Reversing the tragedy of the commons. Agron. J. 2014, 106, 95-99. [CrossRef]

1138. Godfray, H.C.J. The challenge of feeding 9-10 billion people equitably and sustainably. J. Agric. Sci. 2014, 152, 2-8. [CrossRef]

1139. Goonan, S.; Mirosa, M.; Spence, H. Getting a Taste for Food Waste: A mixed methods ethnographic study into hospital food waste before patient consumption conducted at three New Zealand foodservice facilities. J. Acad. Nutr. Diet. 2014, 114, 63-71. [CrossRef]

1140. Halloran, A.; Clement, J.; Kornum, N.; Bucatariu, C.; Magid, J. Addressing food waste reduction in Denmark. Food Policy 2014, 49, 294-301. [CrossRef]

1141. Hoekstra, A.Y. Water for animal products: A blind spot in water policy. Environ. Res. Lett. 2014, 9, 091003. [CrossRef]

1142. Isakson, S.R. Maize diversity and the political economy of agrarian restructuring in Guatemala. J. Agrar. Chang. 2014, 14, 347-379. [CrossRef]

1143. Johnston, J.L.; Fanzo, J.C.; Cogill, B. Understanding sustainable diets: A descriptive analysis of the determinants and processes that influence diets and their impact on health, food security, and environmental sustainability. Adv. Nutr. 2014, 5, 418-429. [CrossRef]

1144. Kjrgard, B.; Land, B.; Bransholm Pedersen, K. Health and sustainability. Health Promot. Int. 2014, 29, 558-568. [CrossRef]

1145. Lamppa, J.W.; Horn, G.; Edwards, D. Toward the redesign of nutrition delivery. J. Control. Release 2014, 190, 201-209. [CrossRef]

1146. Marschke, M.; Wilkings, A. Is certification a viable option for small producer fish farmers in the global south? Insights from Vietnam. Mar. Policy 2014, 50, 197-206. [CrossRef]

1147. Monardo, B.; Palazzo, A.L. Challenging inclusivity urban agriculture and community involvement in San Diego. Adv. Eng. Forum 2014, 11, 356-363. [CrossRef]

1148. Moresi, M. Assessment of the life cycle greenhouse gas emissions in the food industry. Agro Food Ind. Hi. Tech. $2014,25,53-62$. 
1149. Odegard, I.Y.R.; van der Voet, E. The future of food-Scenarios and the effect on natural resource use in agriculture in 2050. Ecol. Econ. 2014, 97, 51-59. [CrossRef]

1150. Olson, J.; Clay, P.M.; Pinto da Silva, P. Putting the seafood in sustainable food systems. Mar. Policy 2014, 43, 104-111. [CrossRef]

1151. Peano, C.; Migliorini, P.; Sottile, F. A methodology for the sustainability assessment of agri-food systems: An application to the Slow Food Presidia project. Ecol. Soc. 2014, 19, art24. [CrossRef]

1152. Pearson, D.; Friel, S.; Lawrence, M. Building environmentally sustainable food systems on informed citizen choices: Evidence from Australia. Biol. Agric. Hortic. 2014, 30, 183-197. [CrossRef]

1153. Pereira, L.M.; Cuneo, C.N.; Twine, W.C. Food and cash: Understanding the role of the retail sector in rural food security in South Africa. Food Secur. 2014, 6, 339-357. [CrossRef]

1154. Ridoutt, B.G.; Baird, D.L.; Bastiaans, K.; Darnell, R.; Hendrie, G.A.; Riley, M.; Sanguansri, P.; Syrette, J.; Noakes, M.; Keating, B.A. Short communication: A food-systems approach to assessing dairy product waste. J. Dairy Sci. 2014, 97, 6107-6110. [CrossRef]

1155. Senanayake, N.; Mukherji, A. Irrigating with arsenic contaminated groundwater in West Bengal and Bangladesh: A review of interventions for mitigating adverse health and crop outcomes. Agric. Water Manag. 2014, 135, 90-99. [CrossRef]

1156. Sneyd, A. Cameroon: Perspectives on Food Security and the Emerging Power Footprint. Sustainability 2014, 6, 1868-1895. [CrossRef]

1157. Specht, K.; Siebert, R.; Hartmann, I.; Freisinger, U.B.; Sawicka, M.; Werner, A.; Thomaier, S.; Henckel, D.; Walk, H.; Dierich, A. Urban agriculture of the future: An overview of sustainability aspects of food production in and on buildings. Agric. Human Values 2014, 31, 33-51. [CrossRef]

1158. Thorsøe, M.H.; Alrøe, H.F.; Noe, E. Observing the observers: Uncovering the role of values in research assessments of organic food systems. Ecol. Soc. 2014, 19, art46. [CrossRef]

1159. Van Mil, H.G.J.; Foegeding, E.A.; Windhab, E.J.; Perrot, N.; van der Linden, E. A complex system approach to address world challenges in food and agriculture. Trends Food Sci. Technol. 2014, 40, 20-32. [CrossRef]

1160. Voisin, A.-S.; Guéguen, J.; Huyghe, C.; Jeuffroy, M.-H.; Magrini, M.-B.; Meynard, J.-M.; Mougel, C.; Pellerin, S.; Pelzer, E. Legumes for feed, food, biomaterials and bioenergy in Europe: A review. Agron. Sustain. Dev. 2014, 34, 361-380. [CrossRef]

1161. Walter, A.; Grieder, C.; Last, L.; Keller, B.; Hund, A.; Studer, B. The Swiss plant breeding sector-A spatial, temporal and thematic analysis. Agrar. Schweiz 2014, 5, 366-373.

1162. Wegerif, M. Exploring Sustainable Urban Food Provisioning: The case of eggs in dar es salaam. Sustainability 2014, 6, 3747-3779. [CrossRef]

1163. Werkheiser, I.; Noll, S. From food justice to a tool of the status quo: Three sub-movements within local food. J. Agric. Environ. Ethics 2014, 27, 201-210. [CrossRef]

1164. West, P.C.; Gerber, J.S.; Engstrom, P.M.; Mueller, N.D.; Brauman, K.A.; Carlson, K.M.; Cassidy, E.S.; Johnston, M.; MacDonald, G.K.; Ray, D.K.; et al. Leverage points for improving global food security and the environment. Science 2014, 345, 325-328. [CrossRef] [PubMed]

1165. Yach, D. Food industry: Friend or foe? Obes. Rev. 2014, 15, 2-5. [CrossRef]

1166. Zanecchia, A.L. Tobacco Dependency, Sustainable Agriculture, and Regional Food Security-A Case Study in Malawi. In Proceedings of the 8th International Technology, Education and Development Conference (INTED), Valencia, Spain, 10-12 March 2014; Chova, L.G., Martinez, A.L., Torres, I., Eds.; IATED—International Academy of Technology, Education and Development: Valencia, Spain, 2014; pp. 4529-4535.

1167. Cassidy, E.S.; West, P.C.; Gerber, J.S.; Foley, J.A. Redefining agricultural yields: From tonnes to people nourished per hectare. Environ. Res. Lett. 2013, 8, 034015. [CrossRef]

1168. Cembalo, L.; Migliore, G.; Schifani, G. Sustainability and new models of consumption: The solidarity purchasing groups in sicily. J. Agric. Environ. Ethics 2013, 26, 281-303. [CrossRef]

1169. Cordell, D.; Jackson, M.; White, S. Phosphorus flows through the Australian food system: Identifying intervention points as a roadmap to phosphorus security. Environ. Sci. Policy 2013, 29, 87-102. [CrossRef]

1170. Crivits, M.; Paredis, E. Designing an explanatory practice framework: Local food systems as a case. J. Consum. Cult. 2013, 13, 306-336. [CrossRef]

1171. Dicks, L.; Bardgett, R.; Bell, J.; Benton, T.; Booth, A.; Bouwman, J.; Brown, C.; Bruce, A.; Burgess, P.; Butler, S.; et al. What do we need to know to enhance the environmental sustainability of agricultural production? A prioritisation of knowledge needs for the UK food system. Sustainability 2013, 5, 3095-3115. [CrossRef]

1172. Fernandez, M.; Goodall, K.; Olson, M.; Méndez, V.E. Agroecology and alternative agri-food movements in the United States: Toward a sustainable agri-food system. Agroecol. Sustain. Food Syst. 2013, 37, 115-126. [CrossRef]

1173. Fraser, E.D.G. Coping with food crises: Lessons from the American Dust Bowl on balancing local food, agro technology, social welfare, and government regulation agendas in food and farming systems. Glob. Environ. Chang. 2013, 23, 1662-1672. [CrossRef]

1174. Galt, R.E.; Parr, D.; Van Soelen Kim, J.; Beckett, J.; Lickter, M.; Ballard, H. Transformative food systems education in a land-grant college of agriculture: The importance of learner-centered inquiries. Agric. Human Values 2013, 30, 129-142. [CrossRef]

1175. Garnett, T. Food sustainability: Problems, perspectives and solutions. Proc. Nutr. Soc. 2013, 72, 29-39. [CrossRef]

1176. Gerlach, S.C.; Loring, P.A. Rebuilding northern foodsheds, sustainable food systems, community well-being, and food security. Int. J. Circumpolar Health 2013, 72, 21560. [CrossRef] 
1177. Glowacki-Dudka, M.; Murray, J.; Isaacs, K.P. Examining social capital within a local food system. Community Dev. J. 2013, 48, 75-88. [CrossRef]

1178. Gonzalez de Molina, M. Agroecology and politics. How to get sustainability? About the Necessity for a political agroecology. Agroecol. Sustain. Food Syst. 2013, 37, 45-59. [CrossRef]

1179. Hamilton, H. Sustainable food lab learning systems for inclusive business models worldwide. Int. Food Agribus. Manag. Rev. 2013, 16, 33-37.

1180. Hinrichs, C.C. Regionalizing food security? Imperatives, intersections and contestations in a post-9/11 world. J. Rural Stud. 2013, 29, 7-18. [CrossRef]

1181. Ingram, J.S.I.; Wright, H.L.; Foster, L.; Aldred, T.; Barling, D.; Benton, T.G.; Berryman, P.M.; Bestwick, C.S.; Bows-Larkin, A.; Brocklehurst, T.F.; et al. Priority research questions for the UK food system. Food Secur. 2013, 5, 617-636. [CrossRef]

1182. Johns, T.; Powell, B.; Maundu, P.; Eyzaguirre, P.B. Agricultural biodiversity as a link between traditional food systems and contemporary development, social integrity and ecological health. J. Sci. Food Agric. 2013, 93, 3433-3442. [CrossRef]

1183. Kneafsey, M.; Dowler, E.; Lambie-Mumford, H.; Inman, A.; Collier, R. Consumers and food security: Uncertain or empowered? J. Rural Stud. 2013, 29, 101-112. [CrossRef]

1184. MacRae, R.; Cuddeford, V.; Young, S.B.; Matsubuchi-Shaw, M. The food system and climate change: An exploration of emerging strategies to reduce GHG emissions in Canada. Agroecol. Sustain. Food Syst. 2013, 37, 933-963. [CrossRef]

1185. McLachlan, M.; Landman, A.P. Nutrition-sensitive agriculture-A South African perspective. Food Secur. 2013, 5, 857-871. [CrossRef]

1186. Pereira, L. The future of the food system: Cases involving the private sector in South Africa. Sustainability 2013, 5, 1234-1255. [CrossRef]

1187. Rosin, C. Food security and the justification of productivism in New Zealand. J. Rural Stud. 2013, 29, 50-58. [CrossRef]

1188. Shey, J.E.; Belis, D. Building a municipal food policy regime in minneapolis: Implications for Urban Climate Governance. Environ. Plan. C Gov. Policy 2013, 31, 893-910. [CrossRef]

1189. Sodano, V.; Hingley, M. The food system, climate change and CSR: From business to government case. Br. Food J. 2013, 115, 75-91. [CrossRef]

1190. Sonnino, R. Local foodscapes: Place and power in the agri-food system. Acta Agric. Scand. Sect. B Soil Plant Sci. 2013, 63, 2-7. [CrossRef]

1191. Spiegelaar, N.F.; Tsuji, L.J.S. Impact of Euro-Canadian agrarian practices: In search of sustainable import-substitution strategies to enhance food security in subarctic Ontario, Canada. Rural Remote Health 2013, 13, A2211.

1192. Spiegelaar, N.; Tsuji, L.; Oelbermann, M. The Potential Use of Agroforestry Community Gardens as a Sustainable ImportSubstitution Strategy for Enhancing Food Security in Subarctic Ontario, Canada. Sustainability 2013, 5, 4057-4075. [CrossRef]

1193. Vinceti, B.; Termote, C.; Ickowitz, A.; Powell, B.; Kehlenbeck, K.; Hunter, D. The Contribution of Forests and Trees to Sustainable Diets. Sustainability 2013, 5, 4797-4824. [CrossRef]

1194. White, R.; Stirling, A. Sustaining trajectories towards Sustainability: Dynamics and diversity in UK communal growing activities. Glob. Environ. Chang. 2013, 23, 838-846. [CrossRef]

1195. Anthony, R. The Ethics of Food for Tomorrow: On the Viability of Agrarianism-How Far can it Go? Comments on Paul Thompson's Agrarian Vision. J. Agric. Environ. Ethics 2012, 25, 543-552. [CrossRef]

1196. Blanc, J.; Kledal, P.R. The Brazilian organic food sector: Prospects and constraints of facilitating the inclusion of smallholders. J. Rural Stud. 2012, 28, 142-154. [CrossRef]

1197. Brunori, G.; Rossi, A.; Guidi, F. On the New Social Relations around and beyond Food. Analysing Consumers' Role and Action in Gruppi di Acquisto Solidale (Solidarity Purchasing Groups). Sociol. Rural. 2012, 52, 1-30. [CrossRef]

1198. Elser, J.J. Phosphorus: A limiting nutrient for humanity? Curr. Opin. Biotechnol. 2012, 23, 833-838. [CrossRef]

1199. Erb, K.-H.; Haberl, H.; Plutzar, C. Dependency of global primary bioenergy crop potentials in 2050 on food systems, yields, biodiversity conservation and political stability. Energy Policy 2012, 47, 260-269. [CrossRef]

1200. Kremen, C.; Iles, A.; Bacon, C. Diversified Farming Systems: An Agroecological, Systems-based Alternative to Modern Industrial Agriculture. Ecol. Soc. 2012, 17, art44. [CrossRef]

1201. Lang, T.; Barling, D. Food security and food sustainability: Reformulating the debate. Geogr. J. 2012, 178, 313-326. [CrossRef]

1202. MacMillan, T.; Dowler, E. Just and Sustainable? Examining the Rhetoric and Potential Realities of UK Food Security. J. Agric. Environ. Ethics 2012, 25, 181-204. [CrossRef]

1203. MacRae, R.; Szabo, M.; Anderson, K.; Louden, F.; Trillo, S. Empowering the citizen-consumer: Re-regulating consumer information to support the transition to sustainable and health promoting food systems in Canada. Sustainability 2012, 4, 2146-2175. [CrossRef]

1204. Melece, L. Local Food systems for Sustainable Rural Development. In Proceedings of the 13th International Scientific Conference on Economic Science for Rural Development, Jelgava, Latvia, 26-27 April 2012; Zvirbule-Berzina, A., Ed.; Latvia University of Agriculture: Jelgava, Latvia, 2012; pp. 152-158.

1205. Metson, G.; Aggarwal, R.; Childers, D.L. Efficiency Through Proximity. J. Ind. Ecol. 2012, 16, 914-927. [CrossRef]

1206. Morrison, K.T.; Nelson, T.A.; Nathoo, F.S.; Ostry, A.S. Application of Bayesian spatial smoothing models to assess agricultural self-sufficiency. Int. J. Geogr. Inf. Sci. 2012, 26, 1213-1229. [CrossRef] 
1207. Mundler, P.; Rumpus, L. The energy efficiency of local food systems: A comparison between different modes of distribution. Food Policy 2012, 37, 609-615. [CrossRef]

1208. Post, A.; Mikkola, M. Nordic stakeholders in catering for sustainability. Br. Food J. 2012, 114, 743-761. [CrossRef]

1209. Tai, S. The Rise of U.S. Food Sustainability Litigation. South. Calif. Law Rev. 2012, 85, 1069-1135.

1210. Warbach, J.D.; Geith, C.; Sexton, A.; Kaneene, T. Eight areas of competency in decision making for sustainability in metro food systems. Transylvanian Rev. Adm. Sci. 2012, 145-157.

1211. Zhou, D.; An, P.; Pan, Z.; Zhang, F. Arable land use intensity change in China from 1985 to 2005: Evidence from integrated cropping systems and agro economic analysis. J. Agric. Sci. 2012, 150, 179-190. [CrossRef]

1212. Zhou, D.; Matsuda, H.; Hara, Y.; Takeuchi, K. Potential and observed food flows in a Chinese city: A case study of Tianjin. Agric. Human Values 2012, 29, 481-492. [CrossRef]

1213. Aiking, H. Future protein supply. Trends Food Sci. Technol. 2011, 22, 112-120. [CrossRef]

1214. Barlett, P.F. Campus Sustainable Food Projects: Critique and Engagement. Am. Anthropol. 2011, 113, 101-115. [CrossRef]

1215. Bean, M.; Sharp, J.S. Profiling alternative food system supporters: The personal and social basis of local and organic food support. Renew. Agric. Food Syst. 2011, 26, 243-254. [CrossRef]

1216. Bloom, J.D.; Hinrichs, C.C. Moving local food through conventional food system infrastructure: Value chain framework comparisons and insights. Renew. Agric. Food Syst. 2011, 26, 13-23. [CrossRef]

1217. Bush, S.R.; Duijf, M. Searching for (un)sustainabilty in pangasius aquaculture: A political economy of quality in European retail. Geoforum 2011, 42, 185-196. [CrossRef]

1218. DeLind, L.B. Are local food and the local food movement taking us where we want to go? Or are we hitching our wagons to the wrong stars? Agric. Human Values 2011, 28, 273-283. [CrossRef]

1219. Dunne, J.B.; Chambers, K.J.; Giombolini, K.J.; Schlegel, S.A. What does 'local' mean in the grocery store? Multiplicity in food retailers' perspectives on sourcing and marketing local foods. Renew. Agric. Food Syst. 2011, 26, 46-59. [CrossRef]

1220. Ervin, D.E.; Glenna, L.L.; Jussaume, R.A. The Theory and practice of genetically engineered crops and agricultural sustainability. Sustainability 2011, 3, 847-874. [CrossRef]

1221. Kremer, P.; DeLiberty, T.L. Local food practices and growing potential: Mapping the case of Philadelphia. Appl. Geogr. 2011, 31, 1252-1261. [CrossRef]

1222. McCune, N.M.; González, Y.R.; Alcántara, E.A.; Martínez, O.F.; Fundora, C.O.; Arzola, N.C.; Cairo, P.C.; D’Haese, M.; DeNeve, S.; Hernández, F.G. Global Questions, Local Answers: Soil Management and Sustainable Intensification in Diverse Socioeconomic Contexts of Cuba. J. Sustain. Agric. 2011, 35, 650-670. [CrossRef]

1223. McMichael, P. Food system sustainability: Questions of environmental governance in the new world (dis)order. Glob. Environ. Chang. 2011, 21, 804-812. [CrossRef]

1224. Medina, F.X. Food consumption and civil society: Mediterranean diet as a sustainable resource for the Mediterranean area. Public Health Nutr. 2011, 14, 2346-2349. [CrossRef] [PubMed]

1225. Melece, L. Sustainable Food: Issues of Food Security in Latvia. In Proceedings of the 12th International Scientific Conference on Economic Science for Rural Development, Jelgava, Latvia, 28-29 April 2011; Mazure, G., Ed.; Latvia University of Life Sciences and Technologies: Jelgava, Latvia, 2011; pp. 124-134.

1226. Metcalf, S.S.; Widener, M.J. Growing Buffalo's capacity for local food: A systems framework for sustainable agriculture. Appl. Geogr. 2011, 31, 1242-1251. [CrossRef]

1227. Phalan, B.; Balmford, A.; Green, R.E.; Scharlemann, J.P.W. Minimising the harm to biodiversity of producing more food globally. Food Policy 2011, 36, S62-S71. [CrossRef]

1228. Rojas, A.; Valley, W.; Mansfield, B.; Orrego, E.; Chapman, G.E.; Harlap, Y. Toward Food System Sustainability through School Food System Change: Think\&EatGreen@School and the Making of a Community-University Research Alliance. Sustainability 2011, 3, 763-788. [CrossRef]

1229. Sonnino, R.; McWilliam, S. Food waste, catering practices and public procurement: A case study of hospital food systems in Wales. Food Policy 2011, 36, 823-829. [CrossRef]

1230. Tansey, G. Whose power to control? Some reflections on seed systems and food security in a changing world. IDS Bull. 2011, 42, 111-120. [CrossRef]

1231. Thibert, J.; Badami, M.G. Estimating and communicating food system impacts: A case study in Montreal, Quebec. Ecol. Econ. 2011, 70, 1814-1821. [CrossRef]

1232. White, A.; Gallegos, D.; Hundloe, T. The impact of fresh produce specifications on the Australian food and nutrition system: A case study of the north Queensland banana industry. Public Health Nutr. 2011, 14, 1489-1495. [CrossRef]

1233. Adams, D.C.; Salois, M.J. Local versus organic: A turn in consumer preferences and willingness-to-pay. Renew. Agric. Food Syst. 2010, 25, 331-341. [CrossRef]

1234. Allen, P. Realizing justice in local food systems. Cambridge J. Reg. Econ. Soc. 2010, 3, 295-308. [CrossRef]

1235. Click, M.A.; Ridberg, R. Saving food: Food preservation as alternative food activism. Environ. Commun. 2010, 4, 301-317. [CrossRef]

1236. Condon, P.M.; Mullinix, K.; Fallick, A.; Harcourt, M. Agriculture on the edge: Strategies to abate urban encroachment onto agricultural lands by promoting viable human-scale agriculture as an integral element of urbanization. Int. J. Agric. Sustain. 2010, 8, 104-115. [CrossRef] 
1237. Cuellar, A.D.; Webber, M.E. An Updated Estimate for Energy Use in US Food Production and Policy Implications. In Proceedings of the ASME 4th International Conference on Energy Sustainability 2010, Phoenix, AZ, USA, 17-22 May 2010; American Society of Mechanical Engineers: New York, NY, USA, 2010; pp. 35-44.

1238. Gillespie, G.W. 2009 AFHVS presidential address: The steering question: Challenges to achieving food system sustainability. Agric. Hum. Values 2010, 27, 3-12. [CrossRef]

1239. Godfray, H.C.J.; Crute, I.R.; Haddad, L.; Lawrence, D.; Muir, J.F.; Nisbett, N.; Pretty, J.; Robinson, S.; Toulmin, C.; Whiteley, R. The future of the global food system. Philos. Trans. R. Soc. B Biol. Sci. 2010, 365, 2769-2777. [CrossRef]

1240. Howard, P.H.; Allen, P. Beyond organic and fair trade? An analysis of ecolabel preferences in the United States. Rural Sociol. 2010, 75, 244-269. [CrossRef]

1241. Kirschenmann, F. Alternative agriculture in an energy- and resource-depleting future. Renew. Agric. Food Syst. 2010, 25, 85-89. [CrossRef]

1242. Mikkola, M.; Risku-Norja, H.; Kurppa, S. Meta-Engineering Sustainable Food system by Panoramic Co-Configuration as a Developmental Tool. In Proceedings of the International Conference on Engineering and Meta-Engineering, Orlando, FL, USA, 6-9 April 2010; Baralt, J., Callaos, N., Chu, H., Ferrer, J., Tremante, A., Eds.; The International Institute of Informatics and Systemics: Orlando, FL, USA, 2010; pp. 190-195.

1243. Milestad, R.; Bartel-Kratochvil, R.; Leitner, H.; Axmann, P. Being close: The quality of social relationships in a local organic cereal and bread network in Lower Austria. J. Rural Stud. 2010, 26, 228-240. [CrossRef]

1244. Moore, S.R. Energy efficiency in small-scale biointensive organic onion production in Pennsylvania, USA. Renew. Agric. Food Syst. 2010, 25, 181-188. [CrossRef]

1245. Morgan, K. Local and green, global and fair: The ethical foodscape and the politics of care. SAGE J. 2010, $42,1852-1867$. [CrossRef]

1246. Morgan, K.; Sonnino, R. The urban foodscape: World cities and the new food equation. Cambridge J. Reg. Econ. Soc. 2010, 3 , 209-224. [CrossRef]

1247. Reilly, M.; Willenbockel, D. Managing uncertainty: A review of food system scenario analysis and modelling. Philos. Trans. R. Soc. B Biol. Sci. 2010, 365, 3049-3063. [CrossRef]

1248. Woeste, K.E.; Blanche, S.B.; Moldenhauer, K.A.; Nelson, C.D. Plant Breeding and Rural Development in the United States. Crop Sci. 2010, 50, 1625-1632. [CrossRef]

1249. Young, E.M. Deadly diets: Geographical reflections on the global food system. Geography 2010, 95, 60-69. [CrossRef]

1250. Alkon, A.H.; Norgaard, K.M. Breaking the Food Chains: An Investigation of Food Justice Activism. Sociol. Inq. 2009, 79, $289-305$. [CrossRef]

1251. Alpas, H.; Kiymaz, T. Food Security and Eco-terrorism Impacts on Environmental Security Through Vulnerabilities. In Proceedings of the NATO Advanced Research Workshop on International Regulation Implementation for Environmental Security in South Eastern Europe, Venice, Italy, 3-4 December 2009; Montini, M., Bogdanovic, S., Eds.; Springer: Dordrecht, Netherlands, 2009; pp. 137-150.

1252. Ferreira, M.V.; Jankowsky, M.; Nordi, N. History and Changes in a Fishermen Food System: A Community in Sao Paulo Coast, Brazil. Interciencia 2009, 34, 696-702.

1253. Fiscus, D.A. Comparative network analysis toward characterization of systemic organization for human-environmental sustainability. Ecol. Modell. 2009, 220, 3123-3132. [CrossRef]

1254. Fresco, L.O. Challenges for food system adaptation today and tomorrow. Environ. Sci. Policy 2009, 12, 378-385. [CrossRef]

1255. Huang, C.-T.; Richard, T.-Y.; Chang, S.-S. Crops and food security-experiences and perspectives from Taiwan. Asia Pac. J. Clin. Nutr. 2009, 18, 520-526.

1256. Komisar, J.; Nasr, J.; Gorgolewski, M. Designing for Food and Agriculture: Recent Explorations at Ryerson University. Open House Int. 2009, 34, 61-70. [CrossRef]

1257. Kurita, H.; Yokohari, M.; Bolthouse, J. The potential of intra-regional supply and demand of agricultural products in an urban fringe area: A case study of the Kanto Plain, Japan. Geogr. Tidsskr. J. Geogr. 2009, 109, 147-159. [CrossRef]

1258. Li, D.; Hu, X. Fish and its multiple human health effects in times of threat to sustainability and affordability: Are there alternatives? Asia Pac. J. Clin. Nutr. 2009, 18, 553-563. [PubMed]

1259. Loring, P.A.; Gerlach, S.C. Food, culture, and human health in Alaska: An integrative health approach to food security. Environ. Sci. Policy 2009, 12, 466-478. [CrossRef]

1260. Mikkola, M. Shaping professional identity for sustainability. Evidence in Finnish public catering. Appetite 2009, 53, 56-65. [CrossRef] [PubMed]

1261. Peters, C.J.; Bills, N.L.; Wilkins, J.L.; Fick, G.W. Foodshed analysis and its relevance to sustainability. Renew. Agric. Food Syst. 2009, 24, 1-7. [CrossRef]

1262. Schönhart, M.; Penker, M.; Schmid, E. Sustainable Local Food Production and Consumption. Outlook Agric. 2009, 38, 175-182. [CrossRef]

1263. Stroink, M.L.; Nelson, C.H. Aboriginal health learning in the forest and cultivated gardens: Building a nutritious and sustainable food system. J. Agromedicine 2009, 14, 263-269. [CrossRef]

1264. Thompson, J.; Scoones, I. Addressing the dynamics of agri-food systems: An emerging agenda for social science research. Environ. Sci. Policy 2009, 12, 386-397. [CrossRef] 
1265. Trauger, A. Social agency and networked spatial relations in sustainable agriculture. Area 2009, 41, 117-128. [CrossRef]

1266. Wallgren, C.; Höjer, M. Eating energy-Identifying possibilities for reduced energy use in the future food supply system. Energy Policy 2009, 37, 5803-5813. [CrossRef]

1267. Wezel, A.; Soldat, V. A quantitative and qualitative historical analysis of the scientific discipline of agroecology. Int. J. Agric. Sustain. 2009, 7, 3-18. [CrossRef]

1268. Yang, R.-Y.; Hanson, P.M. Improved food availability for food security in Asia-Pacific region. Asia Pac. J. Clin. Nutr. 2009, 18, 633-637.

1269. Allen, P. Mining for justice in the food system: Perceptions, practices, and possibilities. Agric. Hum. Values 2008, 25, 157-161. [CrossRef]

1270. Fonte, M. Knowledge, food and place. a way of producing, a way of knowing. Sociol. Rural. 2008, 48, 200-222. [CrossRef]

1271. Friel, S.; Marmot, M.; McMichael, A.J.; Kjellstrom, T.; Vågerö, D. Global health equity and climate stabilisation: A common agenda. Lancet 2008, 372, 1677-1683. [CrossRef]

1272. Fritz, M.; Schiefer, G. Food chain management for sustainable food system development: A European research agenda. Agribusiness 2008, 24, 440-452. [CrossRef]

1273. Guthman, J. Thinking inside the neoliberal box: The micro-politics of agro-food philanthropy. Geoforum 2008, 39, 1241-1253. [CrossRef]

1274. Islam, M.S. From pond to plate: Towards a twin-driven commodity chain in Bangladesh shrimp aquaculture. Food Policy 2008, 33, 209-223. [CrossRef]

1275. Lowe, P.; Phillipson, J.; Lee, R.P. Socio-technical innovation for sustainable food chains: Roles for social science. Trends Food Sci. Technol. 2008, 19, 226-233. [CrossRef]

1276. Mariola, M.J. The local industrial complex? Questioning the link between local foods and energy use. Agric. Human Values 2008, 25, 193-196. [CrossRef]

1277. Wahlqvist, M.L. National food fortification: A dialogue with reference to Asia: Policy in evolution. Asia Pac. J. Clin. Nutr. 2008, $17,24-29$.

1278. Åsebø, K.; Jervell, A.M.; Lieblein, G.; Svennerud, M.; Francis, C. Farmer and consumer attitudes at farmers markets in Norway. J. Sustain. Agric. 2007, 30, 67-93. [CrossRef]

1279. Friedmann, H. Scaling up: Bringing public institutions and food service corporations into the project for a local, sustainable food system in Ontario. Agric. Human Values 2007, 24, 389-398. [CrossRef]

1280. Harmon, A.H.; Gerald, B.L. Position of the american dietetic association: Food and nutrition professionals can implement practices to conserve natural resources and support ecological sustainability. J. Am. Diet. Assoc. 2007, 107, 1033-1043. [CrossRef]

1281. Ilbery, B.; Maye, D. Marketing sustainable food production in Europe: Case study evidence from two Dutch labelling schemes. Tijdschr. voor Econ. en Soc. Geogr. 2007, 98, 507-518. [CrossRef]

1282. McKay, J. Food industry \& economic development in the Asia Pacific. Asia Pac. J. Clin. Nutr. 2007, 16, 80-84.

1283. Parr, D.M.; Trexler, C.J.; Khanna, N.R.; Battisti, B.T. Designing sustainable agriculture education: Academics' suggestions for an undergraduate curriculum at a land grant university. Agric. Human Values 2007, 24, 523-533. [CrossRef]

1284. Rojas, A.; Richer, L.; Wagner, J. University of British Columbia food system project: Towards sustainable and secure campus food systems. Ecohealth 2007, 4, 86-94. [CrossRef]

1285. Schmid, M.; Salomeyesudas, B.; Satheesh, P.; Hanley, J.; Kuhnlein, H. Intervention with traditional food as a major source of energy, protein, iron, vitamin C and vitamin A for rural Dalit mothers and young children in Andhra Pradesh, South India. Asia Pac. J. Clin. Nutr. 2007, 16, 84-93.

1286. Allen, P.; Guthman, J. From "old school" to "farm-to-school": Neoliberalization from the ground up. Agric. Human Values 2006, 23, 401-415. [CrossRef]

1287. Fraser, E.D.G. Food system vulnerability: Using past famines to help understand how food systems may adapt to climate change. Ecol. Complex. 2006, 3, 328-335. [CrossRef]

1288. Harmon, A.H.; Maretzki, A.N. Assessing Food System Attitudes Among Youth: Development and Evaluation of Attitude Measures. J. Nutr. Educ. Behav. 2006, 38, 91-95. [CrossRef] [PubMed]

1289. Kriflik, L. Consumer citizenship: Acting to minimise environmental health risks related to the food system. Appetite 2006, 46, 270-279. [CrossRef] [PubMed]

1290. Morris, C.; Kirwan, J. Vegetarians: Uninvited, uncomfortable or special guests at the table of the alternative food economy? Sociol. Rural. 2006, 46, 192-213. [CrossRef]

1291. Wright, D.W. Civic engagement through civic agriculture: Using food to link classroom and community. Teach. Sociol. 2006, 34, 224-235.

1292. Barton, A.; Koch, P.; Contento, I.; Hagiwara, S. From global Sustainability to inclusive education: Understanding urban children's ideas about the food system. Int. J. Sci. Educ. 2005, 27, 1163-1186. [CrossRef]

1293. Buttel, F.H. Ever since hightower: The politics of agricultural research activism in the molecular age. Agric. Human Values 2005, 22, 275-283. [CrossRef]

1294. Johnston, J.; Baker, L. Eating outside the box: FoodShare's good food box and the challenge of scale. Agric. Human Values 2005, 22, 313-325. [CrossRef]

1295. Kriflik, L.S.; Yeatman, H. Food scares and sustainability: A consumer perspective. Health. Risk Soc. 2005, 7, 11-24. [CrossRef] 
1296. Lozier, J.; Rayburn, E.; Shaw, J. Growing and selling pasture-finished beef: Results of a Nationwide Survey. J. Sustain. Agric. 2005, 25, 93-112. [CrossRef]

1297. Natarajan, S.; Renczesova, V.; Kukuckova, M.; Stuchlik, S.; Turna, J. Genetically modified organisms from the point of view of horizontal gene transfer. Biologia 2005, 60, 633-639.

1298. Ostrom, M.; Jackson-Smith, D. Defining a Purpose: Diverse Farm Constituencies and Publicly Funded Agricultural Research and Extension. J. Sustain. Agric. 2005, 27, 57-76. [CrossRef]

1299. Pingali, P.; Alinovi, L.; Sutton, J. Food Security in Complex Emergencies: Enhancing Food System Resilience. Disasters 2005, 29, S5-S24. [CrossRef]

1300. Sundkvist, Å.; Milestad, R.; Jansson, A. On the importance of tightening feedback loops for sustainable development of food systems. Food Policy 2005, 30, 224-239. [CrossRef]

1301. Winne, M. Education for Change. J. Agric. Environ. Ethics 2005, 18, 305-310. [CrossRef]

1302. Clancy, K. Potential Contributions of Planning to Community Food Systems. J. Plan. Educ. Res. 2004, 23, 435-438. [CrossRef]

1303. Kratochvil, R.; Kaltenecker, M.; Freyer, B. The ability of organic farming to nourish the Austrian people: An empirical study in the region Mostviertel-Eisenwurzen (A). Renew. Agric. Food Syst. 2004, 19, 47-56. [CrossRef]

1304. Pothukuchi, K. Community Food Assessment. J. Plan. Educ. Res. 2004, 23, 356-377. [CrossRef]

1305. Stonehouse, D.P. Sustainability Issues in the Agri-Food Sector in Ontario, Canada. J. Sustain. Agric. 2004, 23, 109-124. [CrossRef]

1306. Vallianatos, M.; Gottlieb, R.; Haase, M.A. Farm-to-School. J. Plan. Educ. Res. 2004, 23, 414-423. [CrossRef]

1307. Hassanein, N. Practicing food democracy: A pragmatic politics of transformation. J. Rural Stud. 2003, 19, 77-86. [CrossRef]

1308. Heller, M.C.; Keoleian, G.A. Assessing the sustainability of the US food system: A life cycle perspective. Agric. Syst. 2003, 76, 1007-1041. [CrossRef]

1309. Hollander, G.M. Re-naturalizing sugar: Narratives of place, production and consumption. Soc. Cult. Geogr. 2003, 4, 59-74. [CrossRef]

1310. Pelletier, D.; McCullum, C.; Kraak, V.; Asher, K. Participation, power and beliefs shape local food and nutrition policy. J. Nutr. 2003, 133, 301-304. [CrossRef]

1311. Peters, C.J.; Fick, G.W.; Wilkins, J.L. Cultivating Better Nutrition: Can the Food Pyramid Help Translate Dietary Recommendations into Agricultural Goals? Agron. J. 2003, 95, 1424-1431. [CrossRef]

1312. Hendrickson, M.K.; Heffernan, W.D. Opening Spaces through Relocalization: Locating Potential Resistance in the Weaknesses of the Global Food System. Sociol. Rural. 2002, 42, 347-369. [CrossRef]

1313. Stuthman, D. Contribution of durable disease resistance to sustainable agriculture. Euphytica 2002, 124, 253-258. [CrossRef]

1314. Wilkins, J.L.; Bowdish, E.; Sobal, J. Consumer perceptions of seasonal and local foods: A study in a U.S. community. Ecol. Food Nutr. 2002, 41, 415-439. [CrossRef]

1315. Francis, C.A.; Carter, H.C. Participatory education for sustainable agriculture: Everyone a teacher, everyone a learner. J. Sustain. Agric. 2001, 18, 71-83. [CrossRef]

1316. Shanklin, C.W.; Hackes, B.L. Position of the american dietetic association: Dietetics professionals can implement practices to conserve natural resources and protect the environment. J. Am. Diet. Assoc. 2001, 101, 1221-1227. [CrossRef]

1317. Berge, E. Advancement by the integration of elementary improvements into superior systems. J. Agric. Eng. Res. 2000, 76, 277-283. [CrossRef]

1318. Combs, G.F. Food system-based approaches to improving micronutrient nutrition: The case for selenium. BioFactors 2000, 12, 39-43. [CrossRef]

1319. Kloppenburg, J., Jr.; Lezberg, S.; De Master, K.; Stevenson, G.; Hendrickson, J. Tasting food, tasting sustainability: Defining the attributes of an alternative food system with competent, ordinary people. Hum. Organ. 2000, 59, 177-186. [CrossRef]

1320. La Trobe, H.L.; Acott, T.G. Localising the global food system. Int. J. Sustain. Dev. World Ecol. 2000, 7, 309-320. [CrossRef]

1321. Lyson, T.A.; Green, J. The agricultural marketscape: A framework for sustaining agriculture and communities in the Northeast. J. Sustain. Agric. 1999, 15, 133-150. [CrossRef]

1322. Sumberg, J. The Dar es Salaam Milk System: Dynamics of change and sustainability. Habitat Int. 1999, 23, 189-200. [CrossRef]

1323. Welch, R.M.; Graham, R.D. A new paradigm for world agriculture: Meeting human needs. F. Crop. Res. 1999, 60, 1-10. [CrossRef]

1324. Hill, S.B. Redesigning agroecosystems for environmental sustainability: A deep systems approach. Syst. Res. Behav. Sci. 1998, 15, 391-402. [CrossRef]

1325. Hollander, G.M. Agroenvironmental conflict and world food system theory: Sugarcane in the Everglades Agricultural Area. J. Rural Stud. 1995, 11, 309-318. [CrossRef]

1326. Bender, W.H. An end use analysis of global food requirements. Food Policy 1994, 19, 381-395. [CrossRef] 